
Tanuary 1946

\title{
EXTRACTION OF ALUMINA FROM CLAYS AND HIGH-SILICA BAUXITES
}

\author{
By E. P. Flint, W. F. Clarke, E. S. Newman, Leo Shartsis, D. L. Bishop, and \\ Lansing S. Wells
}

ABSTRACT

Two processes for extracting alumina from low-grade ores are described, one applicable to both clays and high-silica bauxites, and the other only to bauxites. In the former process, a line-containing sinter is prepared and annealed by cooling it slowly through the range of $1,300^{\circ}$ to $1,200^{\circ} \mathrm{C}$. The annealed sinter dusts to a powder which requires no grinding. This material is extracted with a solution containing about $200 \mathrm{~g}$ of $\mathrm{Na}_{2} \mathrm{CO}_{3}$ and $150 \mathrm{~g}$ of $\mathrm{NaCl} /$ liter, and an extract is obtained in which the concentration of $\mathrm{Al}_{2} \mathrm{O}_{3}$ is 70 to $80 \mathrm{~g} /$ liter and that of $\mathrm{SiO}_{2}$, 1 to $2 \mathrm{~g} /$ liter. By boiling the extract with a seed charge of synthetic sodalite, $3 \mathrm{Na}_{2} \mathrm{O} \cdot 3 \mathrm{Al}_{2} \mathrm{O}_{3} \cdot 6 \mathrm{SiO}_{2} \cdot 2 \mathrm{NaCl}$, its silica content is reduced to 0.1 percent of the alumina content or less. Alumina, suitable for the manufacture of aluminum by electrolytic reduction, is precipitated by passing carbon dioxide into the desilicated solution. About 95 percent of the alumina in the clay is recovered by this method.

The other process developed in this investigation involves the extraction of alumina from high-silica bauxites with sodium hydroxide-sodium chloride solution and recovery of soda and alumina from the residues by a modified sodalime-sinter method. Recoveries in excess of 90 percent of the alumina in high-silica bauxites are obtained.

In cyclical operation of each process, the spent solution from the aluminaprecipitation step is used in the treatment of a fresh batch of material.

When the bauxites are extracted with solutions containing mixtures of sodium hydroxide and sodium carbonate, sodium sulfate, sodium bromide, or sodium nitrate, the quantities of silica present in the extracts are lower, the higher the concentration of the salt. This is caused by the formation and increased stabilization of slightly soluble compounds related to sodalite. Comparisons of the $\mathrm{X}$-ray diffraction patterns of various sodalite type compounds are presented. By the extraction of bauxite with sodium hydroxide solution, in the absence of added salts, a relatively soluble hydrated nephelite, $\mathrm{Na}_{2} \mathrm{O} \cdot \mathrm{Al}_{2} \mathrm{O}_{3} \cdot 2 \mathrm{SiO}_{2} \cdot 2 \mathrm{H}_{2} \mathrm{O}$, is formed, which has a crystal structure different from that of sodalite.

\section{CONTENTS}

I. Introduction

II. Extraction of alumina from high-silica bauxites with sodium hydroxidesalt solutions

1. Materials and general procedure

2. Preliminary experiments.

3. Studies of sodalite-type compounds and of bauxite-extraction residues...

4. Comparison of the effectiveness of various salts in depressing the concentration of silica in sodium aluminate solutions...-

5. Pilot-plant extractions

6 . Recovery of soda and alumina from bauxite-extraction residues.

7. Flow sheet and summary of process 


\section{CONTENTS-Continued}

III. Extraction of alumina from clay by the lime-sinter process__. 80

1. Materials and procedure

2. Preparation of sinters

3. Extraction of sinters with dilute sodium carbonate solutions_.- 82

4. Desilication of dilute sodium aluminate solutions _._.

5. Extraction of sinters with concentrated sodium carbonate solutions

6. Annealing of sinters

7. Extraction of annealed sinters with concentrated sodium carbonate solutions _. 93

8. Desilication of concentrated sodium aluminate solutions_._. 98

9. Theory of sodalite desilication

10. Flow sheet and summary of process

IV. Extraction of alumina from high-silica bauxites by the lime-sinter

process_. _.

1. Materials

2. Procedure, results, and discussion

V. Possible commercial significance of methods

VI. References_.

\section{INTRODUCTION}

The object of the investigations was to develop alkaline processes, of possible commercial application, for the extraction of alumina from clays and high-silica bauxites.

In the extraction of alumina from an ore as sodium aluminate there are three principal methods: (1) Direct extraction of the untreated ore with sodium hydroxide solution, as in the Bayer process. $[1]^{1} ;$ (2) treatment of the ore to give a product containing solid sodium aluminate, which is extracted with water; and (3) treatment of the ore to give a product containing calcium aluminate, which can be decomposed with sodium carbonate.

The first part of this paper deals with the extraction of alumina from high-silica bauxites by a combination of methods (1) and (2). The remainder of the report is concerned with the extraction of alumina from clays and high-silica bauxites by method (3) used as a modified lime-sinter process. In the three methods developed at the National Bureau of Standards, the final disilication is effected by the formation of the very slighlty soluble compound sodalite, $3 \mathrm{Na}_{2} \mathrm{O} .3 \mathrm{Al}_{2} \mathrm{O}_{3} .6 \mathrm{SiO}_{2} .2 \mathrm{NaCl}$.

\section{EXTRACTION OF ALUMINA FROM HIGH-SILICA BAUXITES WITH SODIUM HYDROXIDE-SALT SOLU- TIONS}

\section{MATERIALS AND GENERAL PROCEDURE}

Four bauxites of compositions given in table 1, ground to such fineness that 80 to 90 percent passed a No. 200 sieve, were chosen for extraction. Other materials used included sodium hydroxide, sodium carbonate, sodium sulfate, sodium bromide, sodium chloride, and sodium nitrate.

The procedure followed in most experiments involved boiling or autoclaving the finely ground bauxite with 100 to $400 \mathrm{ml}$ of a sodium hydroxide solution containing various proportions of sodium salts.

\footnotetext{
1 Figures in brackets indicate the literature references at the end of this paper.
} 
The experiments at boiling temperatures were made in iron containers fitted with reflux condensers, and those at $150^{\circ} \mathrm{C}$ in a bomb-type autoclave having a capacity of 1 liter. After a heating period of 1 to 3 hours, the residues were separated from the solutions by filtration and repulped at boiling temperature with $100-\mathrm{ml}$ portions of water. Each residue was then washed on the filter with $100 \mathrm{ml}$ of hot water and the combined extracts and washes made up to 1 liter in volumetric flasks. Analyses for silica were made by dehydration with sulfuric acid of aliquots large enough to contain 5 to $10 \mathrm{~g}$ of alumina. Alumina was determined in the filtrates from the silica determinations. In some cases the approximate concentrations of sodium hydroxide and carbonate in the extracts were determined by titration of aliquots with standard acid.

TABLE 1.-Composition of bauxites

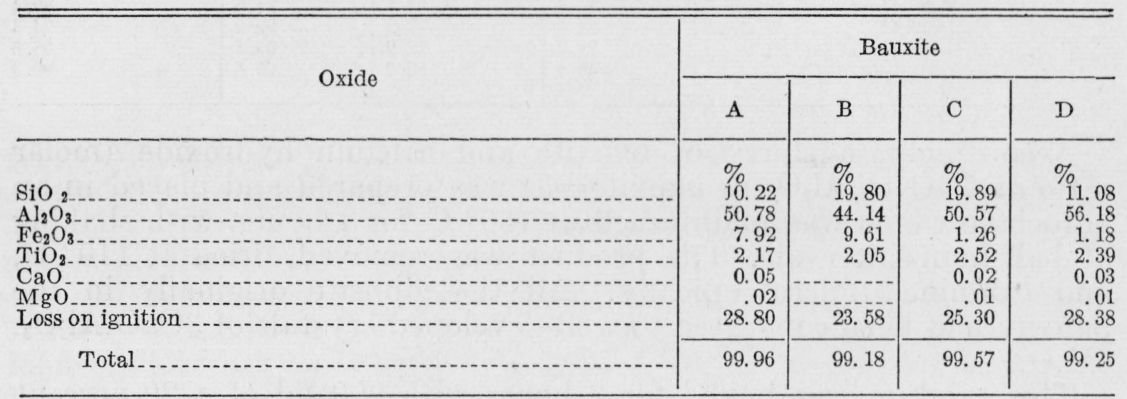

Extractions of the bauxites were made on both a laboratory and small pilot-plant scale. The solid residues from the pilot-plant extractions were dried, analyzed, and further treated to recover the alumina and soda they contained. This treatment consisted in mixing the residues with calcium carbonate, heating to suitable temperatures, and extracting the ground products with water or various alkaline solutions.

Studies were made of the structures, as revealed by X-ray diffraction patterns, and of the compositions of the solid residues remaining after extraction of the bauxites with sodium hydroxide solution alone and when various sodium salts were present. Synthetic preparations consisting of the various sodium salts were also investigated and compared with the residues from the extractions of the bauxites.

\section{PRELIMINARY EXPERIMENTS}

Because of an extensive background of research in this laboratory on the preparation and properties of the calcium aluminates and silicates [2], it was decided to investigate the recovery of alumina from various calcium aluminates. For this purpose quantities of $3 \mathrm{CaO} \cdot \mathrm{Al}_{2} \mathrm{O}_{3}, 5 \mathrm{CaO} .3 \mathrm{Al}_{2} \mathrm{O}_{3}, \mathrm{CaO} \cdot \mathrm{Al}_{2} \mathrm{O}_{3}$, and isometric hydrated tricalcium aluminate, $3 \mathrm{CaO} \cdot \mathrm{Al}_{2} \mathrm{O}_{3} \cdot 6 \mathrm{H}_{2} \mathrm{O}$, prepared by the usual methods [3], were available. The preparations were ground to pass a No. 200 sieve, and 2-g samples were extracted for 2 hours with 100 -ml portions of a solution containing $50 \mathrm{~g}$ of $\mathrm{Na}_{2} \mathrm{CO}_{3}$ per liter. The results of extractions of alumina at $25^{\circ} \mathrm{C}, 50^{\circ} \mathrm{C}, 85^{\circ} \mathrm{C}$, and at boiling are given 
in table 2. In making the extractions, mechanical stirring was employed at temperatures below boiling.

Because the hydrated calcium aluminate gave an appreciably better extraction than any of the anhydrous compounds, the possibility suggested itself of forming $3 \mathrm{CaO} \cdot \mathrm{Al}_{2} \mathrm{O}_{3} \cdot 6 \mathrm{H}_{2} \mathrm{O}$ from a mixture of bauxite and lime, for the purpose of subsequent extraction with sodium carbonate solution.

TABLE 2.-Extraction of alumina from calcium aluminates

[Extraction for 2 hours of 2-g samples, ground to pass No. 200 sieve, with $100 \mathrm{ml}$ of sodium carbonate solution containing 5-g of $\mathrm{Na}_{2} \mathrm{CO}_{3}$. Mechanical stirring was used at temperatures below boiling]

\begin{tabular}{|c|c|c|c|c|c|}
\hline \multirow{2}{*}{ Experiment } & \multirow{2}{*}{ Temperature } & \multicolumn{4}{|c|}{ Recovery of $\mathrm{Al}_{2} \mathrm{O}_{3}$ from- } \\
\hline & & $3 \mathrm{CaO} \cdot \mathrm{Al}_{2} \mathrm{O}_{3}$ & $5 \mathrm{CaO} .3 \mathrm{Al}_{2} \mathrm{O}_{3}$ & $\mathrm{CaO} \cdot \mathrm{Al}_{2} \mathrm{O}_{3}$ & $3 \mathrm{CaO} \cdot \mathrm{Al}_{2} \mathrm{O}_{3} \cdot 6 \mathrm{H}_{2} \mathrm{O}$ \\
\hline 1. & $\begin{array}{l}25^{\circ} \mathrm{C} \\
50^{\circ} \mathrm{C} \\
85^{\circ} \mathrm{C}- \\
\text { Boiling }\end{array}$ & $\begin{array}{l}33.8 \\
27.5 \\
28.7 \\
46.4\end{array}$ & $\begin{array}{l}66.1 \\
77.2 \\
72.9 \\
82.2\end{array}$ & $\begin{array}{l}84.6 \\
92.2 \\
95.5 \\
95.6\end{array}$ & $\begin{array}{l}89.4 \\
94.3 \\
98.6 \\
99.3\end{array}$ \\
\hline
\end{tabular}

Accordingly, a slurry of bauxite and calcium hydroxide (molar ratio of $\mathrm{CaO}$ to $\mathrm{Al}_{2} \mathrm{O}_{3}$ in bauxite $=3$ ) was prepared and placed in an autoclave which was maintained at $150^{\circ} \mathrm{C}$ for 4 hours, with shaking at half-hour intervals. The product was removed, dried at $110^{\circ} \mathrm{C}$, and examined microscopically. All the gibbsite originally in the bauxite had been converted to well-developed crystals of $3 \mathrm{CaO} \cdot \mathrm{Al}_{2} \mathrm{O}_{3}$. $6 \mathrm{H}_{2} \mathrm{O}$.

This product was boiled for 3 hours with $200 \mathrm{ml}$ of a 20-percent $\mathrm{Na}_{2} \mathrm{CO}_{3}$ solution and filtered (experiment 1, table 3). Similar extractions with 20- and 30-percent $\mathrm{Na}_{2} \mathrm{CO}_{3}$ solutions were made of mixtures of the same quantities of $\mathrm{Ca}(\mathrm{OH})_{2}$ and bauxite that had not been previously autoclaved. Sodium hydroxide extractions were also made of the bauxite with no added $\mathrm{Ca}(\mathrm{OH})_{2}$. In all the experiments the quantity of material treated was equivalent to $58 \mathrm{~g}$ of bauxite per liter of solution.

TABLE 3.-Recovery of alumina from bauxite $A$ under various conditions

The quantity of material extracted was equivalent to $58 \mathrm{~g}$ of bauxite $\mathrm{A}$ ( $29.5 \mathrm{~g}$ of $\mathrm{Al}_{2} \mathrm{O}_{3}$ ) per liter of solution ${ }^{\circ}$ The extraction mixtures were boiled for $3 \mathrm{hr}$ before filtering].

\begin{tabular}{|c|c|c|c|c|c|c|c|}
\hline \multirow{2}{*}{$\begin{array}{l}\text { Experi- } \\
\text { ment }\end{array}$} & \multirow{2}{*}{ Mix } & \multirow{2}{*}{$\begin{array}{c}\text { Molar ratio } \\
\mathrm{CaO} / \mathrm{Al}_{2} \mathrm{O}_{3} \\
\text { in mix }\end{array}$} & \multirow{2}{*}{$\begin{array}{l}\text { Autoclave } \\
\text { treatment of } \\
\text { mix prior to } \\
\text { extraction }\end{array}$} & \multicolumn{2}{|c|}{$\begin{array}{l}\text { Composition of ex- } \\
\text { tracting solution }\end{array}$} & \multirow{2}{*}{$\begin{array}{l}\text { Recovery } \\
\text { of } \mathrm{Al}_{2} \mathrm{O}_{3}\end{array}$} & \multirow{2}{*}{ 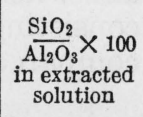 } \\
\hline & & & & $\mathrm{Na}_{2} \mathrm{CO}_{3}$ & NaOH & & \\
\hline $\begin{array}{l}1 \\
2 \\
4 \\
5\end{array}$ & $\begin{array}{c}\text { Lime+bauxite } \\
\text { Bauxite only } \\
\text { do do } \\
\text { do }\end{array}$ & $\begin{array}{l}3 \\
3 \\
3 \\
0 \\
0 \\
0\end{array}$ & $\begin{array}{l}4 \mathrm{hr} \text { at } 150^{\circ} \mathrm{C} . \\
\mathrm{None}\end{array}$ & $\begin{array}{r}\text { g/liter } \\
200 \\
200 \\
300 \\
0 \\
0 \\
0\end{array}$ & $\begin{array}{r}\text { g/liter } \\
0 \\
0 \\
0 \\
74 \\
200 \\
300\end{array}$ & $\begin{array}{r}\% \\
81 \\
81 \\
71 \\
77 \\
81 \\
83\end{array}$ & $\begin{array}{r}0.58 \\
.52 \\
.20 \\
1.29 \\
1.33 \\
1.44\end{array}$ \\
\hline
\end{tabular}

Comparison of experiments 1 and 2, table 3, shows that there is no advantage in forming the tricalcium aluminate hydrate by preliminary autoclaving of the lime-bauxite mixture. It may be noted that there was less silica in the extracts in experiments 1 to 3 than in 4 to 6 . In the first three experiments sufficient lime was present to convert 
$100 \mathrm{~g}$ of $\mathrm{Na}_{2} \mathrm{CO}_{3}$ per liter to $74 \mathrm{~g}$ of $\mathrm{NaOH}$ per liter on complete causticization, leaving $100 \mathrm{~g}$ of $\mathrm{Na}_{2} \mathrm{CO}_{3}$ per liter in excess in experiments 1 and 2 , and $200 \mathrm{~g}$ of $\mathrm{Na}_{2} \mathrm{CO}_{3}$ per liter in excess in experiment 3 . It appears that an increase in $\mathrm{Na}_{2} \mathrm{CO}_{3}$ is accompanied by a decrease in the concentration of silica in the extracts. This observation is in agreement with a statement by Pesin and Lileev [4] that sodium aluminate solutions can be desilicated by heating them in the presence of high concentrations of sodium carbonate.

Two series of extractions were made of bauxites B, C, and D with solutions containing mixtures of $\mathrm{Na}_{2} \mathrm{CO}_{3}$ and $\mathrm{NaOH}$ (tables 4 and 5). The purpose of the first series was to determine the molar ratios of the $\mathrm{Na}_{2} \mathrm{O}$ (added as $\mathrm{NaOH}$ ) ${ }^{2}$ in the solution to the $\mathrm{Al}_{2} \mathrm{O}_{3}$ in the bauxites, that would dissolve the maximum quantities of alumina at the boiling temperatures of the solutions. In these experiments the volume of the extracting solution was $200 \mathrm{ml}$.

TABLE 4.-Determination of optimum molar ratios of $\mathrm{Na}_{2} \mathrm{O}$ (as $\mathrm{NaOH}$ ) in extracting solution to $\mathrm{Al}_{2} \mathrm{O}_{3}$ in bauxites ${ }^{\text {a }}$

\begin{tabular}{|c|c|c|c|c|c|c|c|c|c|}
\hline \multirow{3}{*}{ Experiment } & \multirow{3}{*}{$\begin{array}{l}\text { Baux- } \\
\text { ite } \\
\text { desig- } \\
\text { nation }\end{array}$} & \multirow{3}{*}{$\begin{array}{l}\text { Quan- } \\
\text { tity of } \\
\text { baux- } \\
\text { ite } \\
\text { used }\end{array}$} & \multicolumn{6}{|c|}{ Composition of solutions } & \multirow{3}{*}{$\begin{array}{c}\mathrm{Al}_{2} \mathrm{O}_{3} \\
\text { ex- } \\
\text { tracted }\end{array}$} \\
\hline & & & \multicolumn{3}{|c|}{ Initial } & \multicolumn{3}{|c|}{ Final } & \\
\hline & & & $\mathrm{Na}_{2} \mathrm{CO}_{3}$ & $\mathrm{NaOH}$ & $\begin{array}{c}\mathrm{Molar} \\
\text { ratio } \mathrm{Na}_{2} \mathrm{O} \\
\text { (as } \mathrm{NaOH} \text { ): } \\
\mathrm{Al}_{2} \mathrm{O}_{3} \text { in } \\
\text { bauxite }\end{array}$ & $\mathrm{Na}_{2} \mathrm{CO}_{3}$ & $\mathrm{NaOH}$ & $\mathrm{Al}_{2} \mathrm{O}_{3}$ & \\
\hline & $\begin{array}{l}\mathrm{B} \\
\mathrm{B} \\
\mathrm{B} \\
\mathrm{B} \\
\mathrm{C}\end{array}$ & $\begin{array}{c}\text { g/liter } \\
289 \\
241 \\
144 \\
96.5 \\
252.5\end{array}$ & $\begin{array}{r}\text { g/liter } \\
300 \\
300 \\
300 \\
300 \\
300\end{array}$ & $\begin{array}{r}\text { g/liter } \\
100 \\
100 \\
100 \\
100 \\
100\end{array}$ & $\begin{array}{l}\text { 1. } 0 \\
1.2 \\
2.0 \\
\text { 3. } 0 \\
1.0\end{array}$ & $\begin{array}{r}\text { g/liter } \\
256.5 \\
263.0 \\
278.0 \\
286.8 \\
259.5\end{array}$ & $\begin{array}{r}\text { g/liter } \\
84.5 \\
94.5 \\
88.5 \\
88.5 \\
86.5\end{array}$ & $\begin{array}{r}\text { g/liter } \\
39.3 \\
47.3 \\
39.9 \\
26.8 \\
52.7\end{array}$ & $\begin{array}{ll}\% & \\
3 \\
4 \\
6 \\
6 \\
\\
4\end{array}$ \\
\hline $\begin{array}{l}6 \\
7 \\
8 \\
9 \\
10\end{array}$ & $\begin{array}{l}\mathrm{C} \\
\mathrm{C} \\
\mathrm{C} \\
\mathrm{D} \\
\mathrm{D}\end{array}$ & $\begin{array}{l}168 \\
126 \\
84 \\
284 \\
189.5\end{array}$ & $\begin{array}{l}300 \\
300 \\
300 \\
250 \\
250\end{array}$ & $\begin{array}{l}100 \\
100 \\
100 \\
125 \\
125\end{array}$ & $\begin{array}{l}1.5 \\
2.0 \\
3.0 \\
1.0 \\
1.5\end{array}$ & $\begin{array}{l}278.0 \\
278.0 \\
267.5 \\
231.5 \\
221.0\end{array}$ & $\begin{array}{r}77.0 \\
88.5 \\
94.5 \\
114.0 \\
121.5\end{array}$ & $\begin{array}{l}55.8 \\
42.3 \\
28.9 \\
64.1 \\
81.3\end{array}$ & $\begin{array}{l}6 \\
6 \\
68 \\
4 \\
7\end{array}$ \\
\hline 11 & $\begin{array}{l}\mathrm{D} \\
\mathrm{D}\end{array}$ & $\begin{array}{c}142 \\
94.5\end{array}$ & $\begin{array}{l}250 \\
250\end{array}$ & $\begin{array}{l}125 \\
125\end{array}$ & $\begin{array}{l}\text { 2. } 0 \\
3.0\end{array}$ & $\begin{array}{l}234.0 \\
229.5\end{array}$ & $\begin{array}{l}117.0 \\
120.5\end{array}$ & $\begin{array}{l}61.1 \\
41.8\end{array}$ & $\begin{array}{l}7 \\
7\end{array}$ \\
\hline
\end{tabular}

axtracted by boiling for $3 \mathrm{hr}$.

based on original volume of extracting solution $(200 \mathrm{ml})$.

Figure 1 shows the relationships between the percentages of $\mathrm{Al}_{2} \mathrm{O}_{3}$ dissolved from the bauxites and the molar ratios of $\mathrm{Na}_{2} \mathrm{O}$ in the initial solutions to $\mathrm{Al}_{2} \mathrm{O}_{3}$ in the bauxites. It is evident that, at boiling temperatures, only very slight increases in the extraction of $\mathrm{Al}_{2} \mathrm{O}_{3}$ occur at molar ratios above 2.0 .

It should be noted (table 4) that the concentrations of both $\mathrm{Na}_{2} \mathrm{CO}_{3}$ and $\mathrm{NaOH}$ remaining in solution are less than those initially present. This indicates that the solid residues must contain carbonate as well as $\mathrm{Na}_{2} \mathrm{O}$ derived from both $\mathrm{NaOH}$ and $\mathrm{Na}_{2} \mathrm{CO}_{3}$.

A second series of extractions of the bauxites was made, both at boiling temperatures and $150^{\circ} \mathrm{C}$, with solutions containing $125 \mathrm{~g}$ of $\mathrm{NaOH}$ per liter and various amounts of $\mathrm{Na}_{2} \mathrm{CO}_{3}$ as shown in table 5 .

\footnotetext{
${ }^{2}$ Here and subsequently in the text, in the tables, and in figure 1, the designation $\mathrm{Na}_{2} \mathrm{O}$ is intended to 2 Here and subsequently in the text, in the tables, and in figure 1 , the designation $\mathrm{Na}_{2} \mathrm{O}$ is intended to
indicate the sodium hydroxide added to the mixtures as such, and does not include sodium hydroxide that may be formed by the partial hydrolysis of sodium carbonate.
} 
The actual volume of the solutions used in the experiments was $400 \mathrm{ml}$, and the quantities of bauxite were such that the molar ratio of $\mathrm{Na}_{2} \mathrm{O}$ (as $\mathrm{NaOH}$ ) in the initial solutions to $\mathrm{Al}_{2} \mathrm{O}_{3}$ in the bauxites was 2.0. As before, the concentrations of $\mathrm{Al}_{2} \mathrm{O}_{3}$ and $\mathrm{SiO}_{2}$ in the extracts are calculated on the basis of the original volume of the solutions and expressed in grams per liter.

The concentration of $\mathrm{SiO}_{2}$ in the extracts is shown (in table 5) to decrease with increase in the $\mathrm{Na}_{2} \mathrm{CO}_{3}$ in the solutions, thus confirming

TABLE 5.-Extractions of bauxites with solutions containing $125 \mathrm{~g}$ of sodium hydroxide per liter and various amounts of sodium carbonate

\begin{tabular}{|c|c|c|c|c|c|c|c|c|}
\hline Experiment & $\begin{array}{c}\text { Bauxite } \\
\text { desig- } \\
\text { nation }\end{array}$ & $\begin{array}{l}\text { Quan- } \\
\text { tity of } \\
\text { bauxite } \\
\text { used }\end{array}$ & $\begin{array}{c}\mathrm{Na}_{2} \mathrm{CO}_{3} \\
\text { in extract- } \\
\text { ing solu- } \\
\text { tion }\end{array}$ & Temperature & $\begin{array}{c}\mathrm{Al}_{2} \mathrm{O}_{3} \\
\text { in solu- } \\
\text { tion }\end{array}$ & $\begin{array}{c}\mathrm{SiO}_{2} \\
\text { in solu- } \\
\text { tion }\end{array}$ & $\begin{array}{l}\text { Extrac- } \\
\text { tion of } \\
\mathrm{Al}_{2} \mathrm{O}_{3} b\end{array}$ & $\begin{array}{l}\frac{\mathrm{SiO}_{2}}{\mathrm{Al}_{2} \mathrm{O}_{3}} \times 100 \\
\text { in solution }\end{array}$ \\
\hline $\begin{array}{l}1 \\
1 \\
3 \\
3 \\
5 \\
\end{array}$ & $\begin{array}{l}\mathrm{B} \\
\mathrm{B} \\
\mathrm{B} \\
\mathrm{B} \\
\mathrm{B}\end{array}$ & $\begin{array}{l}\text { g/liter } \\
180 \\
180 \\
180 \\
180 \\
180\end{array}$ & $\begin{array}{r}\text { g/liter } \\
0 \\
125 \\
250 \\
375 \\
0\end{array}$ & 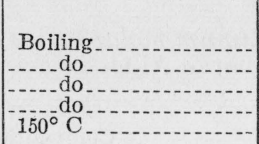 & $\begin{array}{r}\text { g/liter } \\
50.2 \\
42.1 \\
48.6 \\
48.0 \\
48.8\end{array}$ & $\begin{array}{r}\text { g/liter } \\
0.228 \\
.102 \\
.089 \\
.075 \\
.172\end{array}$ & $\begin{array}{l}\% \\
63.2 \\
53.0 \\
61.1 \\
60.3 \\
61.5\end{array}$ & $\begin{array}{r}0.45 \\
.24 \\
.18 \\
.16 \\
.35\end{array}$ \\
\hline 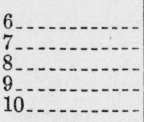 & $\begin{array}{l}\mathrm{B} \\
\mathrm{C} \\
\mathrm{C} \\
\mathrm{C} \\
\mathrm{C}\end{array}$ & $\begin{array}{l}180 \\
157.5 \\
157.5 \\
157.5 \\
157.5\end{array}$ & $\begin{array}{c}250 \\
0 \\
62.5 \\
125 \\
250\end{array}$ & $\begin{array}{l}150^{\circ} \mathrm{C}_{2} \\
\text { Boiling } \\
\text { do }\end{array}$ & $\begin{array}{l}50.1 \\
54.0 \\
53.7 \\
52.5 \\
55.5\end{array}$ & $\begin{array}{l}.056 \\
.324 \\
.177 \\
.147 \\
.130\end{array}$ & $\begin{array}{l}63.1 \\
67.9 \\
67.5 \\
66.0 \\
69.8\end{array}$ & $\begin{array}{l}.12 \\
.60 \\
.33 \\
.28 \\
.24\end{array}$ \\
\hline $\begin{array}{l}11 \\
12 \\
13 \\
14 \\
15\end{array}$ & $\begin{array}{l}\mathrm{C} \\
\mathrm{C} \\
\mathrm{C} \\
\mathrm{D} \\
\mathrm{D}\end{array}$ & $\begin{array}{l}157.5 \\
157.5 \\
157.5 \\
142 \\
142\end{array}$ & $\begin{array}{c}312.5 \\
0 \\
250 \\
0 \\
62.5\end{array}$ & 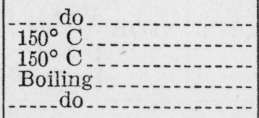 & $\begin{array}{l}53.7 \\
51.6 \\
53.1 \\
61.8 \\
61.3\end{array}$ & $\begin{array}{l}.129 \\
.146 \\
.074 \\
.340 \\
.245\end{array}$ & $\begin{array}{l}67.5 \\
64.9 \\
66.8 \\
77.4 \\
76.8\end{array}$ & $\begin{array}{l}.24 \\
.28 \\
.14 \\
.55 \\
.41\end{array}$ \\
\hline 16 & $\begin{array}{l}\mathrm{D} \\
\mathrm{D} \\
\mathrm{D} \\
\mathrm{D}\end{array}$ & $\begin{array}{l}142 \\
142 \\
142 \\
142\end{array}$ & $\begin{array}{r}125 \\
250 \\
0 \\
250\end{array}$ & $150^{\circ} \mathrm{C}^{\circ} \mathrm{C}^{\circ} \mathrm{C}$ & $\begin{array}{l}61.4 \\
61.8 \\
61.3 \\
60.6\end{array}$ & $\begin{array}{l}.233 \\
.212 \\
.215 \\
.088\end{array}$ & $\begin{array}{l}77.0 \\
77.4 \\
77.0 \\
75.9\end{array}$ & $\begin{array}{l}.38 \\
.34 \\
.35 \\
.14\end{array}$ \\
\hline
\end{tabular}

a Extracted by heating for $3 \mathrm{hr}$.

$\checkmark$ Based on original volume of extracting solution $(400 \mathrm{ml})$.

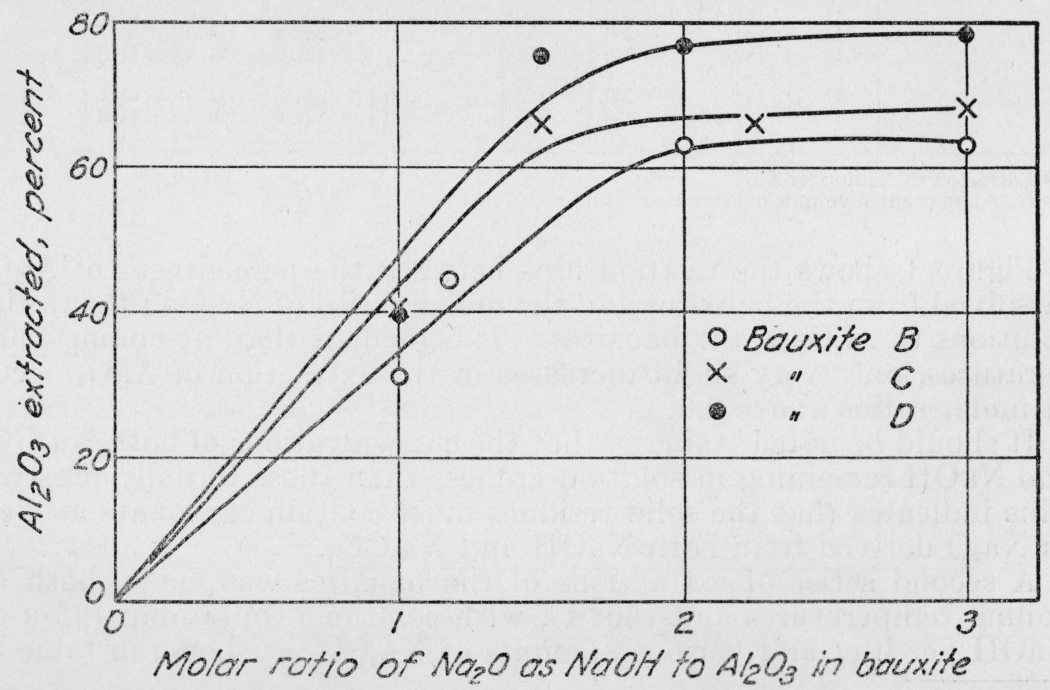

FIGURE 1.-Effect of varying the molar ratio of $\mathrm{Na}_{2} \mathrm{O}$ (as $\mathrm{NaOH}$ ) in the extracting solutions to $\mathrm{Al}_{2} \mathrm{O}_{3}$ in the bauxites. 
Alumina from Clays and High-Silica Bauxites
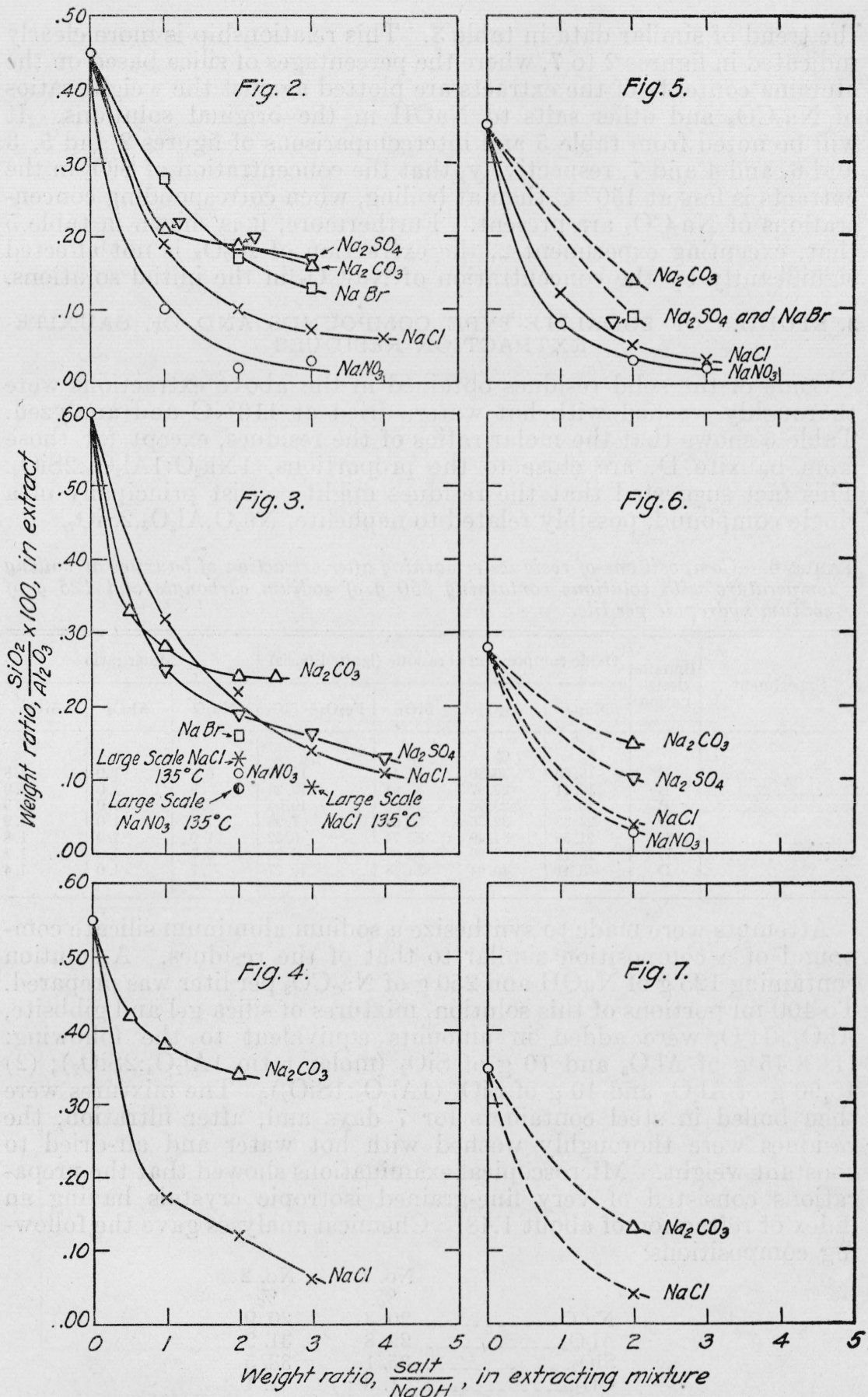

FIGURES 2 to 7.-Effect of sodium salts on the silica-alumina ratio in sodium hydroxide extractions from high-silica bauxites.

Molar ratio of $\mathrm{Na}_{2} \mathrm{O}$ (as $\mathrm{NaOH}$ ) to $\mathrm{Al}_{2} \mathrm{O}_{3}$ in bauxite $=2.0$. Figures 2, 3, and 4, mixtures boiled for $3 \mathrm{hr}$; figures 5,6 , and 7 , mixtures autoclaved at $150^{\circ} \mathrm{C}$ for $3 \mathrm{hr}$; figures 2 and 5 , bauxite B; figures 3 and 6 , figures 5, 6, and 7, mixtures autoclaved at $150^{\circ} \mathrm{C}$ for $3 \mathrm{hr}$; figures 2 and 5 , bauxite B; figures 3 and 6 ,
bauxite C; figures 4 and 7, bauxite D. Points marked "Large Scale" represent |data obtained in small-pilot-plant extractions at $135^{\circ} \mathrm{C}$. 
the trend of similar data in table 3 . This relationship is more clearly indicated in figures 2 to 7 , where the percentages of silica based on the alumina contents of the extracts are plotted against the weight ratios of $\mathrm{Na}_{2} \mathrm{CO}_{3}$ and other salts to $\mathrm{NaOH}$ in the original solutions. It will be noted from table 5 and intercomparisons of figures 2 and 5,3 and 6 , and 4 and 7 , respectively, that the concentration of $\mathrm{SiO}_{2}$ in the extracts is less at $150^{\circ} \mathrm{C}$ than at boiling, when corresponding concentrations of $\mathrm{Na}_{2} \mathrm{CO}_{3}$ are present. Furthermore, it is shown in table 5 that, excepting experiment 2, the extraction of $\mathrm{Al}_{2} \mathrm{O}_{3}$ is not affected significantly by the concentration of $\mathrm{Na}_{2} \mathrm{CO}_{3}$ in the initial solutions.

\section{STUDIES OF SODALITE-TYPE COMPOUNDS AND OF BAUXITE- EXTRACTION RESIDUES}

Some of the solid residues obtained in the above extractions were thoroughly washed with hot water, dried at $110^{\circ} \mathrm{C}$ and analyzed. Table 6 shows that the molar ratios of the residues, except for those from bauxite $\mathrm{D}$, are close to the proportions, $1 \mathrm{Na}_{2} \mathrm{O}: 1 \mathrm{Al}_{2} \mathrm{O}_{3}: 2 \mathrm{SiO}_{2}$. This fact suggested that the residues might consist principally of a single compound, possibly related to nephelite, $\mathrm{Na}_{2} \mathrm{O} \cdot \mathrm{Al}_{2} \mathrm{O}_{3} .2 \mathrm{SiO}_{2}$.

TABLE 6.-Compositions of residues remaining after extraction of bauxites at boiling temperature with solutions containing $250 \mathrm{~g}$ of sodium carbonate and $125 \mathrm{~g}$ of sodium hydroxide per liter

\begin{tabular}{|c|c|c|c|c|c|c|c|c|}
\hline \multirow{2}{*}{ Experiment } & \multirow{2}{*}{$\begin{array}{c}\text { Bauxite } \\
\text { desig- } \\
\text { nation }\end{array}$} & \multicolumn{4}{|c|}{ Oxide composition of residue (ignited basis) } & \multicolumn{3}{|c|}{ Molar ratio } \\
\hline & & $\mathrm{Na}_{2} \mathrm{O}$ & $\mathrm{Al}_{2} \mathrm{O}_{3}$ & $\mathrm{SiO}_{2}$ & $\mathrm{Fe}_{2} \mathrm{O}_{3}+\mathrm{TiO}_{2}$ & $\mathrm{Na}_{2} \mathrm{O}$ & $\mathrm{Al}_{2} \mathrm{O}_{3}$ & $\mathrm{SiO}_{2}$ \\
\hline - & $\begin{array}{l}\text { B } \\
\text { B } \\
\text { B } \\
\text { C } \\
\text { C } \\
\text { D } \\
\text { D }\end{array}$ & $\begin{array}{l}\% \\
15.60 \\
16.41 \\
16.32 \\
23.62 \\
21.55 \\
18.11 \\
16.41\end{array}$ & $\begin{array}{l}\% \\
30.80 \\
29.97 \\
29.96 \\
32.36 \\
34.40 \\
42.26 \\
40.04\end{array}$ & \begin{tabular}{l|}
$\%$ \\
33.47 \\
33.94 \\
34.00 \\
36.04 \\
35.74 \\
30.88 \\
33.18
\end{tabular} & $\begin{array}{r}\% \\
19.55 \\
19.26 \\
19.04 \\
7.98 \\
6.52 \\
8.60 \\
10.27\end{array}$ & $\begin{array}{l}0.8 \\
.9 \\
.9 \\
1.15 \\
1.0 \\
0.7 \\
.7\end{array}$ & $\begin{array}{l}1.0 \\
1.0 \\
1.0 \\
1.0 \\
1.0 \\
1.0 \\
1.0\end{array}$ & $\begin{array}{l}1.8 \\
1.9 \\
1.9 \\
1.9 \\
1.8 \\
1.2 \\
1.4\end{array}$ \\
\hline
\end{tabular}

Attempts were made to synthesize a sodium aluminum silicate compound of a composition similar to that of the residues. A solution containing $125 \mathrm{~g}$ of $\mathrm{NaOH}$ and $250 \mathrm{~g}$ of $\mathrm{Na}_{2} \mathrm{CO}_{3}$ per liter was prepared. To 400-ml portions of this solution, mixtures of silica gel and gibbsite, $\mathrm{Al}_{2} \mathrm{O}_{3} \cdot 3 \mathrm{H}_{2} \mathrm{O}$, were added in amounts equivalent to the following: (1) $8.45 \mathrm{~g}$ of $\mathrm{Al}_{2} \mathrm{O}_{3}$ and $10 \mathrm{~g}$ of $\mathrm{SiO}_{2}$ (molar ratio $1 \mathrm{Al}_{2} \mathrm{O}_{3}: 2 \mathrm{SiO}_{2}$ ); (2) $16.90 \mathrm{~g}$ of $\mathrm{Al}_{2} \mathrm{O}_{3}$ and $10 \mathrm{~g}$ of $\mathrm{SiO}_{2}\left(1 \mathrm{Al}_{2} \mathrm{O}_{3}: 1 \mathrm{SiO}_{2}\right)$. The mixtures were then boiled in steel containers for 7 days and, after filtration, the residues were thoroughly washed with hot water and air-dried to constant weight. Microscopical examinations showed that the preparations consisted of very fine-grained isotropic crystals having an index of refraction of about 1.48. Chemical analyses gave the following compositions:

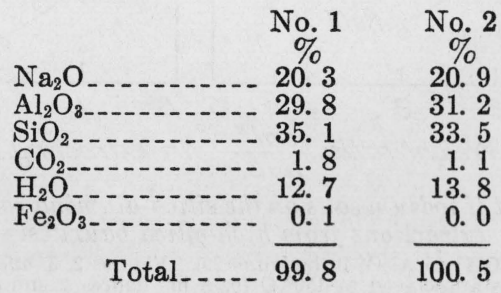


The corresponding $\mathrm{Na}_{2} \mathrm{O}: \mathrm{Al}_{2} \mathrm{O}_{3}: \mathrm{SiO}_{2}: \mathrm{Na}_{2} \mathrm{CO}_{3}: \mathrm{H}_{2} \mathrm{O}$ molar ratios are 0.98:1.00:2.00:0.14:2.42 and 1.02:1.00:1.82:0.09:2.50 for preparations 1 and 2 , respectively.

An X-ray diffraction pattern of sample 1 showed that the structure of the crystals was very similar to that of the mineral sodalite, $3 \mathrm{Na}_{2} \mathrm{O} .3 \mathrm{Al}_{2} \mathrm{O}_{3} \cdot 6 \mathrm{SiO}_{2} \cdot 2 \mathrm{NaCl}$. A sodium aluminum silicate preparation of similar composition (but containing neither carbonate nor chloride) was synthesized. In this experiment a mixture of $26 \mathrm{~g}$ of gibbsite and $20 \mathrm{~g}$ of $\mathrm{SiO}_{2}$, as silica gel (in the molar ratio $1 \mathrm{Al}_{2} \mathrm{O}_{3}: 2 \mathrm{SiO}_{2}$ ) and $600 \mathrm{ml}$ of solution containing $90 \mathrm{~g}$ of $\mathrm{NaOH}$ was heated in an autoclave at $150^{\circ} \mathrm{C}$ for 5 days. The resulting product was filtered and washed with a small amount of hot water, followed by alcohol and then by ether. It was dried overnight at $110^{\circ} \mathrm{C}$. Analysis gave the following composition:

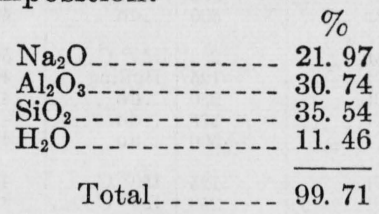

The corresponding molar ratios are $1.17 \mathrm{Na}_{2} \mathrm{O}: 1.00 \mathrm{Al}_{2} \mathrm{O}_{3}: 1.96 \mathrm{SiO}_{2}$ : $2.11 \mathrm{H}_{2} \mathrm{O}$. These ratios are in agreement with the composition of the hydrated nephelite, which has been reported formed in the desilication of sodium aluminate solutions [5]. The material gave an X-ray diffraction pattern distinctly different from that of the preparations containing sodium carbonate. Its pattern was identical, however, with that of the residue from extraction of bauxite $\mathrm{C}$ with sodium hydroxide solution containing no added carbonate (experiment 25, table 7).

In continuation of these studies, an analysis was made of the residue from a laboratory-scale extraction of bauxite $\mathrm{C}$ with a sodium hydroxide-sodium chloride solution (experiment 33, table 7). This residue had the following composition:

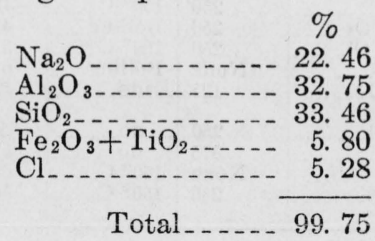

The corresponding molar ratios are $0.90 \mathrm{Na}_{2} \mathrm{O}: 1.00 \mathrm{Al}_{2} \mathrm{O}_{3}: 1.74 \mathrm{SiO}_{2}$ : $0.46 \mathrm{NaCl}$. The X-ray diffraction pattern of this material was identical with that given by a sample of natural sodalite obtained from Canada.

Four minerals have been recognized as belonging to the sodalite group [6], as follows:

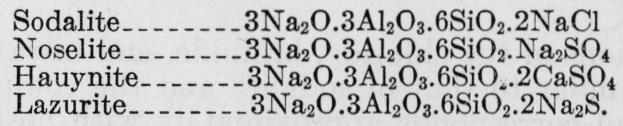

In a further investigation of sodalite-type compounds, mixtures of $26 \mathrm{~g}$ of gibbsite and $20 \mathrm{~g}$ of $\mathrm{SiO}_{2}$ as silica gel (in the molar ratio $1 \mathrm{Al}_{2} \mathrm{O}_{3}: 2 \mathrm{SiO}_{2}$ ) were added to $600-\mathrm{ml}$ quantities of solution containing 
TABLE 7.-Extractions of bauxites with solutions containing $125 \mathrm{~g}$ of sodium hydroxide per liter and various amounts of sodium salts *

\begin{tabular}{|c|c|c|c|c|c|c|c|c|c|}
\hline \multirow{2}{*}{$\begin{array}{c}\text { Experi- } \\
\text { ment }\end{array}$} & \multicolumn{2}{|c|}{ Bauxite } & \multicolumn{2}{|c|}{ Salt added } & \multirow{2}{*}{$\begin{array}{c}\text { Tempera- } \\
\text { ture }\end{array}$} & \multirow{2}{*}{$\begin{array}{l}\mathrm{Al}_{2} \mathrm{O}_{3} \\
\text { in solu- } \\
\text { tion }\end{array}$} & \multirow{2}{*}{$\begin{array}{c}\mathrm{SiO}_{2} \\
\text { in solu- } \\
\text { tion }\end{array}$} & \multirow{2}{*}{$\begin{array}{c}\text { Extrac- } \\
\text { tion of } \\
\mathrm{Al}_{2} \mathrm{O}_{3} \mathrm{~b}\end{array}$} & \multirow{2}{*}{$\frac{\mathrm{SiO}_{2}}{\mathrm{Al}_{2} \mathrm{O}_{3}} \times 100$} \\
\hline & $\begin{array}{c}\text { Designa- } \\
\text { tion }\end{array}$ & $\underset{\text { used }}{\text { Amount }}$ & Kind & Amount & & & & & \\
\hline & $\begin{array}{l}\text { B } \\
\text { B } \\
\text { B } \\
\text { B } \\
\text { B }\end{array}$ & $\begin{array}{c}\text { g/liter } \\
180 \\
180 \\
180 \\
180 \\
180\end{array}$ & $\begin{array}{l}\mathrm{Na}_{2} \mathrm{SO}_{4} \\
\mathrm{Na}_{2} \mathrm{SO}_{4-} \\
\mathrm{Na}_{2} \mathrm{SO}_{4}\end{array}$ & $\begin{array}{r}\text { g/liter } \\
\text { None } \\
125 \\
250 \\
375 \\
\text { None }\end{array}$ & \begin{tabular}{c} 
Boiling \\
\hdashline do \\
\hdashline do \\
$150^{\circ} \mathrm{C}$
\end{tabular} & \begin{tabular}{|r} 
glliter \\
50.2 \\
50.2 \\
50.0 \\
48.2 \\
48.8
\end{tabular} & $\begin{array}{c}\text { g/liter } \\
0.228 \\
.105 \\
.090 \\
.080 \\
.172\end{array}$ & $\begin{array}{l}\% \\
63.2 \\
63.2 \\
63.0 \\
60.6 \\
61.5\end{array}$ & $\begin{array}{l}0.45 \\
.21 \\
.18 \\
.17 \\
.35\end{array}$ \\
\hline 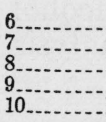 & $\begin{array}{l}\mathrm{B} \\
\mathrm{B} \\
\mathrm{B} \\
\mathrm{B} \\
\mathrm{B}\end{array}$ & $\begin{array}{l}180 \\
180 \\
180 \\
180 \\
180\end{array}$ & $\begin{array}{l}\mathrm{Na}_{2} \mathrm{SO}_{4} \\
\mathrm{NaBr} \\
\mathrm{NaBr} \\
\mathrm{NaBr} \\
\mathrm{NaBr}\end{array}$ & $\begin{array}{l}250 \\
125 \\
250 \\
375 \\
500\end{array}$ & \begin{tabular}{l}
$150^{\circ} \mathrm{C}_{-}$ \\
Boiling \\
\hdashline do \\
do \\
do \\
\end{tabular} & $\begin{array}{l}50.2 \\
49.4 \\
45.6 \\
48.3 \\
49.8\end{array}$ & $\begin{array}{l}.046 \\
.140 \\
.078 \\
.061 \\
.025\end{array}$ & $\begin{array}{l}63.2 \\
62.2 \\
57.4 \\
60.8 \\
62.7\end{array}$ & $\begin{array}{l}.09 \\
.28 \\
.17 \\
.13 \\
.05\end{array}$ \\
\hline $\begin{array}{l}11 . . \\
12 . . \\
13 . . \\
14 . \\
15 . .\end{array}$ & $\begin{array}{l}\text { B } \\
\text { B } \\
\text { B } \\
\text { B } \\
\text { B }\end{array}$ & $\begin{array}{l}180 \\
180 \\
180 \\
180 \\
180\end{array}$ & $\begin{array}{l}\mathrm{NaBr}-. \\
\mathrm{NaCCl}- \\
\mathrm{NaCl}- \\
\mathrm{NaCl}- \\
\mathrm{NaCl} \\
\end{array}$ & $\begin{array}{l}250 \\
125 \\
250 \\
375 \\
500\end{array}$ & \begin{tabular}{c}
$150^{\circ} \mathrm{C}$ \\
Boiling \\
\hdashline$-d o$ \\
\hdashline do \\
\hdashline \\
\hdashline do
\end{tabular} & $\begin{array}{l}50.2 \\
46.4 \\
47.2 \\
47.5 \\
46.3\end{array}$ & $\begin{array}{l}.046 \\
.085 \\
.048 \\
.031 \\
.028\end{array}$ & $\begin{array}{l}63.2 \\
58.4 \\
59.3 \\
59.7 \\
58.2\end{array}$ & $\begin{array}{l}.09 \\
.19 \\
.10 \\
.07 \\
.06\end{array}$ \\
\hline $\begin{array}{l}16 \ldots \\
17 \ldots \\
18 \ldots \\
19 \ldots \\
20 \ldots\end{array}$ & $\begin{array}{l}\mathrm{B} \\
\mathrm{B} \\
\mathrm{B} \\
\mathrm{B} \\
\mathrm{B}\end{array}$ & $\begin{array}{l}180 \\
180 \\
130 \\
180 \\
180\end{array}$ & $\begin{array}{l}\mathrm{NaCl}- \\
\mathrm{NaCl}- \\
\mathrm{NaCl}- \\
\mathrm{NaNO}_{3-} \\
\mathrm{NaNO}_{3}\end{array}$ & $\begin{array}{l}125 \\
250 \\
375 \\
125 \\
250\end{array}$ & $\begin{array}{l}150^{\circ} \mathrm{C} \\
150^{\circ} \mathrm{C} \\
150^{\circ} \mathrm{C} \\
\text { Boiling } \\
\text {-..do }\end{array}$ & $\begin{array}{l}43.9 \\
37.5 \\
50.1 \\
49.1 \\
48.7\end{array}$ & $\begin{array}{l}.054 \\
.017 \\
.016 \\
.048 \\
.010\end{array}$ & $\begin{array}{l}55.3 \\
43.5 \\
63.1 \\
62.0 \\
61.5\end{array}$ & $\begin{array}{l}.12 \\
.05 \\
.03 \\
.10 \\
.02\end{array}$ \\
\hline $\begin{array}{l}21 \ldots . \\
22-. . \\
23 \ldots \\
24-. \\
25 \ldots \\
\end{array}$ & $\begin{array}{l}\mathrm{B} \\
\mathrm{B} \\
\mathrm{B} \\
\mathrm{B} \\
\mathrm{C}\end{array}$ & $\begin{array}{l}180 \\
180 \\
180 \\
180 \\
157.5\end{array}$ & $\begin{array}{l}\mathrm{NaNO}_{3-} \\
\mathrm{NaNO}_{3-} \\
\mathrm{NaNO}_{3-} \\
\mathrm{NaNO}_{3-}\end{array}$ & $\begin{array}{r}375 \\
125 \\
250 \\
375 \\
\text { None }\end{array}$ & $\begin{array}{l}150^{\circ} \mathrm{C}- \\
150^{\circ} \mathrm{C}- \\
150^{\circ} \mathrm{C} \\
\text { Boiling }\end{array}$ & $\begin{array}{l}48.4 \\
46.2 \\
49.4 \\
42.6 \\
54.0\end{array}$ & $\begin{array}{l}.013 \\
.036 \\
.009 \\
.008 \\
.324\end{array}$ & $\begin{array}{l}61.1 \\
58.2 \\
62.2 \\
53.7 \\
67.9\end{array}$ & $\begin{array}{l}.03 \\
.08 \\
.02 \\
.02 \\
.60\end{array}$ \\
\hline 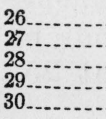 & $\begin{array}{l}\mathrm{C} \\
\mathrm{C} \\
\mathrm{C} \\
\mathrm{C} \\
\mathrm{C}\end{array}$ & $\begin{array}{l}157.5 \\
157.5 \\
157.5 \\
157.5 \\
157.5\end{array}$ & $\begin{array}{l}\mathrm{Na}_{2} \mathrm{SO}_{4-} \\
\mathrm{Na}_{2} \mathrm{SO}_{4-} \\
\mathrm{Na}_{2} \mathrm{SO}_{4-} \\
\mathrm{Na}_{2} \mathrm{SO}_{4} \\
\mathrm{Na}_{2} \mathrm{SO}_{4}\end{array}$ & $\begin{array}{l}125 \\
250 \\
375 \\
500 \\
250\end{array}$ & \begin{tabular}{c} 
do do \\
\hdashline do \\
\hdashline do \\
\hdashline $150^{\circ} \mathrm{C}$
\end{tabular} & $\begin{array}{l}54.0 \\
52.7 \\
49.4 \\
53.8 \\
53.0\end{array}$ & $\begin{array}{l}.135 \\
.102 \\
.080 \\
.071 \\
.053\end{array}$ & $\begin{array}{l}67.8 \\
66.2 \\
62.0 \\
67.8 \\
66.7\end{array}$ & $\begin{array}{l}.25 \\
.19 \\
.16 \\
.13 \\
.10\end{array}$ \\
\hline $\begin{array}{l}31 \ldots \\
32 \ldots \\
33 \ldots \\
34 \ldots \\
35 \ldots\end{array}$ & $\begin{array}{l}\mathrm{C} \\
\mathrm{C} \\
\mathrm{C} \\
\mathrm{C} \\
\mathrm{C}\end{array}$ & $\begin{array}{l}157.5 \\
157.5 \\
157.5 \\
157.5 \\
157.5\end{array}$ & $\begin{array}{l}\mathrm{NaBr}-. \\
\mathrm{NaCl}- \\
\mathrm{NaCl}- \\
\mathrm{NaCl}- \\
\mathrm{NaCl}-\end{array}$ & $\begin{array}{l}250 \\
125 \\
250 \\
375 \\
500\end{array}$ & \begin{tabular}{|c} 
Boiling \\
- do \\
do \\
- do \\
- do
\end{tabular} & $\begin{array}{l}47.7 \\
51.3 \\
51.2 \\
50.4 \\
50.5\end{array}$ & $\begin{array}{l}.076 \\
.169 \\
.113 \\
.071 \\
.056\end{array}$ & $\begin{array}{l}60.0 \\
64.5 \\
64.4 \\
63.4 \\
63.4\end{array}$ & $\begin{array}{l}.16 \\
.33 \\
.22 \\
.14 \\
.11\end{array}$ \\
\hline $\begin{array}{l}36 \ldots \\
37 \ldots \\
38 \\
39 \\
49 \\
40 . . \\
\end{array}$ & $\begin{array}{l}\text { C } \\
C \\
C \\
D \\
D\end{array}$ & $\begin{array}{l}157.5 \\
157.5 \\
157.5 \\
142 \\
142\end{array}$ & $\begin{array}{l}\mathrm{NaCl} \\
\mathrm{NaNO}_{3} \\
\mathrm{NaNO}^{3} \\
\mathrm{NaCl}_{-}\end{array}$ & $\begin{array}{r}250 \\
250 \\
250 \\
\text { None } \\
125\end{array}$ & $\begin{array}{l}150^{\circ} \mathrm{C} \\
\text { Boiling } \\
150^{\circ} \mathrm{C} \\
\text { Boiling } \\
\\
\text { do }\end{array}$ & $\begin{array}{l}48.2 \\
47.1 \\
51.8 \\
61.8 \\
59.2\end{array}$ & $\begin{array}{l}.021 \\
.057 \\
.018 \\
.340 \\
.102\end{array}$ & $\begin{array}{l}60.6 \\
59.3 \\
65.2 \\
77.4 \\
74.4\end{array}$ & $\begin{array}{l}.04 \\
.12 \\
.03 \\
.55 \\
.17\end{array}$ \\
\hline $\begin{array}{l}41 \ldots . . \\
42 \ldots . . \\
43 \ldots \\
44 \ldots\end{array}$ & $\begin{array}{l}D \\
D \\
D \\
D\end{array}$ & $\begin{array}{l}142 \\
142 \\
142 \\
142\end{array}$ & $\begin{array}{l}\mathrm{NaCl} \\
\mathrm{NaCl} \\
\mathrm{NaCl}_{-}\end{array}$ & $\begin{array}{r}250 \\
375 \\
\text { None } \\
250\end{array}$ & $\begin{array}{l}\text { do } \\
150^{\circ} \mathrm{C}_{-} \\
150^{\circ} \mathrm{C}\end{array}$ & $\begin{array}{l}56.8 \\
52.6 \\
61.3 \\
56.0\end{array}$ & $\begin{array}{l}.069 \\
.032 \\
.215 \\
.024\end{array}$ & $\begin{array}{l}71.5 \\
66.2 \\
77.0 \\
70.2\end{array}$ & $\begin{array}{l}.12 \\
.06 \\
.35 \\
.04\end{array}$ \\
\hline
\end{tabular}

* Extracted by heating for $3 \mathrm{hr}$.

b Based on original volume of extracting solution (400 ml).

$75 \mathrm{~g}$ of $\mathrm{NaOH}$ and $150 \mathrm{~g}$ of $\mathrm{NaCl}, \mathrm{NaBr}, \mathrm{NaNO}_{3}$, or $\mathrm{Na}_{2} \mathrm{SO}_{4}$. The mixtures were kept in the autoclave at $150^{\circ} \mathrm{C}$ for 5 days and were shaken twice daily. The resulting products were then filtered, washed thoroughly with hot water, alcohol, and ether, and dried at $110^{\circ} \mathrm{C}$ overnight. Analysis of the preparations gave the results shown in table 8 .

The compositions of the chloride, bromide, and nitrate double salts in table 8 are similar to that of sodalite and the composition of the sulfate compound corresponds approximately with noselite. All the synthetic preparations contain less sodium salt than corresponds to the theoretical compositions and are hydrated, whereas the pure compounds should be anhydrous. 
TABLE 8.-Composition of sodalite-type compounds a

\begin{tabular}{|c|c|c|c|c|c|c|c|c|c|c|c|}
\hline \multirow{2}{*}{$\begin{array}{c}\text { Experi- } \\
\text { ment }\end{array}$} & \multirow{2}{*}{$\begin{array}{l}\text { Sodium salt } \\
(\text { NaX b ) in } \\
\text { molecule }\end{array}$} & \multicolumn{5}{|c|}{ Oxide composition } & \multicolumn{5}{|c|}{ Molar ratios } \\
\hline & & $\mathrm{Na}_{2} \mathrm{O}$ & $\mathrm{Al}_{2} \mathrm{O}_{3}$ & $\mathrm{SiO}_{2}$ & $\mathrm{X}^{0}$ & $\mathrm{H}_{2} \mathrm{O}$ & $\mathrm{Na}_{2} \mathrm{O}$ & $\mathrm{Al}_{2} \mathrm{O}_{3}$ & $\mathrm{SiO}_{2}$ & $\mathrm{NaX} b$ & $\mathrm{H}_{2} \mathrm{O}$ \\
\hline $\begin{array}{l}4 \\
5\end{array}$ & $\begin{array}{l}\text { None } \\
\mathrm{NaCl} \\
\mathrm{NaBr} \\
\mathrm{NaNO} \\
\mathrm{Na}_{2} \mathrm{SO}_{4}\end{array}$ & $\begin{array}{c}\% \\
21.97 \\
22.71 \\
22.39 \\
21.22 \\
22.14\end{array}$ & $\begin{array}{c}\% \\
30.74 \\
30.28 \\
29.80 \\
32.06 \\
29.86\end{array}$ & $\begin{array}{c}\% \\
35.54 \\
35.20 \\
33.46 \\
34.64 \\
34.18\end{array}$ & \begin{tabular}{r}
\multicolumn{1}{c}{$\%$} \\
5.53 \\
11.45 \\
8.24 \\
6.53
\end{tabular} & $\begin{array}{r}\% \\
11.46 \\
5.76 \\
3.43 \\
3.64 \\
7.12\end{array}$ & $\begin{array}{l}1.17 \\
0.96 \\
.99 \\
.85 \\
.94\end{array}$ & $\begin{array}{l}1.00 \\
1.00 \\
1.00 \\
1.00 \\
1.00\end{array}$ & $\begin{array}{l}1.96 \\
1.97 \\
1.91 \\
1.83 \\
1.94\end{array}$ & $\begin{array}{l}0.53 \\
.49 \\
.49 \\
.28\end{array}$ & $\begin{array}{l}2.1 \\
1.1 \\
0.7 \\
.6 \\
1.3\end{array}$ \\
\hline
\end{tabular}

a Prepared from mixtures (heated at $150^{\circ} \mathrm{C}$ for 5 days) of $26 \mathrm{~g}$ of gibbsite and $20 \mathrm{~g}$ of $\mathrm{SiO}_{2}$ as silica gel $\left(1 \mathrm{Al}_{2} \mathrm{O}_{3}: 2 \mathrm{SiO}_{2}\right.$, molar) in $600 \mathrm{ml}$ of solution containing $75 \mathrm{~g}$ of $\mathrm{NaOH}$ and $150 \mathrm{~g}$ of $\mathrm{NaCl}, \mathrm{NaBr}$, $\mathrm{NaNO}_{3}$, or $\mathrm{Na}_{2} \mathrm{SO}_{4}$.

b $\mathrm{NaX}=\mathrm{NaCl}, \mathrm{NaBr}, \mathrm{NaNO}_{3}$, or $\mathrm{Na}_{2} \mathrm{SO}_{4}$.

- $\mathrm{X}=\mathrm{Cl}, \mathrm{Br}, \mathrm{N}_{2} \mathrm{O}_{5}$, or $\mathrm{SO}_{3}$.

Table 9 shows the results of comparisons of the X-ray diffraction patterns of the various synthetic preparations and of the extraction residues from bauxite $\mathrm{C}$ with the pattern of natural sodalite. The patterns of the separate compounds within groups $1,2,3,4$, and 5 were identical with each member of the group, but each group pattern differed in various degrees from the pattern of sodalite. In the case of the $\mathrm{NaBr}$ preparations, the patterns were different from that of sodalite only in indicating a slightly larger unit-cube size, whereas for the $\mathrm{NaNO}_{3}$ preparations, slight variations from the sodalite pattern were noted. The sulfate preparation had a pattern different from that of sodalite and also from that of naturally occurring noselite. Unexpectedly, the pattern of the residue of bauxite C, extracted with $\mathrm{NaOH}-\mathrm{Na}_{2} \mathrm{SO}_{4}$ solution, fell in group 5 with sodium aluminum silicate hydrate and showed no similarity to the pattern of the synthetic sulfate compound.

TABLE 9.-Comparison of X-ray diffraction patterns of sodalite-type compounds

\begin{tabular}{|c|c|c|c|}
\hline Experiment & $\begin{array}{l}\text { Sodium salt } \\
\text { in molecule }\end{array}$ & Source of preparation & $\begin{array}{l}\text { Degree of similarity } \\
\text { with X-ray pattern of } \\
\text { sodalite as given in } \\
\text { literature }\end{array}$ \\
\hline $\begin{array}{l}1 \mathrm{a} \\
1 \mathrm{~b} \\
1 \mathrm{c} \\
2 \mathrm{a} \\
2 \mathrm{~b} \\
\mathrm{~b}\end{array}$ & \begin{tabular}{|l}
$\mathrm{NaCl}$ \\
\hdashline $\mathrm{do}$ \\
\hdashline $\mathrm{do}$ \\
$\mathrm{NaB}$
\end{tabular} & $\begin{array}{l}\text { Natural sodalite, Canada } \\
\text { Synthetic } \\
\text { NaOH-NaCl extraction residue of bauxite } \mathrm{C} \\
\text { Synthetic } \\
\mathrm{NaOH}-\mathrm{NaBr} \text { extraction residue of bauxite } \mathrm{C}\end{array}$ & $\begin{array}{l}\text { Identical. } \\
\text { Do. } \\
\text { Do. } \\
\text { Almost identical. } \\
\text { Do. }\end{array}$ \\
\hline $\begin{array}{l}3 \mathrm{a} \\
3 \mathrm{~b} \\
4 \\
5 \mathrm{a} \\
5 \mathrm{~b}\end{array}$ & \begin{tabular}{l}
$\mathrm{NaNO}_{3}$ \\
\hdashline $\mathrm{Na}_{2} \mathrm{SO}_{4}$ \\
$\mathrm{None}$ \\
-
\end{tabular} & $\begin{array}{l}\text { Synthetic } \\
\text { NaOH-NaNO } \\
\text { Synthetic.. extraction residue of bauxite } \mathrm{C}_{3} \\
\mathrm{NaOH} \text { extraction residue of bauxite } \mathrm{C}\end{array}$ & $\begin{array}{l}\text { Very similar. } \\
\text { Do. } \\
\text { Different. } \\
\text { Do. } \\
\text { Do. }\end{array}$ \\
\hline $5 c$ & $\mathrm{Na}_{2} \mathrm{SO}_{4-}$ & $\mathrm{NaOH}-\mathrm{Na}_{2} \mathrm{SO}_{4}$ extraction residue of bauxite $\mathrm{C} . .$. & Do. \\
\hline
\end{tabular}

\section{COMPARISON OF EFFECTIVENESS OF VARIOUS SALTS IN DE- PRESSING THE CONCENTRATION OF SILICA IN SODIUM ALUMINATE SOLUTIONS}

These experiments suggested that the decreased concentrations of silica obtained in sodium aluminate solutions in the presence of sodium carbonate might be caused by the formation of a compound similar to sodalite and having a lower solubility than that of the sodium aluminum silicate formed in the absence of sodium carbonate. They 
suggested also that under the conditions of extraction other sodium salts, particularly sodium chloride, might form sodalitic-type compounds, possibly having lower solubilities than the carbonate compound. Accordingly, the investigation was extended to determine which sodium salt would be more effective in depressing the solubility of silica in sodium aluminate solutions.

A considerable number of extractions of bauxites B, C, and D were made with a solution containing $125 \mathrm{~g}$ of $\mathrm{NaOH}$ per liter and various added salts in the amounts shown in table 7 . Exactly the same procedure was followed in these experiments as in those reported in table 5 .

Figures 2 to 7 , based on data in tables 5 and 7 , indicate the purity of the $\mathrm{Al}_{2} \mathrm{O}_{3}$ in solution with respect to $\mathrm{SiO}_{2}$ in the presence of the various salts. It is evident that sodium nitrate is the most effective, of the salts tried, in reducing the concentration of $\mathrm{SiO}_{2}$ in the sodium aluminate extracts. Next in order are the halide salts, and of these the chloride is shown to be more effective than the bromide where comparable data are available. The behavior of sodium sulfate and sodium carbonate is somewhat erratic, but in most cases the former causes the larger reductions in the concentration of $\mathrm{SiO}_{2}$. Generally, the amounts of $\mathrm{SiO}_{2}$ found in the $150^{\circ} \mathrm{C}$ extracts are considerably lower than those obtained at boiling at atmospheric pressure, but with bauxite $\mathrm{B}$ in the presence of $\mathrm{NaNO}_{3}$, boiling appears to be almost as effective as treatment at $150^{\circ} \mathrm{C}$.

The economic advantages and effectiveness of sodium chloride are such that it seemed desirable, in the remainder of this investigation, to concentrate on the use of common salt as a desilication agent.

\section{PILOT-PLANT EXTRACTIONS}

A number of extractions of bauxites $\mathrm{B}, \mathrm{C}$, and $\mathrm{D}$ were made in a small pilot plant. This equipment consisted of 30 -gallon iron digester fitted with a mechanical stirrer and having steam, water, and air inlets. The digester was connected with a filter press from which the filtrate flowed to two 50-gallon storage drums. A centrifugal pump in the circuit permitted transfer of the solution from one storage drum to another or back to the digester.

The quantities of materials used and data obtained in some representative extractions are given in table 10 . The solution containing sodium hydroxide and dissolved sodium salt was heated to boiling by passing steam into the digester. The bauxite then was added, and the mixture was heated at the desired temperature for 3 hours while stirring constantly. In experiments 1,2 , and 3 of table 10 the extractions were made at atmospheric pressure and, in experiments 4, 5 , and 6 , at approximately $30-\mathrm{lb} /$ in. $^{2}$ gage pressure $\left(135^{\circ} \mathrm{C}\right)$. At the completion of the heating period each mixture was filtered, the filter cake thoroughly washed with hot water, and the volume of the extract plus wash water determined. Analyses of the solutions were made for $\mathrm{Na}_{2} \mathrm{CO}_{3}, \mathrm{NaOH}, \mathrm{Al}_{2} \mathrm{O}_{3}$, and $\mathrm{SiO}_{2}$.

It will be noted that the recoveries of $\mathrm{Al}_{2} \mathrm{O}_{3}$ reported in table 10 are slightly lower than those obtained in laboratory-scale extractions. This was caused by an accumulation of minor losses that could not be avoided in the pilot plant setup. The percentages of silica in experiments 4,5 , and 6 , based on the $\mathrm{Al}_{2} \mathrm{O}_{3}$ content of the solutions, 
TABLE 10.-Pilot-plant extractions of bauxites a

\begin{tabular}{|c|c|c|c|c|c|c|c|c|c|c|c|c|c|c|c|c|}
\hline \multirow{2}{*}{$\begin{array}{c}\text { Experi- } \\
\text { ment }\end{array}$} & \multicolumn{2}{|c|}{ Bauxite } & \multicolumn{2}{|l|}{ Salt added } & \multirow{2}{*}{$\begin{array}{l}\mathrm{NaOH} \\
\text { added }\end{array}$} & \multicolumn{2}{|c|}{ Volume of- } & \multicolumn{4}{|c|}{ Composition of extract plus wash } & \multicolumn{3}{|c|}{ Recoveries of- } & \multirow{2}{*}{$\frac{\mathrm{SiO}_{2}}{\mathrm{Al}_{2} \mathrm{O}_{3}} \times 100$} & \multirow{2}{*}{$\begin{array}{l}\frac{\mathrm{SiO}_{2}}{\mathrm{Al}_{2} \mathrm{O}_{3}} \times 100 \\
\text { in precip- } \\
\text { itated } \\
\mathrm{Al}_{2} \mathrm{O}_{3} .3 \mathrm{H}_{2} \mathrm{O}\end{array}$} \\
\hline & $\begin{array}{l}\text { Desig- } \\
\text { nation }\end{array}$ & $\begin{array}{l}\text { Quan- } \\
\text { tity } \\
\text { used }\end{array}$ & Kind & Amount & & $\begin{array}{l}\text { Initial } \\
\text { solu- } \\
\text { tion }\end{array}$ & $\begin{array}{c}\text { Extract } \\
\text { plus } \\
\text { wash }\end{array}$ & $\mathrm{Na}_{2} \mathrm{CO}_{3}$ & $\mathrm{NaOH}$ & $\mathrm{Al}_{2} \mathrm{O}_{3}$ & $\mathrm{SiO}_{2}$ & $\mathrm{Na}_{2} \mathrm{CO}_{3}$ & $\mathrm{NaOH}$ & $\mathrm{Al}_{2} \mathrm{O}_{3}$ & & \\
\hline $\begin{array}{l}1 \\
2 \\
3\end{array}$ & $\begin{array}{l}B \\
D \\
D\end{array}$ & \begin{tabular}{l}
\multicolumn{1}{l}{$b$} \\
20.0 \\
17.25 \\
17.25
\end{tabular} & \begin{tabular}{|c|}
$\mathrm{Na}_{2} \mathrm{CO}_{3}$ \\
\hdashline $\mathrm{do}$
\end{tabular} & $\begin{array}{l}l b \\
27.8 \\
30.0 \\
30.0\end{array}$ & $\begin{array}{l}l b \\
13.9 \\
15.0 \\
15.0\end{array}$ & $\begin{array}{l}\text { gal } \\
13.1 \\
13.2 \\
14.0\end{array}$ & $\begin{array}{l}g a l \\
32.9 \\
29.4 \\
36.4\end{array}$ & $\begin{array}{r}\text { g/liter } \\
77.5 \\
105.4 \\
81.3\end{array}$ & $\begin{array}{r}\text { g/liter } \\
39.2 \\
56.0 \\
43.8\end{array}$ & $\begin{array}{r}\text { g/liter } \\
18.6 \\
29.8 \\
22.6\end{array}$ & $\begin{array}{r}\text { g/liter } \\
0.046 \\
.089 \\
.072\end{array}$ & $\begin{array}{l}\% \\
75 \\
86 \\
82\end{array}$ & $\begin{array}{l}\% \\
77 \\
92 \\
89\end{array}$ & $\begin{array}{l}\% \\
58 \\
75 \\
71\end{array}$ & $\begin{array}{r}0.25 \\
.30 \\
.32\end{array}$ & $\begin{array}{r}0.20 \\
.27 \\
.21\end{array}$ \\
\hline $\begin{array}{l}4 \\
5 \\
6\end{array}$ & $\begin{array}{l}\mathrm{C} \\
\mathrm{C} \\
\mathrm{C}\end{array}$ & $\begin{array}{l}15.8 \\
15.8 \\
12.6\end{array}$ & $\begin{array}{l}\mathrm{NaCl} \\
-\mathrm{NaNO}_{3} \\
\mathrm{do}\end{array}$ & $\begin{array}{l}25.0 \\
37.5 \\
20.0\end{array}$ & $\begin{array}{l}12.5 \\
12.5 \\
10.0\end{array}$ & $\begin{array}{r}11.0 \\
10.9 \\
9.0\end{array}$ & $\begin{array}{l}23.5 \\
21.4 \\
30.3\end{array}$ & & (n) & $\begin{array}{l}24.5 \\
26.7 \\
14.2\end{array}$ & $\begin{array}{l}.034 \\
.024 \\
.013\end{array}$ & & 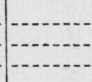 & $\begin{array}{l}60 \\
60 \\
63\end{array}$ & $\begin{array}{l}.14 \\
.09 \\
.09\end{array}$ & $\begin{array}{l}.14 \\
.09 \\
.09\end{array}$ \\
\hline
\end{tabular}

Experiments 1, 2, and 3 were made at the boiling temperatures of the solutions at atmospheric pressure, and experiments 4,5 , and 6 at $135^{\circ} \mathrm{C}(30-1 \mathrm{~b}$ gage pressure). Time of extraction was $3 \mathrm{hr}$. 
are plotted in figure 3. These values are comparable with those obtained in the small-scale extractions.

On completion of each extraction, the combined filtrate and wash contained in the storage drum was heated to boiling. Carbon dioxide was then passed slowly into the solution, which was kept in continuous agitation. Addition of carbon dioxide was continued over a period of 8 to 10 hours, until less than $0.5 \mathrm{~g}$ of $\mathrm{Al}_{2} \mathrm{O}_{3}$ per liter remained in solution. The mixture of precipitate and solution was then pumped into the digester, from which it was filtered on the filter press, and the precipitate was washed four times with 10-gallon portions of hot water. The material was removed from the filter press and dried overnight.

Microscopical examinations of the products showed that they consisted of irregular or prismatic crystals having the refractive indices of gibbsite. Analyses of the material for $\mathrm{SiO}_{2}$ and $\mathrm{Al}_{2} \mathrm{O}_{3}$ gave the ratios shown in the last column of table 10 . These values are she same or somewhat lower than those for the solutions before precipitation of the alumina. The soda contents of gibbsite from experiments 2 and 3 were 0.3 and 0.4 percent, respectively, and the $\mathrm{Fe}_{2} \mathrm{O}_{3}$ content of the latter was 0.09 percent. This relatively high value for $\mathrm{Fe}_{2} \mathrm{O}_{3}$ was undoubtedly caused by mechanical contamination. This was extremely difficult to prevent because the same equipment had to be used both for the extractions and for precipitation and handling of the hydrated alumina.

The precipitation of alumina from silica by differential precipitation was not investigated as this problem has received considerable study in connection with commercial operation of the Bayer process. McCulloch [7] has shown that by means of carbon dioxide, alumina containing 0.02 to 0.03 percent of silica can be precipitated from solutions containing 75 to $80 \mathrm{~g}$ of $\mathrm{Al}_{2} \mathrm{O}_{3}$ and 0.15 to $0.25 \mathrm{~g}$ of $\mathrm{SiO}_{2}$ per liter, provided precipitation is stopped when about 75 percent of the alumina has been removed from solution.

As separation of alumina from silica by differential precipitation is most effective when the alumina concentration is high, extracts similar to those obtained in this study should not be diluted by excessive quantities of wash water prior to separation of the alumina.

\section{RECOVERY OF SODA AND ALUMINA FROM BAUXITE- EXTRACTION RESIDUES}

A number of experiments were performed on the recovery of $\mathrm{Na}_{2} \mathrm{O}$ and $\mathrm{Al}_{2} \mathrm{O}_{3}$ from the bauxite-extraction residues. As shown previously, such residues contain $\mathrm{Na}_{2} \mathrm{O}, \mathrm{Al}_{2} \mathrm{O}_{3}$, and $\mathrm{SiO}_{2}$ in molar ratios approximating $1: 1: 2$ as an insoluble sodium aluminum silicate complex.

In most of the experiments, the residues were mixed with approximately the quantities of $\mathrm{CaCO}_{3}$ required to form dicalcium silicate with the silica, leaving the $\mathrm{Na}_{2} \mathrm{O}$ and $\mathrm{Al}_{2} \mathrm{O}_{3}$ as sodium aluminate. A few mixtures were also prepared in which lime and silica were present in molar ratios of 1 and 3 . In some experiments, data for which are included in table $11, \mathrm{Na}_{2} \mathrm{CO}_{3}$, as well as $\mathrm{CaCO}_{3}$, was added. This was also done in the treatment of a bauxitic clay, experiment 11, table 11. The mixtures in 25 to $30-\mathrm{g}$ quantities were heated in an electric furnace and held for 1 hour at the temperatures indicated in the table. The products were ground to pass a No. 80 sieve. 
TABLE 11.-Extractions of $\mathrm{Al}_{2} \mathrm{O}_{3}$ and $\mathrm{Na}_{2} \mathrm{O}$ from sinters prepared from bauxite-extraction residues

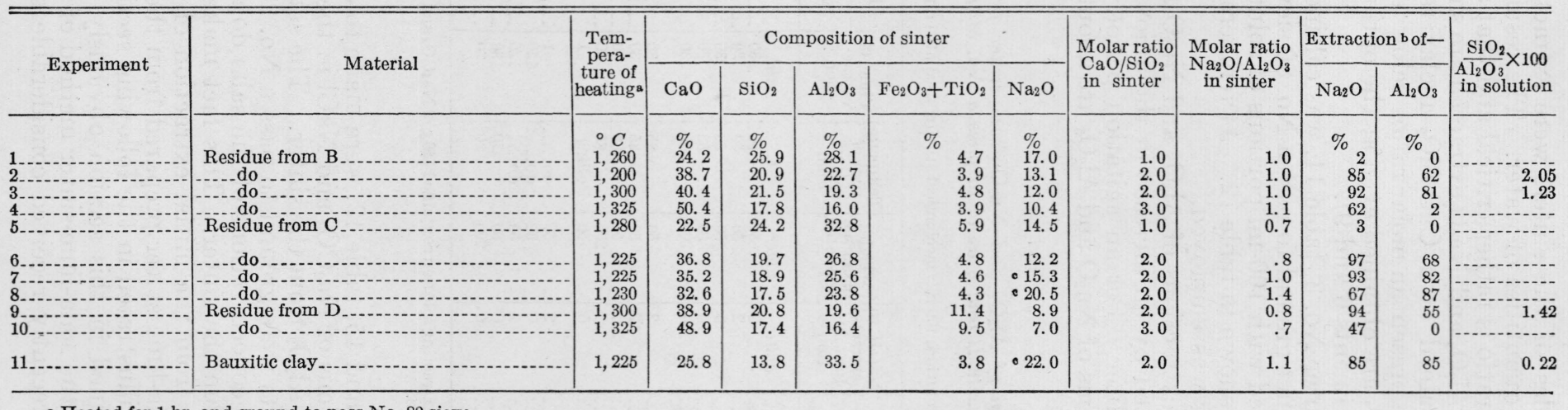

Heated for $1 \mathrm{hr}$. and ground to pass No. 80 sieve.

Two-gram samples of the sinters were extracted by boiling for $2 \mathrm{hrs}$ with 100-ml quantities of water. 
Two-gram samples of the sinters were extracted by boiling for 2 hours with $100-\mathrm{ml}$ quantities of water. The results in table 11 show that the $\mathrm{CaO} / \mathrm{SiO}_{2}$ ratio is rather critical and that at values of 1.0 and 3.0 the amounts of $\mathrm{Al}_{2} \mathrm{O}_{3}$ and $\mathrm{Na}_{2} \mathrm{O}$ extracted are sharply reduced from the quantities obtained at a $\mathrm{CaO} / \mathrm{SiO}_{2}$ molar ratio of 2.0 . When $\mathrm{Na}_{2} \mathrm{O}$ and $\mathrm{Al}_{2} \mathrm{O}_{3}$ are present in molar ratios below unity, unsatisfactory extractions of $\mathrm{Al}_{2} \mathrm{O}_{3}$ are obtained even at the optimum molar ratios of $\mathrm{CaO}$ to $\mathrm{SiO}_{2}$ (experiments 6 and 9 ).

A quantity of sinter No. 3 , table 11 , was calcined at $1,300^{\circ} \mathrm{C}$ for 1 hour, and the product ground to pass a No. 80 sieve. Samples of the sinter were extracted with $100-\mathrm{ml}$ portions of solutions containing the amounts of $\mathrm{NaOH}$ shown in table 12. At temperatures below boiling, mechanical stirring was employed.

The percentage extractions of $\mathrm{Al}_{2} \mathrm{O}_{3}$ and $\mathrm{Na}_{2} \mathrm{O}$ from this sinter are only slightly affected by an increase in the amount of sinter treated from 50 to $200 \mathrm{~g} /$ liter. For an agitation period of 30 minutes, the maximum extractions of $\mathrm{Na}_{2} \mathrm{O}$ and $\mathrm{Al}_{2} \mathrm{O}_{3}$ are about 90 and 85 percent, respectively.

TABLE 12.-Extraction of $\mathrm{Al}_{2} \mathrm{O}_{3}$ and $\mathrm{Na}_{2} \mathrm{O}$ from sinter prepared from residue of bauxite $B$ and ground to pass a No. 80 sieve

[Volume of extracting solution, $100 \mathrm{ml}$; mechanical stirring used at temperatures below boiling.]

\begin{tabular}{|c|c|c|c|c|c|c|c|}
\hline \multirow{2}{*}{ Experiment } & \multirow{2}{*}{$\begin{array}{c}\mathrm{NaOH} \text { in } \\
\text { extract- } \\
\text { ing solu- } \\
\text { tion }\end{array}$} & \multirow{2}{*}{$\begin{array}{l}\text { Weight } \\
\text { of sample } \\
\text { extracted }\end{array}$} & \multirow{2}{*}{$\begin{array}{l}\text { Tempera- } \\
\text { ture of } \\
\text { extrac- } \\
\text { tion }\end{array}$} & \multirow{2}{*}{$\begin{array}{l}\text { Time of } \\
\text { extrac- } \\
\text { tion }\end{array}$} & \multicolumn{2}{|c|}{ Extraction of- } & \multirow{2}{*}{$\begin{array}{l}\frac{\mathrm{SiO}_{2}}{\mathrm{Al}_{2} \mathrm{O}_{3}} \times 100 \\
\text { in solution }\end{array}$} \\
\hline & & & & & $\mathrm{Na}_{2} \mathrm{O}$ & $\mathrm{Al}_{2} \mathrm{O}_{3}$ & \\
\hline $\begin{array}{l}1 \\
4 \\
5\end{array}$ & $\begin{array}{r}\text { glliter } \\
0 \\
2 \\
10 \\
0 \\
0\end{array}$ & $\begin{array}{r}\text { o/liter } \\
50 \\
50 \\
50 \\
50 \\
200\end{array}$ & $\begin{array}{r}{ }^{\circ} C_{50} \\
50 \\
50 \\
50 \\
85 \\
85\end{array}$ & $\begin{array}{r}\min \\
30 \\
30 \\
30 \\
30 \\
30\end{array}$ & \begin{tabular}{r}
$\%$ \\
\hdashline 91 \\
90
\end{tabular} & $\begin{array}{c}\% \\
65 \\
76 \\
83 \\
72 \\
72\end{array}$ & 0.33 \\
\hline $\begin{array}{l}6 \\
7 \\
8 \\
9\end{array}$ & $\begin{array}{r}2 \\
12 \\
100 \\
12 \\
0\end{array}$ & $\begin{array}{r}50 \\
50 \\
50 \\
200 \\
50\end{array}$ & $\begin{array}{r}85 \\
85 \\
85 \\
85 \\
\text { Boiling }\end{array}$ & $\begin{array}{r}30 \\
30 \\
30 \\
30 \\
1\end{array}$ & (n) & $\begin{array}{l}85 \\
85 \\
82 \\
80 \\
69\end{array}$ & $\begin{array}{l}.75 \\
75\end{array}$ \\
\hline 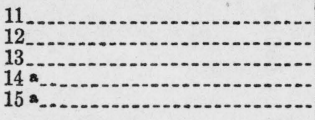 & $\begin{array}{l}2 \\
0 \\
2 \\
0 \\
0\end{array}$ & $\begin{array}{r}50 \\
50 \\
50 \\
50 \\
200\end{array}$ & \begin{tabular}{r}
.- do \\
\hdashline- do $_{-. . .}$ \\
\hdashline- do \\
70 \\
70
\end{tabular} & $\begin{array}{r}1 \\
120 \\
120 \\
30 \\
30\end{array}$ & 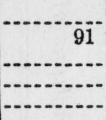 & $\begin{array}{l}66 \\
71 \\
79 \\
84 \\
82\end{array}$ & - \\
\hline
\end{tabular}

- In these experiments the extracting solution contained $150 \mathrm{~g}$ of $\mathrm{Na}_{2} \mathrm{CO}_{3}$ and $200 \mathrm{~g}$ of $\mathrm{NaCl}$ per liter. Sinters ground to pass a No. 200 sieve.

Experiments 14 and 15, table 12, were made to determine the effect of high concentrations of $\mathrm{Na}_{2} \mathrm{CO}_{3}$ and $\mathrm{NaCl}$ in the extracting solution on the recovery of $\mathrm{Al}_{2} \mathrm{O}_{3}$ from the sinter. The samples of sinter used in these experiments were ground to pass a No. 200 sieve. It is evident that the high concentrations of the salts do not diminish the recovery of $\mathrm{Al}_{2} \mathrm{O}_{3}$ from the sinter. This fact makes it possible to use the spent solution from the initial extraction of the bauxite for extraction of the soda-lime sinter prepared from the bauxite-extraction residue, as will be illustrated in the following section.

The data contained in this section obviously do not represent a thorough study of the soda-lime-sinter method of alumina extraction. This process has recently received considerable study elsewhere [8]. 


\section{FLOW SHEET AND SUMMARY OF PROCESS}

A suggested commercial process for the extraction of alumina from high-silica bauxites, developed from experiments described in the preceding sections, is illustrated by a flow sheet, figure 8 .

The composition of the bauxite shown in the flow sheet is approximately that of bauxite $\mathrm{C}$, with minor constituents such as $\mathrm{Fe}_{2} \mathrm{O}_{3}$ and $\mathrm{TiO}_{2}$, omitted for simplification. The finely ground material is digested for a suitable time with a sodium hydroxide-sodium chloride solution, either at the boiling temperature of the solution at atmospheric pressure or at a higher temperature and pressure. On completion of the heating period, the mixture is filtered and the residue washed with water or salt solution. Washing need not be thorough because the residue is reserved for further treatment to recover the soda and alumina that it contains.

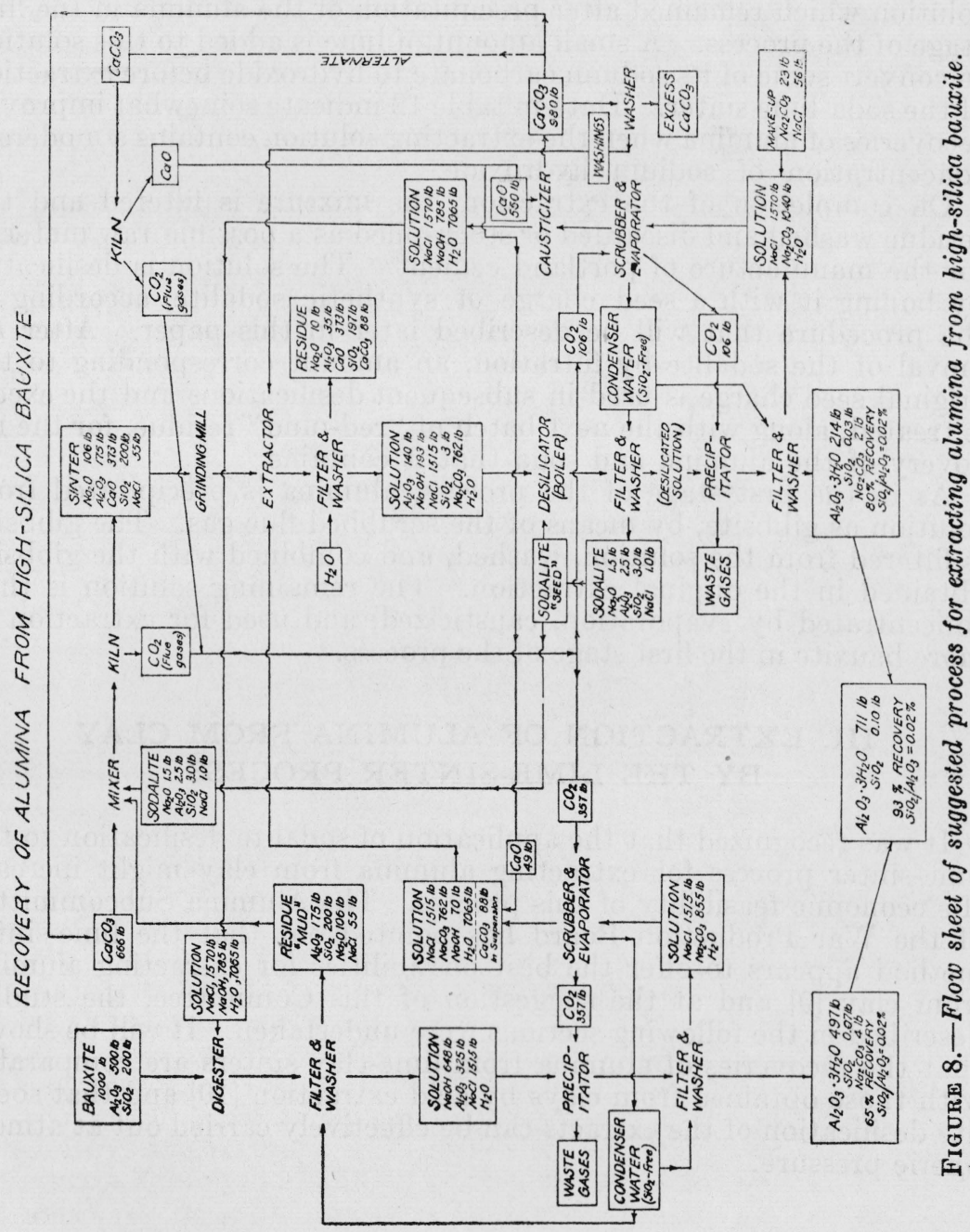

$675813-46-6$ 
The alumina may be removed from the extract by controlled precipitation with carbon dioxide in the presence of a seed charge of gibbsite. In the flow sheet the scrubbed gas is shown as the source of carbon dioxide. By passing the kiln gas into the solution, the major part of the alumina can be precipitated without undue contamination by the small amount of silica in the extract. In the flow sheet, complete precipitation of the alumina is indicated as this would be accomplished in cyclical operation of the process.

The residue from the initial extraction contains soda, alumina, silica, and sodium chloride in proportions approaching those of the mineral sodalite, as well as the relatively inert constituents of the bauxite, such as $\mathrm{Fe}_{2} \mathrm{O}_{3}$ and $\mathrm{TiO}_{2}$. Ground limestone is added to the residue to give a $\mathrm{CaO} / \mathrm{SiO}_{2}$ molar ratio of 2.0 , and the mixture is then heated to a suitable temperature to bring about clinkering or sintering. After grinding the sinter, it is extracted at $70^{\circ}$ to $80^{\circ} \mathrm{C}$ with the solution which remained after precipitation of the alumina in the first stage of the process. A small amount of lime is added to this solution to convert some of its sodium carbonate to hydroxide before extraction of the soda-lime sinter. Data in table 12 indicate somewhat improved recoveries of alumina when the extracting solution contains a moderate concentration of sodium hydroxide.

On completion of the extraction, the mixture is filtered and the residue washed and discarded or stock-piled as a possible raw material for the manufacture of portland cement. The solution is desilicated by boiling it with a seed charge of synthetic sodalite, according to the procedure that will be described later in this paper. After removal of the sodalite by filtration, an amount corresponding to the original seed charge is used in subsequent desilications and the excess is treated, along with the next batch of "red-mud" residue, for the recovery of the alumina and soda that it contains.

As in the first stage of the process, alumina is precipitated from solution as gibbsite, by means of the scrubbed flue gas. The gibbsite is filtered from the solution, washed, and combined with the gibbsite obtained in the original extraction. The remaining solution is then concentrated by evaporation, causticized, and used for extraction of more bauxite in the first stage of the process.

\section{EXTRACTION OF ALUMINA FROM CLAY BY THE LIME-SINTER PROCESS}

It was recognized that the application of sodalite desilication to the lime-sinter process for extracting alumina from clay might increase the economic feasibility of this process. The Alumina Subcommittee of the War Production Board has pointed out that the lime-sinter method appears to offer the best possibilities for extracting alumina from clay [9] and at the suggestion of this Committee, the studies described in the following sections were undertaken. It will be shown that the recoveries of alumina from lime-clay sinters are comparable with those obtained from clays by acid extraction [10] and that sodalite desilication of the extracts can be effectively carried out at atmospheric pressure. 


\section{MATERIALS AND PROCEDURE}

The raw materials were a Georgia kaolin and a ground limestone of the following compositions:

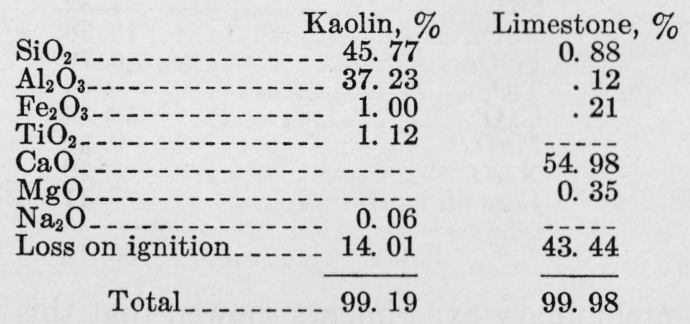

The other materials included sodium carbonate, sodium chloride, and sodium hydroxide.

Sinters were prepared from properly proportioned mixtures of the ground limestone and kaolin by burning under various conditions. Extractions of the finely powdered sinters were made with solutions containing sodium carbonate or mixtures of sodium carbonate and sodium chloride. In the preliminary experiments listed in the following section the mixtures were agitated in 750-ml Erlenmeyer flasks placed on a slow-speed shaking machine which was kept in an air thermostat. In all other experiments, extractions of the sinters were made with a high-speed stirrer. The extraction vessel was a $500-\mathrm{ml}$ three-neck flask, with the stirrer inserted in the middle neck and a thermometer and funnel for adding the sinter in the side necks. The temperature was maintained within \pm 1 degree centigrade of the values specified, by controlled heating.

On completion of the extraction, the mixtures were filtered and the residues washed with water or $\mathrm{NaCl}$ solution. In the preliminary experiments the extracts and washes were mixed, but in subsequent work they were stored separately. The combined extracts and washes were desilicated by boiling in iron containers with seed charges of synthetic sodalite, and the solutions were separated from the insoluble material by filtration.

In order to ascertain yields and the purity of the extracted alumina with respect to silica, analyses of the solutions were made for $\mathrm{Al}_{2} \mathrm{O}_{3}$ and $\mathrm{SiO}_{2}$ and, in some cases, for $\mathrm{Na}_{2} \mathrm{O}$ and $\mathrm{NaCl}$. Determinations of $\mathrm{SiO}_{2}$ were made in samples containing 5 to $10 \mathrm{~g}$ of $\mathrm{Al}_{2} \mathrm{O}_{3}$.

\section{PREPARATION OF SINTERS}

To obtain a sinter which would be free from unreactive aluminate compounds such as gehlenite, $2 \mathrm{CaO} \cdot \mathrm{Al}_{2} \mathrm{O}_{3} \cdot \mathrm{SiO}_{2}$, a mixture of ground limestone and kaolin was prepared in such proportions that, after burning, the composition of the resulting material corresponded to a point on a line joining the composition of $2 \mathrm{CaO} . \mathrm{SiO}_{2}$ and the quintuple point $5 \mathrm{CaO} .3 \mathrm{Al}_{2} \mathrm{O}_{3}, \mathrm{CaO} \cdot \mathrm{Al}_{2} \mathrm{O}_{3}$, and $2 \mathrm{CaO} . \mathrm{SiO}_{2}$ in the $\mathrm{CaO}$ $\mathrm{Al}_{2} \mathrm{O}_{3}-\mathrm{SiO}_{2}$ diagram [16]. Allowance was made for the lime and alumina required for the formation of $\mathrm{CaO} \cdot \mathrm{TiO}_{2}$ and $4 \mathrm{CaO} \cdot \mathrm{Al}_{2} \mathrm{O}_{3}$ $\mathrm{Fe}_{2} \mathrm{O}_{3}$ with any $\mathrm{TiO}_{2}$ and $\mathrm{Fe}_{2} \mathrm{O}_{3}$ in the raw materials. About 80 
pounds of this mixture were burned in a brick kiln at $1,300^{\circ}$ to $1,350^{\circ} \mathrm{C}$ for 5 hours. The composition of this product, which will be referred to as sinter $\mathrm{R}$, was

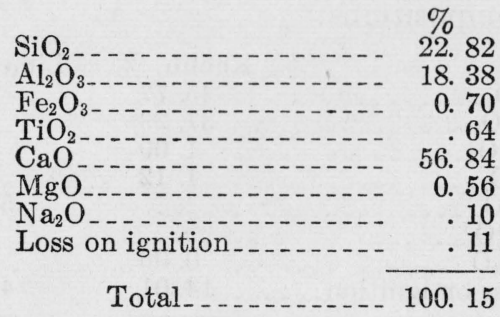

Because preliminary experiments showed that this product did not give satisfactory extractions, it was ground to an average particle size of 5 microns.

A number of small-batch sinters were prepared by burning $100-\mathrm{g}$ quantities of the original mix in a muffle until the products gave no test for free lime. This material (sinter S) was only slightly sintered and required no grinding. It contained dicalcium silicate largely in the beta form.

A third batch of lime-clay calcine (sinter T) was obtained. Details of the preparation of this material were not available. Petrographic examination of the sinter showed the presence of about three times as much gamma- as beta-dicalcium silicate. The beta-dicalcium silicate grains appeared to be surrounded by thin films of low-index, isotropic material, presumably glass. The composition of the sinter was

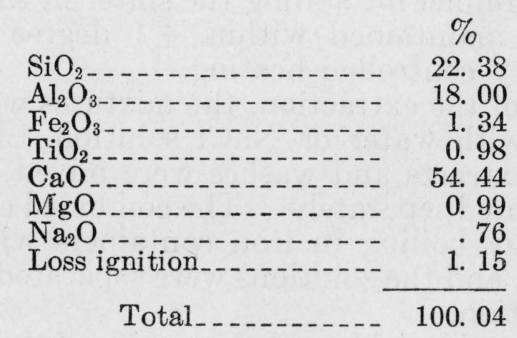

\section{EXTRACTION OF SINTERS WITH DILUTE SODIUM CARBONATE SOLUTIONS}

The extractions listed in table 13 were made on samples of sinter $\mathrm{S}$. The volume of the extracting solution was $400 \mathrm{ml}$ in all experiments and the quantity of material extracted was such that the molar ratio of $\mathrm{Na}_{2} \mathrm{CO}_{3}$ in solution to $\mathrm{Al}_{2} \mathrm{O}_{3}$ in the sinter was 2.0. The mixtures were shaken for 2 hours at the temperatures indicated in table 13, filtered, and the residues washed with $100 \mathrm{ml}$ of hot water. Some of the combined extracts and washes were then analyzed for $\mathrm{Al}_{2} \mathrm{O}_{3}$ and $\mathrm{SiO}_{2}$, giving the results shown in table 13 under the heading "Not desilicated." Other combined extracts and washes were boiled for 2 hours with seed charges consisting of $5 \mathrm{~g}$ of synthetic sodalite. After removal of the sodalite by filtration, the solutions were analyzed for $\mathrm{Al}_{2} \mathrm{O}_{3}, \mathrm{SiO}_{2}$, and in some cases, $\mathrm{Na}_{2} \mathrm{O}$. The results of determinations of $\mathrm{Al}_{2} \mathrm{O}_{3}$ and $\mathrm{SiO}_{2}$ and calculated recoveries of $\mathrm{Na}_{2} \mathrm{O}$ are given in the last five columns of table 13 . 
TABLE 13.-Extractions of sinter $S$ with dilute $\mathrm{Na}_{2} \mathrm{CO}_{3}$ solutions containing $\mathrm{NaCl}$

[Volume of extracting solution, $400 \mathrm{ml}$; time of extraction, $2 \mathrm{hr}$ ]

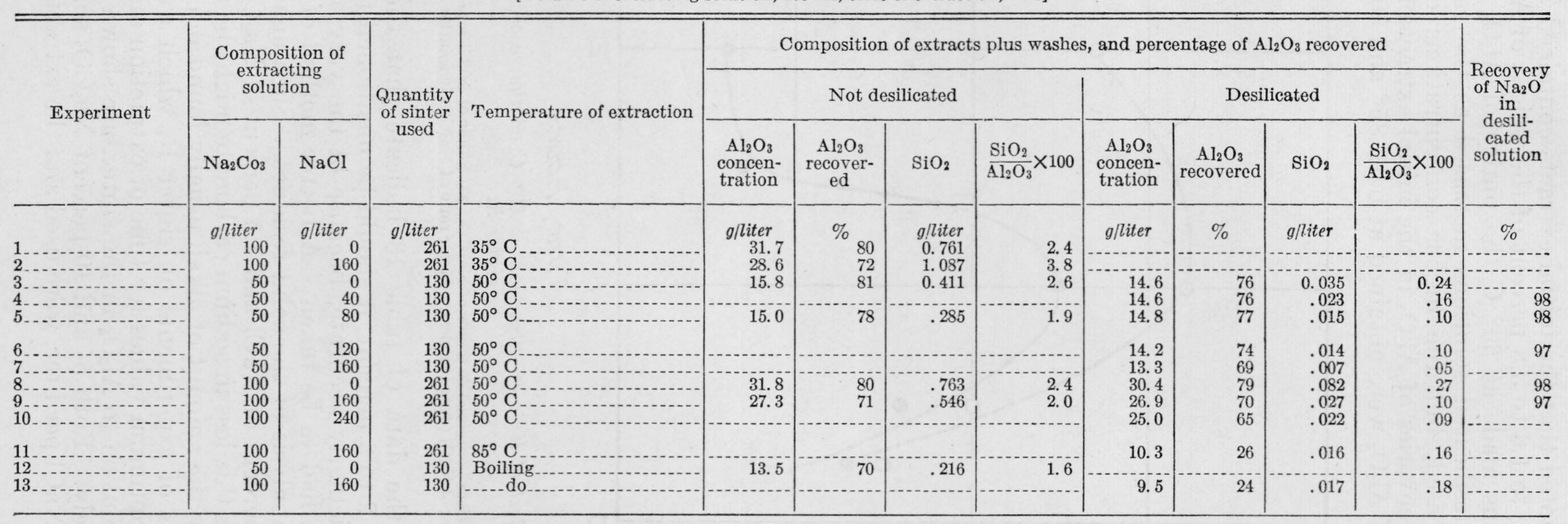


It will be noted that the initial extracts contained $\mathrm{SiO}_{2}$ in amounts corresponding to 1.6 to 3.8 percent of the weight of $\mathrm{Al}_{2} \mathrm{O}_{3}$ in solution. For extractions made at $50^{\circ} \mathrm{C}$ the purity of $\mathrm{Al}_{2} \mathrm{O}_{3}$ with respect to $\mathrm{SiO}_{2}$ in the desilicated solutions increased as the ratio of $\mathrm{NaCl}$ to $\mathrm{Na}_{2} \mathrm{CO}_{3}$ increased, but the higher concentrations of $\mathrm{NaCl}$ caused diminished recoveries of $\mathrm{Al}_{2} \mathrm{O}_{3}$ in the initial extractions. The higher extractions of $\mathrm{Al}_{2} \mathrm{O}_{3}$ were obtained at both $35^{\circ}$ and $50^{\circ} \mathrm{C}$.

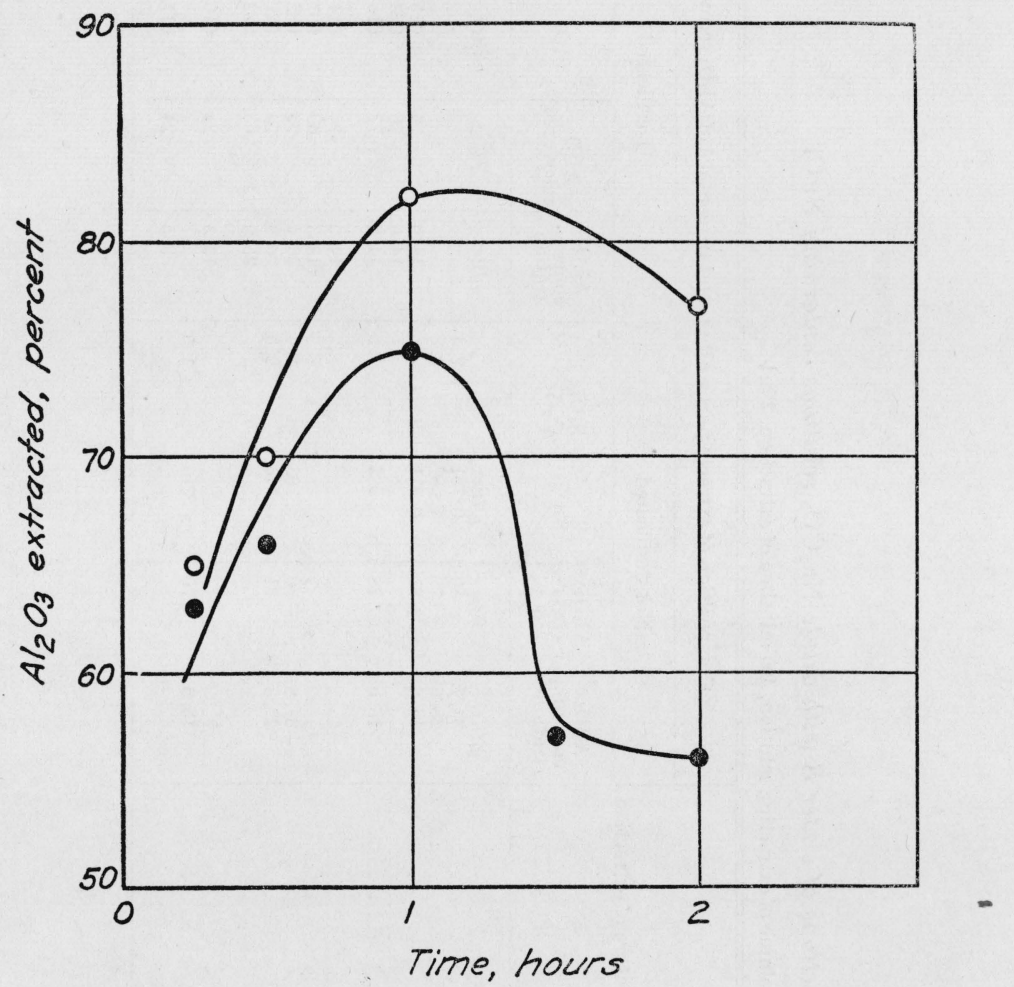

FiguRe 9.-Effect of time of extraction at $40^{\circ} C$ on the recovery of alumina from sinter $R$.

The extracting solutions contained $50 \mathrm{~g} /$ liter of $\mathrm{Na}_{2} \mathrm{CO}_{3}, 200 \mathrm{~g} /$ liter of $\mathrm{NaCl}$ (open circles); and $100 \mathrm{~g} /$ liter of $\mathrm{Na}_{2} \mathrm{CO}_{3}, 200 \mathrm{~g}$ /liter of $\mathrm{NaCl}$ (closed circles). Molar ratio of $\mathrm{Na}_{2} \mathrm{CO}_{3}$ in solution to $\mathrm{Al}_{2} \mathrm{O}_{3}$ in sinter $=2.5$

Although the data of table 13 indicate that the losses of soda amounted to 2 to 3 percent, it should be mentioned that these values are not particularly accurate, because of the very small aliquots of solution that had to be taken. A better method of measuring soda losses is by analysis of the solid residues. Such analysis indicated a loss of 0.05 percent of $\mathrm{NaCl}$ and 1.5 percent of $\mathrm{Na}_{2} \mathrm{CO}_{3}$. With some raw materials this loss in sodium carbonate might be made up, wholly or in part, by the amount of alkali usually found in clay.

The results of experiments on sinter $R$, which were made to determine the optimum values for time of extraction and molar ratio of $\mathrm{Na}_{2} \mathrm{CO}_{3}$ in solution to $\mathrm{Al}_{2} \mathrm{O}_{3}$ in the sinter, are shown in figures 9 and 10 , respectively. Both 5- and 10-percent $\mathrm{Na}_{2} \mathrm{CO}_{3}$ solutions, containing $200 \mathrm{~g}$ of $\mathrm{NaCl}$ per liter, were used and the extraction temperature 
was $40^{\circ} \mathrm{C}$. In the experiments illustrated by figure 9 the molar ratio of $\mathrm{Na}_{2} \mathrm{CO}_{3}$ in solution to $\mathrm{Al}_{2} \mathrm{O}_{3}$ in the sinter was maintained constant at 2.5.

As shown in figure 9 the optimum extraction time appears to be about 1 hour. Longer periods gave much reduced extractions for the 10-percent $\mathrm{Na}_{2} \mathrm{CO}_{3}$ solution, appreciable reductions for the 5-percent solution. It should be pointed out, however, that the optimum

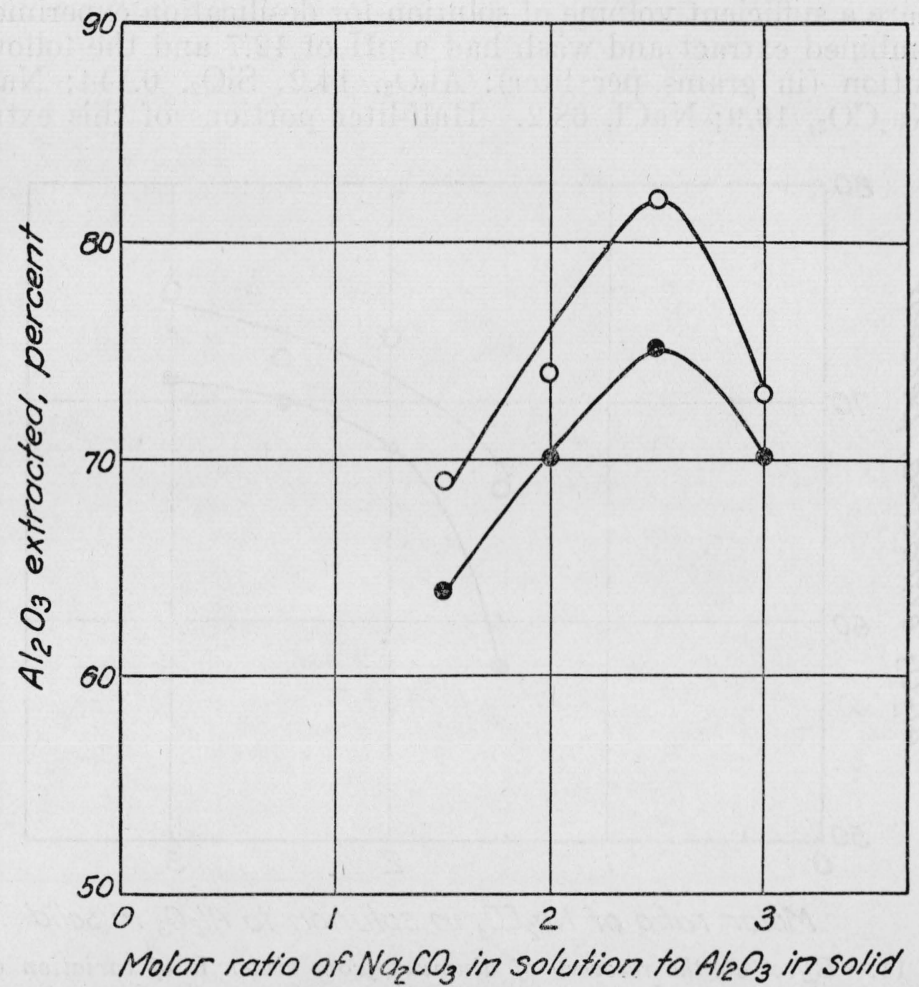

FIGURE 10.-Effect on the recovery of alumina from sinter $R$ of variation of the molar ratio of sodium carbonate in the extracting solution to alumina in the sinter.

The extracting solutions contained $50 \mathrm{~g} /$ iter of $\mathrm{Na}_{2} \mathrm{CO}_{3}, 200 \mathrm{~g} /$ liter of $\mathrm{NaCl}$ (open circles); and $100 \mathrm{~g} /$ liter of $\mathrm{Na}_{2} \mathrm{CO}_{3}, 200 \mathrm{~g} /$ liter of $\mathrm{NaCl}$ (closed circles). Mixtures shaken for $1 \mathrm{hr}$ at $40^{\circ} \mathrm{C}$.

time of extraction will be determined by the type of agitator used as well as by the nature of the sinter. In a later section it will be shown that when more vigorous agitation was employed the optimum extraction period was considerably less than that indicated in figure 9 .

Figure 10 shows that a molar ratio of $2.5 \mathrm{Na}_{2} \mathrm{CO}_{3} / \mathrm{Al}_{2} \mathrm{O}_{3}$ gave the highest extractions of alumina from sinter $\mathrm{R}$, with a marked decrease occurring at a $3 . \mathrm{ONa}_{2} \mathrm{CO}_{3} / \mathrm{Al}_{2} \mathrm{O}_{3}$ molar ratio.

The effect of excess sodium hydroxide on extractions of alumina from sinter $\mathrm{R}$ is shown by comparison of figures 10 and 11 . The compositions of the mixtures in the experiments illustrated by figure 11 were the same as those on which figure 10 is based, except that they contained a quantity of added $\mathrm{NaOH}$, which corresponded to 
10 percent of the weight of $\mathrm{Na}_{2} \mathrm{CO}_{3}$ in the initial solutions. Poorer extractions were obtained in these experiments than in comparable ones shown in figure 10, except where the molar ratio of $\mathrm{Na}_{2} \mathrm{CO}_{3}$ to $\mathrm{Al}_{2} \mathrm{O}_{3}$ was 3.0 .

\section{DESILICATION OF DILUTE SODIUM ALUMINATE SOLUTIONS}

An extraction of sinter $\mathrm{R}$ was made in the small pilot plant in order to prepare a sufficient volume of solution for desilication experiments. The combined extract and wash had a $\mathrm{pH}$ of 12.7 and the following composition (in grams per liter): $\mathrm{Al}_{2} \mathrm{O}_{3}, 14.2 ; \mathrm{SiO}_{2}, 0.144 ; \mathrm{NaOH}$, $18.6 ; \mathrm{Na}_{2} \mathrm{CO}_{3}, 10.9 ; \mathrm{NaCl}, 68.2$. Half-liter portions of this extract,

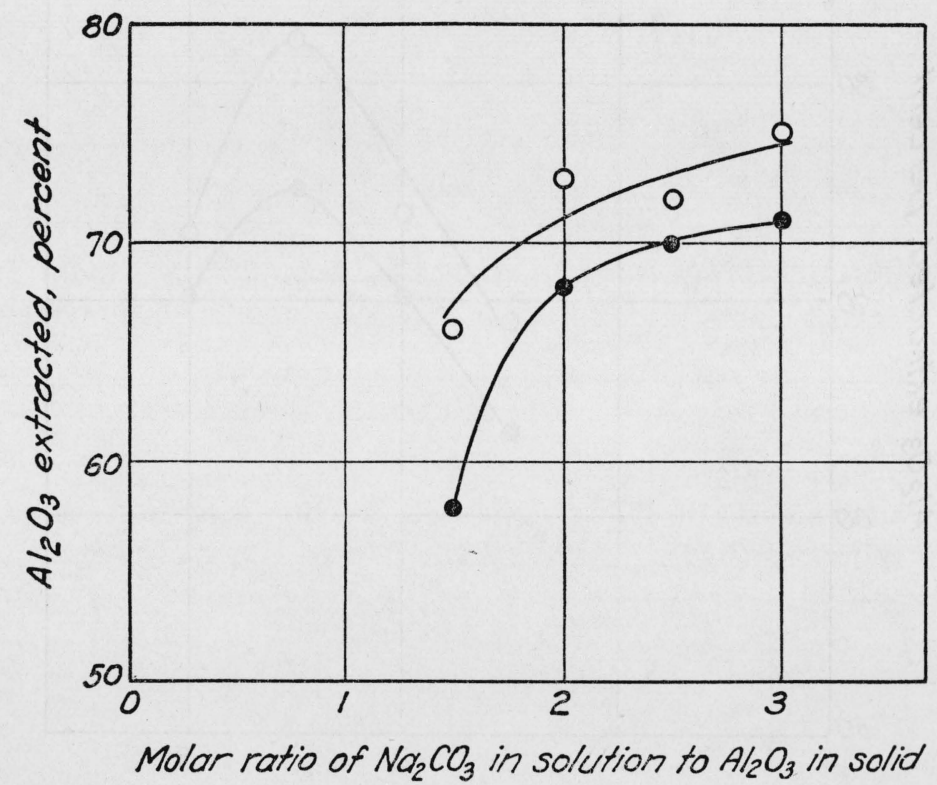

FIGURE 11.-Effect on the recovery of alumina from sinter $R$ of variation of the molar ratio of sodium carbonate in the extracting solution to alumina in the sinter, in the presence of sodium hydroxide.

The extracting solutions contained $50 \mathrm{~g} /$ liter of $\mathrm{Na}_{2} \mathrm{CO}_{3}, 5 \mathrm{~g}$ /liter of $\mathrm{NaOH}, 200 \mathrm{~g} /$ liter of $\mathrm{NaCl}$ (open circles); and $100 \mathrm{~g} /$ liter of $\mathrm{Na}_{2} \mathrm{CO}_{3}, 10 \mathrm{~g} /$ liter of $\mathrm{NaOH}, 200 \mathrm{~g} / \mathrm{liter}$ of $\mathrm{NaCl}$ (closed circles). Mixtures shaken for $1 \mathrm{hr}$ at $40^{\circ} \mathrm{C}$.

with and without added sodium chloride, were boiled with seed charges of synthetic sodalite prepared in the autoclave from gibbsite plus silica gel. The seed was removed by filtration, and the solutions were analyzed. The results are summarized in table 14 .

When the quantity of seed added was $2 \mathrm{~g} /$ liter, the greatest lowering in $\mathrm{SiO}_{2}$ concentration was obtained after boiling for 2 to 3 hours, as shown in experiments 2 to 5 . This quantity of seed is insufficient, however, and if the amount of sodalite is increased to $10 \mathrm{~g} /$ /iter, the desilication proceeds further, as shown in experiment 6 . Increases in the concentration of $\mathrm{NaCl}$ in solution also bring about decreases in the $\mathrm{SiO}_{2}$ concentration (experiments 7 to 10). The values of the $\mathrm{SiO}_{2} / \mathrm{Al}_{2} \mathrm{O}_{3}$ ratio, both in the solution and in the alumina after complete precipitation by means of carbon dioxide, are shown in figure 12 . 
TABLE 14.-Desilication (by boiling with synthetic sodalite) of dilute sodium aluminate solution containing $14.2 \mathrm{~g}$ of $\mathrm{Al}_{2} \mathrm{O}_{3}, 0.144 \mathrm{~g}$ of $\mathrm{SiO}_{2}$ per liter, arid various amounts of sodium chloride

\begin{tabular}{|c|c|c|c|c|c|c|}
\hline \multirow{2}{*}{ Experiment } & \multirow{2}{*}{$\begin{array}{l}\mathrm{NaCl} \text { in } \\
\text { extracting } \\
\text { solution }\end{array}$} & \multirow{2}{*}{$\begin{array}{l}\text { Amount of } \\
\text { seed added }\end{array}$} & \multirow{2}{*}{$\begin{array}{l}\text { Time of } \\
\text { boiling }\end{array}$} & \multirow{2}{*}{$\begin{array}{l}\mathrm{SiO}_{2} \text { in } \\
\text { solution }\end{array}$} & \multicolumn{2}{|c|}{$\frac{\mathrm{SiO}_{2}}{\mathrm{Al}_{2} \mathrm{O}_{3}} \times 100 \mathrm{in}-$} \\
\hline & & & & & Solution & $\begin{array}{c}\text { Precipi- } \\
\text { tated } \mathrm{Al}_{2} \mathrm{O}_{3}\end{array}$ \\
\hline $\begin{array}{l}1 \\
2 \\
3\end{array}$ & $\begin{array}{r}\text { g/liter } \\
68 \\
68 \\
68 \\
68 \\
68\end{array}$ & $\begin{array}{r}\text { g/liter } \\
0 \\
2 \\
2 \\
2 \\
2 \\
2\end{array}$ & $\begin{array}{l}\text { hr } \\
0.5 \\
1 \\
2 \\
3\end{array}$ & $\begin{array}{r}\text { g/liter } \\
0.1440 \\
.0442 \\
.0376 \\
.0238 \\
.0238\end{array}$ & $\begin{array}{l}1.01 \\
0.31 \\
.26 \\
.17 \\
.17\end{array}$ & 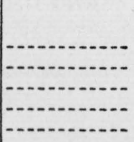 \\
\hline $\begin{array}{l}6 \\
7 \\
8 \\
9\end{array}$ & $\begin{array}{r}68 \\
114 \\
162 \\
204 \\
243\end{array}$ & $\begin{array}{l}10 \\
10 \\
10 \\
10 \\
10\end{array}$ & $\begin{array}{l}2 \\
2 \\
2 \\
2 \\
2\end{array}$ & $\begin{array}{l}.0110 \\
.0100 \\
.0049 \\
.0047 \\
.0024\end{array}$ & $\begin{array}{l}.08 \\
.07 \\
.035 \\
.03 \\
.02\end{array}$ & $\begin{array}{l}0.10 \\
.07 \\
.05 \\
.04 \\
02\end{array}$ \\
\hline
\end{tabular}

The point at zero concentration of $\mathrm{NaCl}$ is taken from experiment 3 of table 13.

To obtain information on the effect of treating larger quantities of solution, a 26-liter portion of the undesilicated extract containing $200 \mathrm{~g}$ of $\mathrm{NaCl}$ per liter was boiled for 2 hours with $260 \mathrm{~g}$ of sodalite $(10 \mathrm{~g} /$ liter). The sodalite was removed by filtration and carbon dioxide was passed into the boiling solution in the presence of gibbsite seed. Precipitation was continued for 8 hours when only $0.1 \mathrm{~g}$ of $\mathrm{Al}_{2} \mathrm{O}_{3}$ per liter remained in solution. After filtration, washing, and drying, analysis of the gibbsite showed its $\mathrm{SiO}_{2}$ content to be 0.014 percent (on the basis of the anhydrous $\mathrm{Al}_{2} \mathrm{O}_{3}$ ).

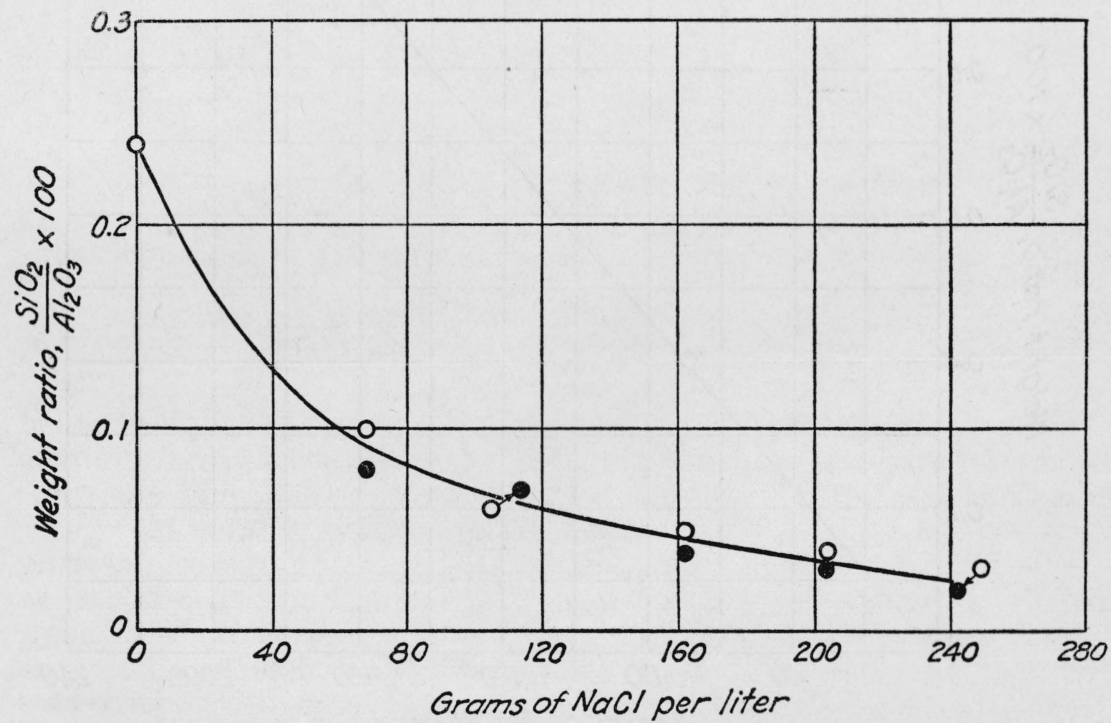

FIgURE 12.-Effect of sodium chloride concentration on the sodalite desilication of an extract, from sinter $R$, containing $14 \mathrm{~g} /$ liter of $\mathrm{Al}_{2} \mathrm{O}_{3}$ and $0.14 \mathrm{~g} /$ liter of $\mathrm{SiO}_{2}$.

Values of $\frac{\mathrm{SiO}_{2}}{\mathrm{Al}_{3} \mathrm{O}_{3}} \times 100$ determined by analysis of solutions (closed circles) and of hydrated alumina after complete precipitation from solution (open circles). 
A few experiments were made in which various amounts of sodium hydroxide were added to portions of the extract described in the first paragraph of section $\mathrm{C}$. After the $\mathrm{pH}$ of the resulting solutions had been measured, $500-\mathrm{ml}$ portions were boiled for 2 hours with $5-\mathrm{g}$ quantities of sodalite, the sodalite removed by filtration, and the

TABLE 15.-Effect of sodium hydroxide concentration on the desilication of 500-ml portions of a sodium aluminate solution containing approximately $14 \mathrm{~g}$ of $\mathrm{Al}_{2} \mathrm{O}_{3}$ and $0.14 \mathrm{~g}$ of $\mathrm{SiO}_{2}$ per liter

[Desilication effected by boiling with $5 \mathrm{~g}$ of synthetic sodalite for $2 \mathrm{hr}$ ]

\begin{tabular}{|c|c|c|c|c|c|}
\hline \multirow{2}{*}{ Experiment } & \multirow{2}{*}{$\begin{array}{l}\mathrm{NaOH} \text { in } \\
\text { extracting } \\
\text { solution }\end{array}$} & \multirow{2}{*}{$\mathrm{pH}$} & \multicolumn{3}{|c|}{$\begin{array}{c}\text { Composition of solution after } \\
\text { desilication }\end{array}$} \\
\hline & & & $\mathrm{Al}_{2} \mathrm{O}_{3}$ & $\mathrm{SiO}_{2}$ & $\frac{\mathrm{SiO}_{2}}{\mathrm{Al}_{2} \mathrm{O}_{3}} \times 100$ \\
\hline $\begin{array}{l}1 \\
2\end{array}$ & $\begin{array}{c}\text { g/liter } \\
18.6 \\
69 \\
119 \\
169 \\
219\end{array}$ & $\begin{array}{l}12.7 \\
13.4 \\
14.0 \\
14.2 \\
14.4\end{array}$ & $\begin{array}{r}\text { g/liter } \\
14.2 \\
14.0 \\
14.5 \\
14.8 \\
14.7\end{array}$ & $\begin{array}{c}\text { g/liter } \\
0.011 \\
.056 \\
.097 \\
.163 \\
.174\end{array}$ & $\begin{array}{r}0.08 \\
.40 \\
.67 \\
1.10 \\
1.18\end{array}$ \\
\hline
\end{tabular}

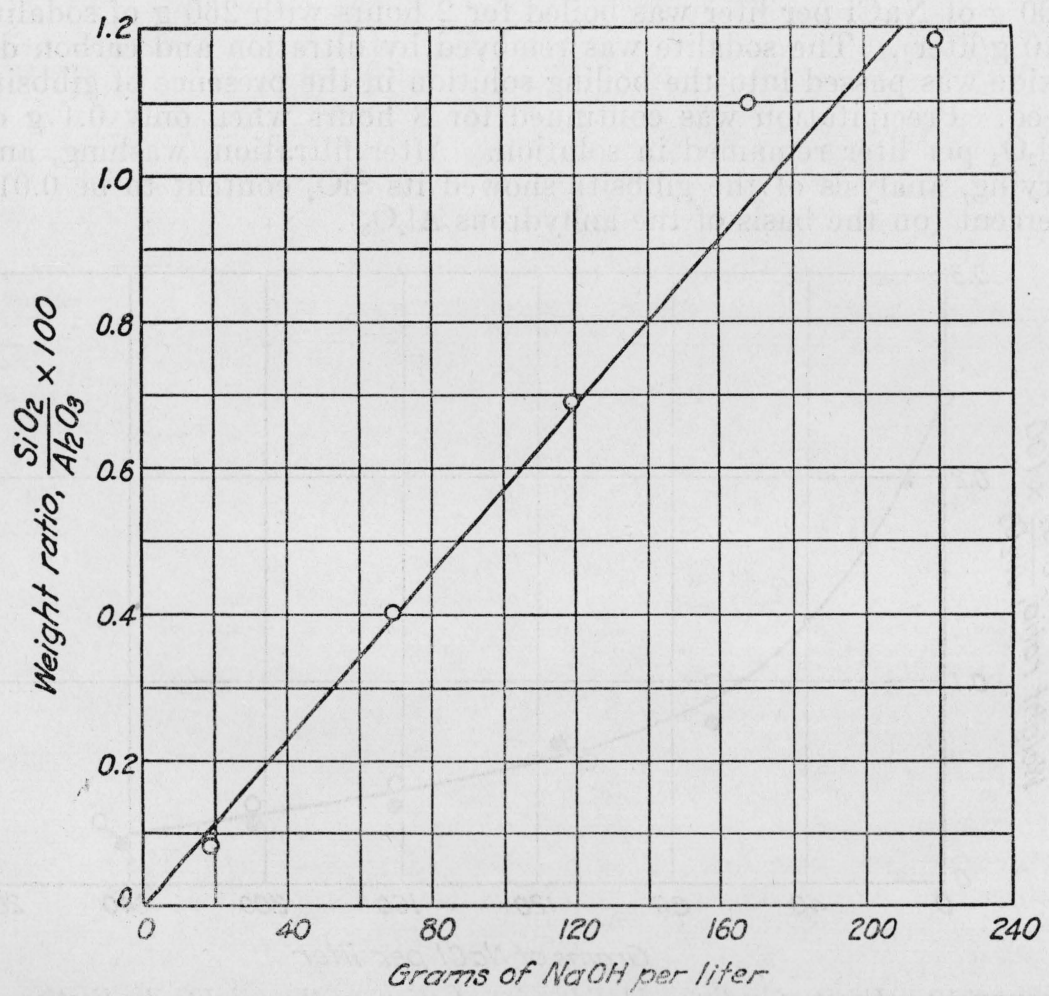

Figure 13.-Effect of sodium hydroxide concentration on the sodalite desilication of an extract, from sinter $R$, containing approximately $14 \mathrm{~g} /$ liter of $\mathrm{Al}_{2} \mathrm{O}_{3}$ and 0.14 g/liter of $\mathrm{SiO}_{2}$. 
solutions analyzed for $\mathrm{Al}_{2} \mathrm{O}_{3}$ and $\mathrm{SiO}_{2}$. The data, given in table 15 and figure 13, show that desilication becomes less efficient as the sodium hydroxide concentration increases. Decomposition of the sodalite seed in the solutions containing the larger amounts of $\mathrm{NaOH}$ is indicated by increases in the $\mathrm{Al}_{2} \mathrm{O}_{3}$ contents of the solutions following desilication.

Thugutt [11] synthesized sodalite by autoclaving kaolinite at $212^{\circ} \mathrm{C}$ with a solution containing $\mathrm{NaCl}$ and $\mathrm{NaOH}$. Other investigators have reported that sodalite is formed in fusions of large excesses of $\mathrm{NaCl}$ with (a) nephelite [12]; (b) mixtures of kaolinite and $\mathrm{Na}_{2} \mathrm{CO}_{3}$ [13]; or (c) mixtures of $\mathrm{SiO}_{2}, \mathrm{Al}_{2} \mathrm{O}_{3}$, and $\mathrm{NaOH}$ [14].

As it had been observed in this study that some sodalite preparations were more effective desilicating agents than others, the various methods of preparation given in table 16 were tried.

TABLE 16.-Comparison of desilication effectiveness of sodalites prepared by various methods

[Initial solution contained $18.3 \mathrm{~g}$ of $\mathrm{Al}_{2} \mathrm{O}_{3}$ and $0.146 \mathrm{~g}$ of $\mathrm{SiO}_{2}$ per liter. Desilication effected by boiling with sodalites for $1 \mathrm{hr}$ ]

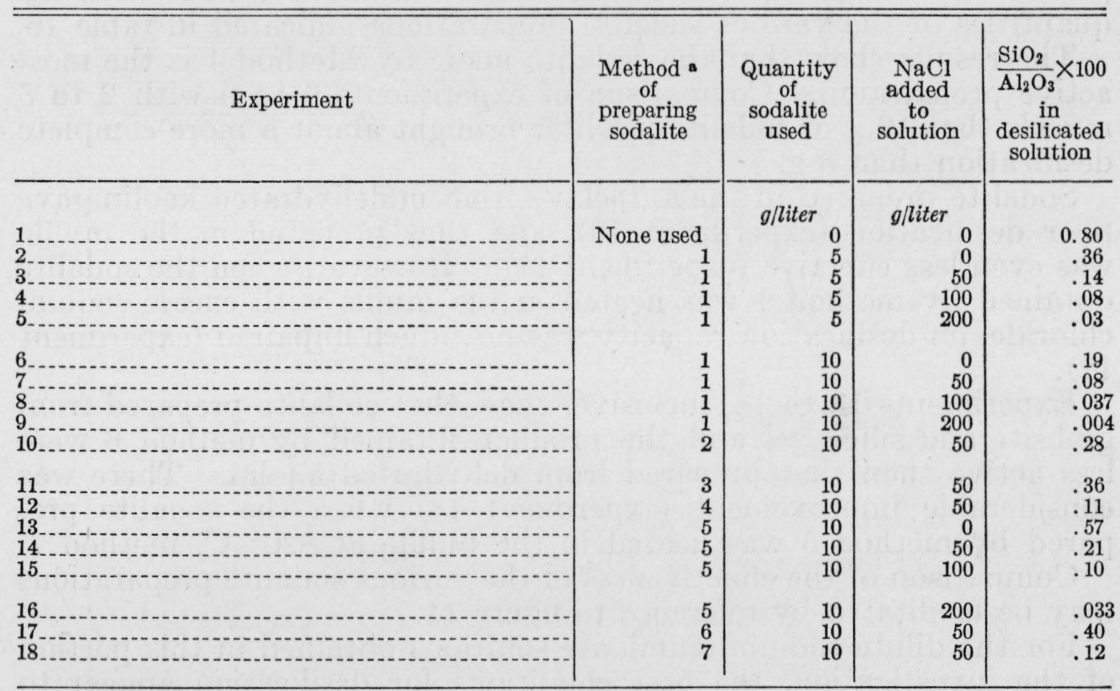

= (1) Dehydrated kaolin $+\mathrm{NaOH}+\mathrm{NaCl}+\mathrm{H}_{2} \mathrm{O}$ heated in autoclave at $150^{\circ} \mathrm{C}$ for 4 days.

(2) Undehydrated kaolin $+\mathrm{NaOH}+\mathrm{NaCl}+\mathrm{H}_{2} \mathrm{O}$ heated in autoclave at $150^{\circ} \mathrm{C}$ for 4 days.

(3) Undehydrated kaolin $+\mathrm{Na}_{2} \mathrm{CO}_{3}+\mathrm{NaCl}$ heated in muffle at $820^{\circ} \mathrm{C}$ for 16 hours.

(4) Preparation (1), above, heated with excess NaCl in muffle at $820^{\circ} \mathrm{C}$ for 16 hours.

(5) Gibbsite+silica gel+NaOH $+\mathrm{NaCl}+\mathrm{H}_{2} \mathrm{O}$ heated in autoclave at $150^{\circ} \mathrm{C}$ for 4 days.

(6) Gibbsite+silica gel $+\mathrm{Na}_{2} \mathrm{CO}_{3}+\mathrm{NaCl}$ heated in muffle at $820^{\circ} \mathrm{C}$ for 16 hours.

(7) Preparation (5), above, heated with excess $\mathrm{NaCl}$ in muffle at $820^{\circ} \mathrm{C}$ for 16 hours.

In these experiments, the quantity of sodium hydroxide or sodium carbonate used was in moderate excess of the amount theoretically required to form sodalite, and the sodium chloride was present in greater excess. As an example of the procedure, a batch of sodalite was prepared by method 1 as follows:

The kaolin was first activated by heating it at $700^{\circ} \mathrm{C}$ for 1 hour. A batch of $200 \mathrm{~g}$ of this dehydrated kaolin, $150 \mathrm{~g}$ of $\mathrm{NaCl}, 100 \mathrm{~g}$ of $\mathrm{NaOH}$, and $400 \mathrm{ml}$ of water, was kept at $150^{\circ} \mathrm{C}$ in an autoclave for 4 
days. The product was then removed, washed with hot water, and dried at $110^{\circ} \mathrm{C}$. Analysis showed the following composition:

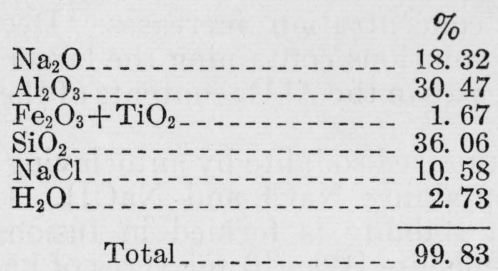

Ignoring the $\mathrm{Fe}_{2} \mathrm{O}_{3}+\mathrm{TiO}_{2}$, this analysis corresponds to the following molar ratios: $0.99 \mathrm{Na}_{2} \mathrm{O}: 1.00 \mathrm{Al}_{2} \mathrm{O}_{3}: 2.01 \mathrm{SiO}_{2}: 0.61 \mathrm{NaCl}: 0.51 \mathrm{H}_{2} \mathrm{O}$, in good agreement with the theoretical molar ratios of sodalite: $1.00 \mathrm{Na}_{2} \mathrm{O}$ : $1.00 \mathrm{Al}_{2} \mathrm{O}_{3}: 2.00 \mathrm{SiO}_{2}: 0.67 \mathrm{NaCl}$.

To compare the effectiveness of the various sodalite preparations, a large quantity of sodium aluminate solution containing $18.3 \mathrm{~g}$ of $\mathrm{Al}_{2} \mathrm{O}_{3}$ and $0.146 \mathrm{~g}$ of $\mathrm{SiO}_{2}$ per liter was prepared by extraction of sinter $R$. Various amounts of sodium chloride were dissolved in $400-\mathrm{ml}$ portions of this extract, and these were boiled for 1 hour with the quantities of the various sodalite preparations indicated in table 16.

The results show that the sodalite made by Method 1 is the most active preparation. Comparison of experiments 6 to 9 with 2 to 5 reveals that $10 \mathrm{~g}$ of sodalite per liter brought about a more complete desilication than $5 \mathrm{~g}$.

Sodalite prepared in the autoclave from undehydrated kaolin gave poor desilication (experiment 10), and that prepared in the muffle was even less effective (experiment 11). However, when the sodalite obtained by method 1 was heated in the muffle with excess sodium chloride, its desilication capacity was not much impaired (experiment 12).

Experiments 13 to 18, inclusive, show that sodalite prepared from gibbsite and silica gel and the product obtained by method 6 were less active than that prepared from dehydrated kaolin. There was considerable improvement (experiment 18) when the sodalite prepared by method 5 was heated in the muffle at $820^{\circ} \mathrm{C}$, method 7 .

Comparison of the effectiveness of the various sodalite preparations may be facilitated by reference to figure 14 .

For the dilute sodium aluminate solutions obtained in this portion of the investigation, the best conditions for desilication appear to require a concentration of sodium chloride of $200 \mathrm{~g} /$ liter and boiling for 1 hour with $10 \mathrm{~g}$ of sodalite seed per liter prepared in the autoclave from dehydrated kaolin. Under these conditions the concentration of silica in solution can be reduced to less than 0.01 percent of the alumina concentration.

\section{EXTRACTION OF SINTERS WITH CONCENTRATED SODIUM CARBONATE SOLUTIONS}

All extractions described in this and following sections were made with high-speed stirring. The extraction mixtures were $100-\mathrm{ml}$ portions of solutions containing $210 \mathrm{~g}$ of sodium carbonate per liter and various amounts of sodium chloride. The quantity of sinter added was such that the molar ratio of $\mathrm{Na}_{2} \mathrm{CO}_{3}$ in solution to $\mathrm{Al}_{2} \mathrm{O}_{3}$ in the sinter was 2.0. At the end of each extraction the residue was 
filtered off and washed with a solution containing the same concentration of sodium chloride as that in the original extraction. A $100-\mathrm{ml}$ portion of this solution was used to wash the residue on the filter. The residue was then subjected to two successive repulpings, for 3 minutes each time, in 200-ml portions of the wash solution. Analyses of the combined extracts and washes were made for $\mathrm{Al}_{2} \mathrm{O}_{3}$ and also for $\mathrm{SiO}_{2}$ in some cases.

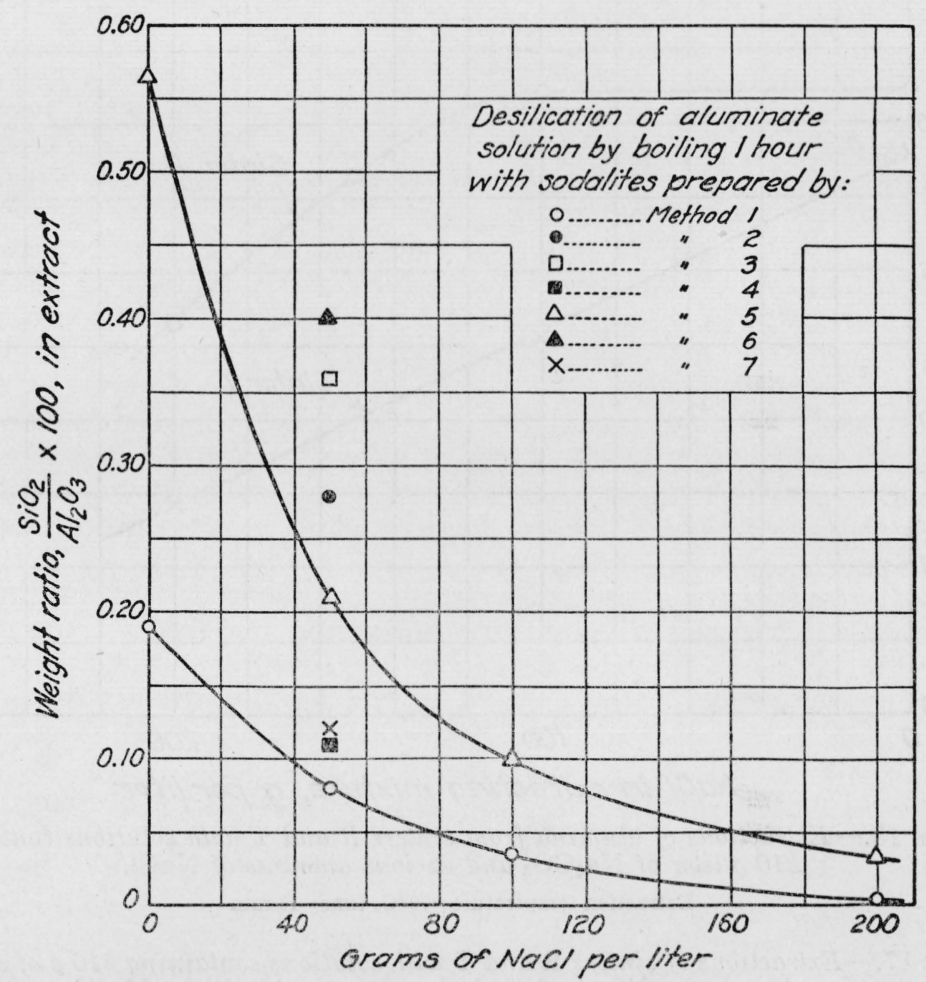

FIGURE 14.-Comparison of effectiveness of various sodalite preparations (described in table 16) in desilicating an extract, from sinter $R$, containing $18 \mathrm{~g} /$ liter of $\mathrm{Al}_{2} \mathrm{O}_{3}$ and $0.15 \mathrm{~g} /$ liter of $\mathrm{SiO}_{2}$.

Figure 15 is based on data in table 17 for the 10-minute extractions of the sinters at $70^{\circ} \mathrm{C}$. It shows that the extraction of alumina from sinter $R$, though considerably diminished at a sodium chloride concentration of $200 \mathrm{~g} /$ liter, is not affected adversely at $100 \mathrm{~g}$ of $\mathrm{NaCl}$ per liter. The recovery of alumina from sinter $\mathrm{T}$, however, shows an approximately linear decrease as the $\mathrm{NaCl}$ concentration increases from 0 to $200 \mathrm{~g} /$ liter. Table 17 shows that variations from an extraction time of 10 minutes or temperature of $70^{\circ} \mathrm{C}$ did not improve the recoveries appreciably. No beneficial results were obtained by prolonged grinding of sinter $\mathrm{T}$.

As mentioned in the preceding section, the dicalcium silicate in sinter $\mathrm{T}$ was present as a mixture of the gamma and beta modifications, and grains of the latter were surrounded by glassy films. Sinter R, however, was practically free of beta-dicalcium silicate and glass. It 
was thought that the difference in behavior of the sinters might be due in part to these factors, particularly to the presence of the reactive beta-dicalcium silicate in sinter $\mathrm{T}$, which might interfere with the reaction between sodium carbonate and calcium aluminate. Accordingly, an annealing procedure for eliminating glass and beta-dicalcium silicate from the sinter was investigated.

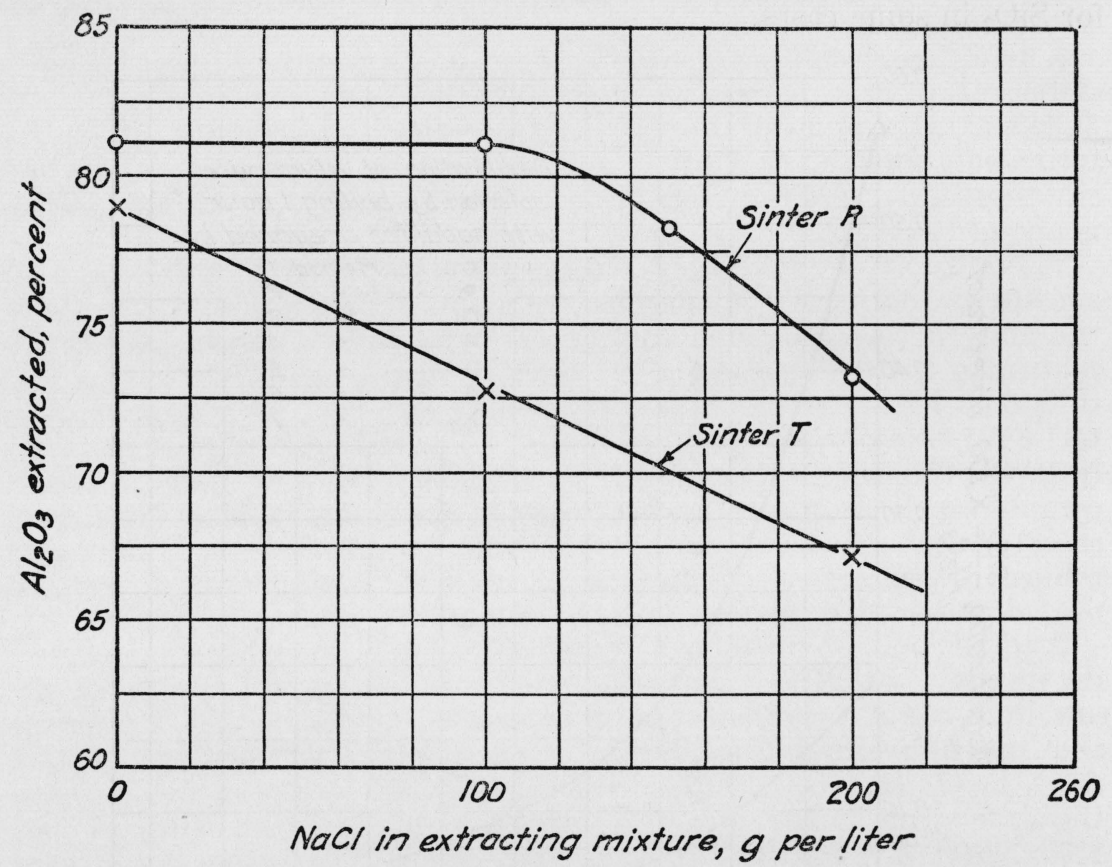

Figure 15.-Extractions of alumina from sinters $R$ and $T$ with solutions containing $210 \mathrm{~g} /$ liter of $\mathrm{Na}_{2} \mathrm{CO}_{3}$ and various amounts of $\mathrm{NaCl}$.

Extraction temperature $=70^{\circ} \mathrm{C}$; time $=10 \mathrm{~min}$

$\mathrm{T}_{\mathrm{ABLE}}$ 17.-Extractions of sinters $\mathrm{R}$ and $\mathrm{T}$ with solutions containing $210 \mathrm{~g}$ of sodium carbonate per liter and various amounts of sodium chloride

[Molar ratio of $\mathrm{Na}_{2} \mathrm{CO}_{3}$ in solution to $\mathrm{Al}_{2} \mathrm{O}_{3}$ in sinter=2.0. High-speed stirring.]

\begin{tabular}{|c|c|c|c|c|c|c|}
\hline Experiment & Sinter & $\begin{array}{l}\text { Quantity } \\
\text { of sinter } \\
\text { extracted }\end{array}$ & $\begin{array}{l}\mathrm{NaCl} \text { in } \\
\text { extracting } \\
\text { solution }\end{array}$ & $\begin{array}{l}\text { Tempera- } \\
\text { ture of } \\
\text { extraction }\end{array}$ & $\begin{array}{l}\text { Time of } \\
\text { extraction }\end{array}$ & $\underset{\text { recovery }}{\mathrm{Al}_{2} \mathrm{O}_{3}}$ \\
\hline 3 4 & $\begin{array}{l}\mathrm{R} \\
\mathrm{R} \\
\mathrm{R} \\
\mathrm{R} \\
\mathrm{R}\end{array}$ & $\begin{array}{r}\text { g/liter } \\
550 \\
550 \\
550 \\
550 \\
550\end{array}$ & $\begin{array}{r}\text { glliter } \\
0 \\
100 \\
100 \\
100 \\
150\end{array}$ & $\begin{array}{r}{ }^{\circ} C \\
70 \\
70 \\
70 \\
70 \\
70\end{array}$ & $\min \begin{array}{r}10 \\
10 \\
15 \\
20 \\
10\end{array}$ & $\begin{array}{r}\% \\
81.1 \\
81.0 \\
81.8 \\
79.2 \\
78.2\end{array}$ \\
\hline $\begin{array}{l}6 \\
7 \\
8 \\
9\end{array}$ & $\begin{array}{l}\mathrm{R} \\
\mathrm{T} \\
\mathrm{T} \\
\mathrm{T} \\
\mathrm{T}\end{array}$ & $\begin{array}{l}550 \\
561 \\
561 \\
561 \\
561\end{array}$ & $\begin{array}{r}200 \\
0 \\
100 \\
100 \\
200\end{array}$ & $\begin{array}{l}70 \\
70 \\
70 \\
70 \\
70\end{array}$ & $\begin{array}{r}10 \\
10 \\
5 \\
10 \\
10\end{array}$ & $\begin{array}{l}73.2 \\
78.9 \\
72.0 \\
72.7 \\
67.0\end{array}$ \\
\hline 12 & $\begin{array}{l}\mathrm{T} \\
\mathrm{T} \\
\mathrm{T} \\
\mathrm{T} \\
\mathrm{T}\end{array}$ & $\begin{array}{l}561 \\
561 \\
561 \\
561 \\
561\end{array}$ & $\begin{array}{r}200 \\
200 \\
0 \\
100 \\
100\end{array}$ & $\begin{array}{l}70 \\
40 \\
80 \\
80 \\
90\end{array}$ & $\begin{array}{r}30 \\
10 \\
5 \\
5 \\
5\end{array}$ & $\begin{array}{l}66.1 \\
61.5 \\
76.3 \\
73.5 \\
76.4\end{array}$ \\
\hline
\end{tabular}




\section{ANNEALING OF SINTERS}

Lerch and coworkers [15] have shown that complete crystallization of cement clinkers may be induced by heating them to $1,400^{\circ} \mathrm{C}$ and allowing the temperature to drop slowly to a value below the solidus in the system. Such "annealed" products were found to be practically free from glass and to contain dicalcium silicate exclusively in the gamma form.

The alumina content of the clinkers studied by Lerch and Brownmiller [15] was distributed between the compounds $3 \mathrm{CaO} \cdot \mathrm{Al}_{2} \mathrm{O}_{3}$, $5 \mathrm{CaO} \cdot 3 \mathrm{Al}_{2} \mathrm{O}_{3}$, and $4 \mathrm{CaO} \cdot \mathrm{Al}_{2} \mathrm{O}_{3} \cdot \mathrm{Fe}_{2} \mathrm{O}_{3}$. The temperature of liquid formation when $\mathrm{CaO} \cdot \mathrm{Al}_{2} \mathrm{O}_{3}$ is substituted for $3 \mathrm{CaO} \cdot \mathrm{Al}_{2} \mathrm{O}_{3}$, as in the sinters studied in this investigation, is unknown but in all probability is above $1,200^{\circ} \mathrm{C}$.

Accordingly, to eliminate the glassy material and beta-dicalcium silicate as completely as possible from sinter T, a 3-pound sample of the material was reheated and annealed. This was accomplished by reburning the sinter at $1,300^{\circ} \mathrm{C}$ for 1 hour in a gas-fired furnace and then causing the temperature of the charge to drop at a uniform rate to $1,200^{\circ} \mathrm{C}$ over a period of $1 \frac{1}{2}$ hours. The charge was then removed from the furnace and allowed to cool rapidly, whereupon it "dusted" completely because of the inversion of the beta form of dicalcium silicate to the gamma form. A 3-pound batch of sinter $\mathrm{R}$ was also reburned and annealed similarly. In the following section the annealed sinters will be designated as $R_{a}$ and $T_{a}$, respectively.

Another portion of sinter $\mathrm{T}$ was reburned and annealed after adjusting its composition. It had been noted that this sinter had a relatively low lime content compared with sinter R. Thus, after allowing for the lime and alumina required to form $2 \mathrm{CaO} . \mathrm{SiO}_{2}, \mathrm{CaO} . \mathrm{TiO}_{2}, 4 \mathrm{CaO}$. $\mathrm{Al}_{2} \mathrm{O}_{3} \cdot \mathrm{Fe}_{2} \mathrm{O}_{3}$, and $\mathrm{Na}_{2} \mathrm{O} \cdot \mathrm{Al}_{2} \mathrm{O}_{3}$ with the $\mathrm{SiO}_{2}, \mathrm{TiO}_{2}, \mathrm{Fe}_{2} \mathrm{O}_{3}$, and $\mathrm{Na}_{2} \mathrm{O}$ in the sinters, the molar ratio of residual lime to alumina in sinter $\mathrm{T}$ was 1.15 , whereas in sinter $\mathrm{R}$ it was 1.30 . Sinter $\mathrm{T}$ was therefore mixed with 2 percent of added lime, reburned, and annealed as before. Analysis of the product, which will be referred to in the following section as sinter $\mathrm{T}^{\prime}{ }_{\mathrm{a}}$, gave the following composition:

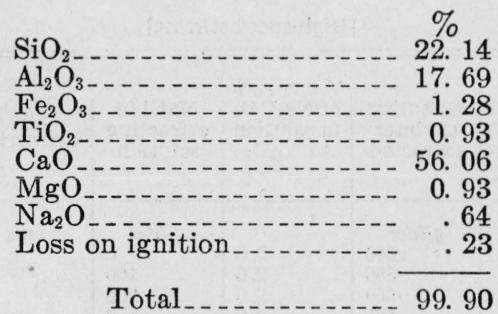

All of the annealed sinters were extremely fine-grained and passed completely through a No. 200 sieve. Petrographic examinations indicated that they were free of glass and beta-dicalcium silicate.

\section{EXTRACTION OF ANNEALED SINTERS WITH CONCENTRATED SODIUM CARBONATE SOLUTIONS}

Samples of sinter $T_{a}$, which had been annealed without adjustment of composition, were extracted at $70^{\circ}$ and $80^{\circ} \mathrm{C}$ with solutions containing $210 \mathrm{~g}$ of $\mathrm{Na}_{2} \mathrm{CO}_{3}$ per liter, with and without added $\mathrm{NaCl}$. 
Table 18 shows that the extractions were better than those made on the original sinter (table 17), but they were still unsatisfactory in the presence of $\mathrm{NaCl}$.

TABLE 18.-Extraction of annealed sinter $T_{\mathrm{a}}$ with solutions containing $210 \mathrm{~g}$ of sodium carbonate per liter and various amounts of sodium chloride

[Molar ratio of $\mathrm{Na}_{3} \mathrm{CO}_{3}$ in solution to $\mathrm{Al}_{2} \mathrm{O}_{3}$ in sinter $=2.0$. Weight of sinter per liter of extracting solution $=$ $561 \mathrm{~g}$. High-speed stirring]

\begin{tabular}{|c|c|c|c|c|}
\hline Experiment & $\begin{array}{l}\mathrm{NaCl} \text { in } \\
\text { extracting } \\
\text { solution }\end{array}$ & $\begin{array}{l}\text { Tempera- } \\
\text { ture of } \\
\text { extraction }\end{array}$ & $\begin{array}{l}\text { Time of } \\
\text { extraction }\end{array}$ & $\underset{\text { recovery }}{\mathrm{Al}_{2} \mathrm{O}_{2}}$ \\
\hline${ }^{2}{ }^{2}$ & $\begin{array}{r}\text { g/liter } \\
0 \\
100 \\
100 \\
0 \\
100\end{array}$ & $\begin{array}{r}{ }^{\circ} C \\
70 \\
70 \\
70 \\
80 \\
80\end{array}$ & $\begin{array}{r}\min \\
20 \\
10 \\
20 \\
10 \\
10\end{array}$ & $\begin{array}{r}\% \\
82.7 \\
76.5 \\
76.7 \\
79.6 \\
76.0\end{array}$ \\
\hline
\end{tabular}

However, annealing caused a considerable improvement in extractions of alumina at $70^{\circ} \mathrm{C}$ from sinter $\mathrm{R}_{\mathrm{a}}$, as shown by comparison of tables 17 and 19. A corresponding improvement resulted from the annealing of sinter $\mathrm{T}_{\mathrm{a}}^{\prime}$. Furthermore, the extractions of alumina from both sinters were not seriously affected by high concentrations of sodium chloride when the molar ratio of sodium carbonate in the solutions to alumina in the sinters was increased from 2.0 to 2.5 .

The extractions shown in table 19 were unexpectedly large, especially for sinter $R_{a}$, which even before annealing contained very little beta-dicalcium silicate and glass. It is known, however, that dicalcium silicate forms extensive solid solutions with various oxides, and a possible cause of the increased extractions might be the elimination of calcium aluminate from solid solution in dicalcium silicate. Such ex-solution would be favored by annealing. Rankin and Wright in

TABLE 19.-Extractions at $70^{\circ} C$ of annealed sinters, $R_{\mathrm{a}}$ and $T_{\mathrm{s}}^{\prime}$, with solution containing $210 \mathrm{~g}$ of sodium carbonate per liter and various amounts of sodium chloride

[High-speed stirring]

\begin{tabular}{|c|c|c|c|c|c|c|c|}
\hline $\begin{array}{c}\text { Experi- } \\
\text { ment }\end{array}$ & Sinter & $\begin{array}{l}\text { Quantity } \\
\text { of sinter } \\
\text { extracted }\end{array}$ & $\begin{array}{c}\text { Molar ratio } \\
\text { of } \mathrm{Na}_{2} \mathrm{CO}_{3} \\
\text { in solution } \\
\text { to } \mathrm{Al}_{2} \mathrm{O}_{3} \\
\text { in sinter }\end{array}$ & $\begin{array}{l}\mathrm{NaCl} \text { in } \\
\text { extracting } \\
\text { solution }\end{array}$ & $\begin{array}{c}\text { Time of } \\
\text { extraction }\end{array}$ & $\begin{array}{c}\mathrm{Al}_{2} \mathrm{O}_{3} \\
\text { recovery }\end{array}$ & $\begin{array}{l}\frac{\mathrm{SiO}_{2}}{\mathrm{Al}_{2} \mathrm{O}_{3}} \times 100 \\
\text { in solution }\end{array}$ \\
\hline & $\begin{array}{l}\mathrm{R}_{\mathrm{a}} \\
\mathrm{R}_{\mathrm{a}} \\
\mathrm{R}_{\mathrm{a}} \\
\mathrm{T}_{\mathrm{a}}^{\prime} \\
\mathrm{T}_{\mathrm{T}}^{\mathrm{s}}{ }_{\mathrm{s}}\end{array}$ & $\begin{array}{r}\text { glliter } \\
550 \\
550 \\
550 \\
571 \\
571\end{array}$ & $\begin{array}{l}2.0 \\
2.0 \\
2.0 \\
2.0 \\
2.0\end{array}$ & $\begin{array}{r}\text { glliter } \\
0 \\
100 \\
200 \\
0 \\
100\end{array}$ & $\min \begin{array}{r}10 \\
10 \\
10 \\
10 \\
10\end{array}$ & $\begin{array}{l}\%_{93.5} \\
89.6 \\
83.9 \\
90.2 \\
86.6\end{array}$ & $\begin{array}{l}2.48 \\
1.91 \\
1.54 \\
2.41 \\
2.17\end{array}$ \\
\hline $\begin{array}{l}6 \ldots . . \\
7 \ldots \\
8 \ldots \\
9 \ldots \\
10 \ldots\end{array}$ & $\begin{array}{l}T_{\mathrm{s}} \\
\mathrm{R}_{\mathrm{s}} \\
\mathrm{R}_{\mathrm{s}} \\
\mathrm{R}_{\mathrm{s}} \\
\mathrm{R}_{\mathrm{s}}\end{array}$ & $\begin{array}{l}571 \\
440 \\
440 \\
440 \\
440\end{array}$ & $\begin{array}{l}2.0 \\
2.5 \\
2.5 \\
2.5 \\
2.5\end{array}$ & $\begin{array}{r}200 \\
0 \\
100 \\
200 \\
200\end{array}$ & $\begin{array}{l}10 \\
10 \\
10 \\
10 \\
20\end{array}$ & $\begin{array}{l}81.0 \\
92.9 \\
92.4 \\
90.4 \\
90.2\end{array}$ & $\begin{array}{l}1.51 \\
2.96 \\
1.89 \\
1.21 \\
1.34\end{array}$ \\
\hline $\begin{array}{l}11 \ldots . \\
12 . . . \\
13 . . . \\
14 \ldots \\
15 \ldots\end{array}$ & $\begin{array}{l}\mathrm{R}_{\mathrm{s}}^{\mathrm{s}} \\
\mathrm{T}^{\prime} \\
\mathrm{T}^{\prime} \mathrm{s} \\
\mathrm{T}^{\prime} \mathrm{s} \\
\mathrm{T}_{\mathrm{s}}^{\prime} \\
\mathrm{s}\end{array}$ & $\begin{array}{l}440 \\
457 \\
457 \\
457 \\
457\end{array}$ & $\begin{array}{l}2.5 \\
2.5 \\
2.5 \\
2.5 \\
2.5\end{array}$ & $\begin{array}{r}200 \\
0 \\
100 \\
200 \\
200\end{array}$ & $\begin{array}{l}30 \\
10 \\
10 \\
10 \\
20\end{array}$ & $\begin{array}{l}92.9 \\
94.6 \\
94.4 \\
92.9 \\
92.2\end{array}$ & $\begin{array}{l}1.50 \\
2.39 \\
1.49 \\
1.09 \\
1.23\end{array}$ \\
\hline 16. & $T_{s-}^{\prime}$ & 457 & 2.5 & 200 & 30 & 89.8 & 1. 33 \\
\hline
\end{tabular}


TABLE 20.-Compositions of extracts and washes from extractions of annealed sinters, with solutions containing $210 \mathrm{~g}$ of sodium carbonate per liter and various amounts of sodium chloride

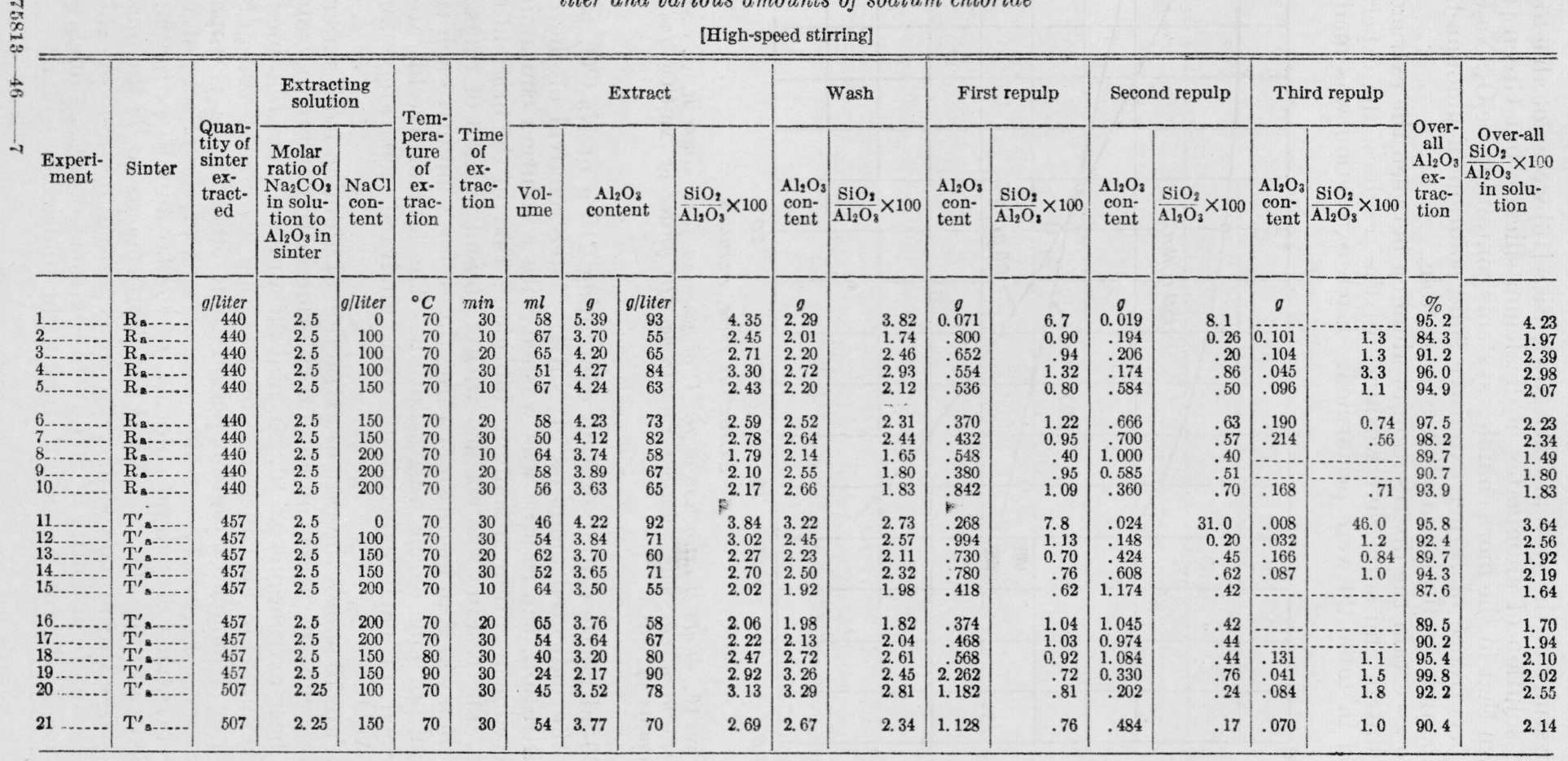


their study of the system $\mathrm{CaO}-\mathrm{Al}_{2} \mathrm{O}_{3}-\mathrm{SiO}_{2}[16]$ were not able to detect solid solution of aluminates in dicalcium silicate, but Green [17] has shown that in the more complex systems containing $\mathrm{Fe}_{2} \mathrm{O}_{3}, \mathrm{Na}_{2} \mathrm{O}$, etc., the occurrence of rather extensive solid solution of alumina-bearing compounds in dicalcium silicate is possible.

To ascertain the distribution of alumina between the extracts from the sinters and successive washings of the residues, the experiments listed in table 20 were performed. Each extraction was made with

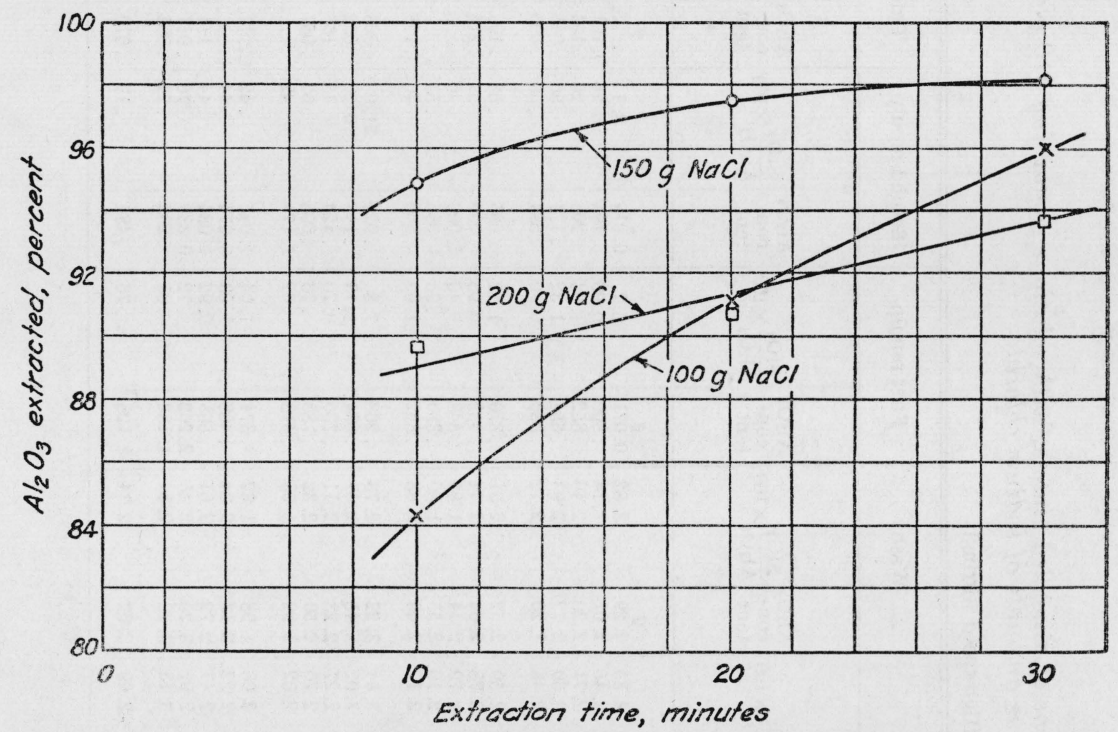

Figure 16.-Rate of extraction at $70^{\circ} C$ of alumina from sinter $R_{\mathrm{a}}(i$. e., sinter $R$ after annealing) with solutions containing $210 \mathrm{~g} /$ liter of $\mathrm{Na}_{2} \mathrm{CO}_{3}$ and various amounts of $\mathrm{NaCl}$.

a $100-\mathrm{ml}$ portion of a solution containing $210 \mathrm{~g}$ of $\mathrm{Na}_{2} \mathrm{CO}_{3}$ per liter and the indicated amounts of $\mathrm{NaCl}$. After removal of the extract by filtration, the residue was washed with a solution containing the same concentration of sodium chloride as that in the original extraction. The residue was washed with a $100-\mathrm{ml}$ portion of the solution and then was repulped two or three times, for 3 minutes each time, in $200-\mathrm{ml}$ portions of the wash solution. The four or five filtrates thus obtained in each experiment were analyzed separately for $\mathrm{SiO}_{2}$ and $\mathrm{Al}_{2} \mathrm{O}_{3}$.

Figure 16 shows the rate of extraction of alumina from sinter $R_{a}$ at various concentrations of sodium chloride in the extracting solutions. The best extractions at 10,20, and 30 minutes were obtained when the sodium chloride concentration was $150 \mathrm{~g} /$ liter. At $100 \mathrm{~g}$ of $\mathrm{NaCl}$ per liter a longer extraction period than 30 minutes is apparently necessary. Figure 17 permits comparisons of the effects of various concentrations of sodium chloride on the 30 minute extractions. A concentration of $150 \mathrm{~g}$ of $\mathrm{NaCl}$ per liter appears to be the optimum, and above this a marked decrease in extraction occurs. As shown in this figure, the quantity of $\mathrm{SiO}_{2}$ in the extracts decreases linearly with increase in the $\mathrm{NaCl}$ concentration of the solutions. 
Extraction of sinter $\mathrm{R}_{\mathrm{a}}$ with $\mathrm{Na}_{2} \mathrm{CO}_{3}-\mathrm{NaCl}$ solution of suitable concentration thus has a twofold advantage over extraction with $\mathrm{Na}_{2} \mathrm{CO}_{3}$ solution alone, in increasing the quantity of $\mathrm{Al}_{2} \mathrm{O}_{3}$ dissolved and decreasing that of $\mathrm{SiO}_{2}$. If it is assumed that $\mathrm{SiO}_{2}$ and $\mathrm{Al}_{2} \mathrm{O}_{3}$ will. be removed from solution in approximately equal percentages during desilication, the net recoveries of alumina in experiments 1 (no $\mathrm{NaCl}$ ) and 7 ( $150 \mathrm{~g}$ of $\mathrm{NaCl}$ per liter), table 20 , will be 91 and 96 percent, respectively.

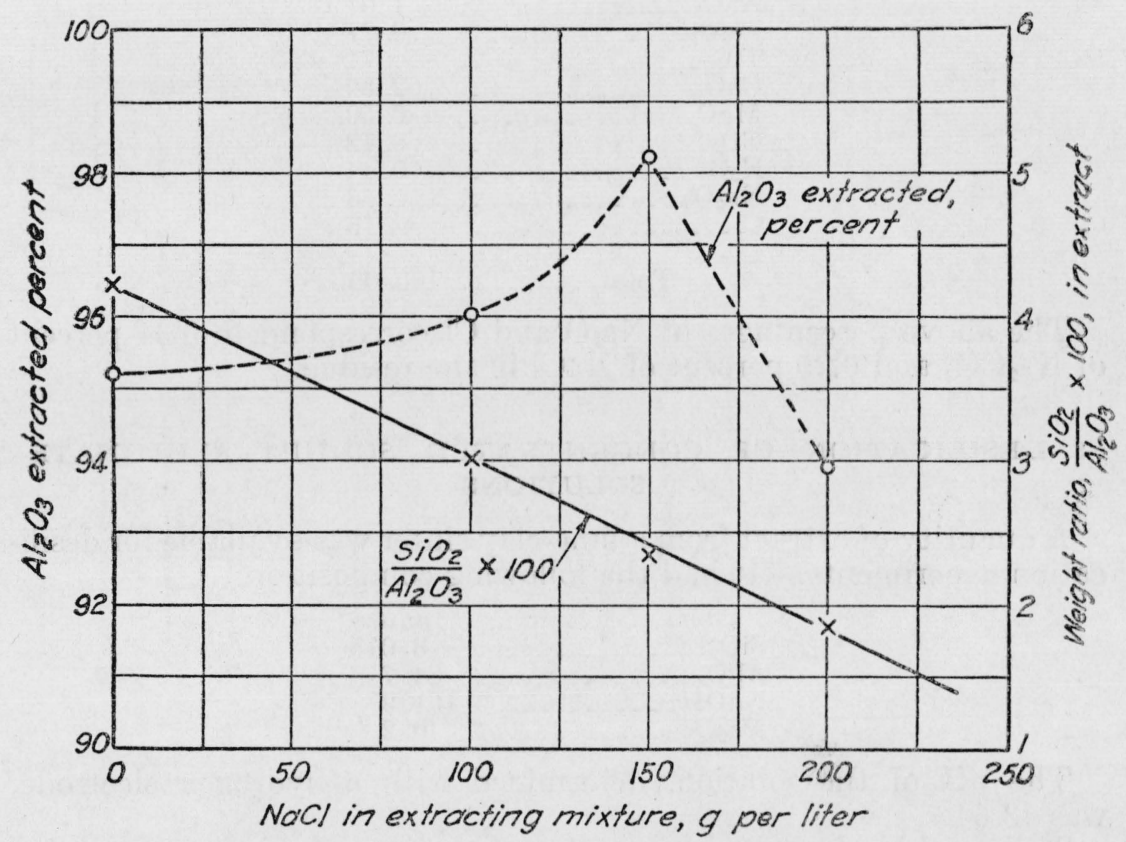

FIgURE 17.-Effect of sodium chloride on recovery of $\mathrm{Al}_{2} \mathrm{O}_{3}$ and on silica-alumina ratio in extracts from sinter $R_{\mathrm{a}}$.

Initial solutions contain $210 \mathrm{~g} /$ liter of $\mathrm{Na}_{2} \mathrm{CO}_{3}$ and various amounts of $\mathrm{NaCl}$. Extraction temperature= $70^{\circ} \mathrm{C}$; time $=10 \mathrm{~min}$

A slight disadvantage of the use of sodium chloride is the reduction it causes in the $\mathrm{Al}_{2} \mathrm{O}_{3}$ contents of the extracts. Thus, with 0 and $150 \mathrm{~g}$ of $\mathrm{NaCl}$ per liter in the initial solutions, the concentrations of $\mathrm{Al}_{2} \mathrm{O}_{3}$ in the extracts from sinter $\mathrm{R}_{\mathrm{a}}$ are 93 and $82 \mathrm{~g}$ of $\mathrm{Al}_{2} \mathrm{O}_{3}$ per liter, respectively. The corresponding values for sinter $\mathrm{T}_{\mathrm{a}}^{\prime}$ are 92 and $71 \mathrm{~g}$ of $\mathrm{Al}_{2} \mathrm{O}_{3}$ per liter, respectively.

The extractions of $\mathrm{Al}_{2} \mathrm{O}_{3}$ from sinters $\mathrm{R}_{\mathrm{a}}$ and $\mathrm{T}_{\mathrm{a}}^{\prime}$ are practically identical in the absence of $\mathrm{NaCl}$, but most of the extractions of sinter $\mathrm{T}^{\prime}{ }_{\mathrm{s}}$ with $\mathrm{Na}_{2} \mathrm{CO}_{3}-\mathrm{NaCl}$ solutions are several percent less than those of sinter $R_{a}$. In order to determine the effect of increased temperature, extractions of sinter $\mathrm{T}^{\prime}{ }_{\mathrm{s}}$ were made at $80^{\circ}$ and $90^{\circ} \mathrm{C}$ (experiments 18 and 19). At $90^{\circ} \mathrm{C}$ practically all the $\mathrm{Al}_{2} \mathrm{O}_{3}$ in the sinter was obtained in solution. The volumes of the extracts obtained at the higher temperatures were considerably less than those at $70^{\circ} \mathrm{C}$.

Extractions 20 and 21 were made using a molar ratio of $\mathrm{Na}_{2} \mathrm{CO}_{3}$ in solution to $\mathrm{Al}_{2} \mathrm{O}_{3}$ in the sinter of 2.25 instead of 2.5. Comparison of 
corresponding extractions shows that the lower molar ratio is satisfactory at $100 \mathrm{~g}$ of $\mathrm{NaCl}$ per liter in the initial solution but not at $150 \mathrm{~g}$ of $\mathrm{NaCl}$ per liter.

An analysis was made of the residue from extraction 4 after washing with hot water and drying at $110^{\circ} \mathrm{C}$. The following values were obtained:

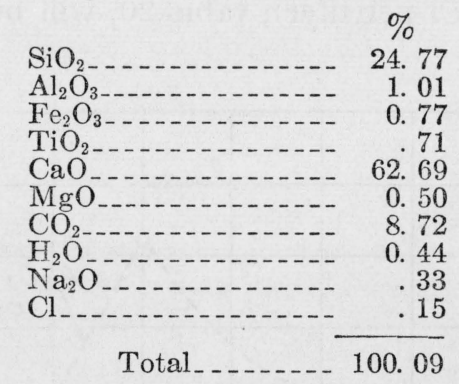

The above percentages of $\mathrm{Na}_{2} \mathrm{O}$ and $\mathrm{Cl}$ correspond to 0.34 percent of $\mathrm{Na}_{2} \mathrm{CO}_{3}$ and 0.25 percent of $\mathrm{NaCl}$ in the residue.

\section{DESILICATION OF CONCENTRATED SODIUM ALUMINATE SOLUTIONS}

A quantity of extract from a lime-clay sinter was available for desilication experiments. It had the following composition:

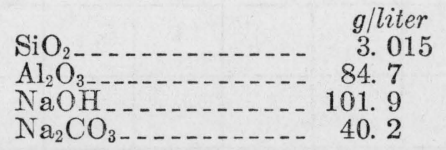

The $\mathrm{pH}$ of the solution, determined with a hydrogen electrode, was 13.64 .

Sodium chloride was added to $500-\mathrm{ml}$ portions of this extract to give 100,150 , and $200 \mathrm{~g}$ of $\mathrm{NaCl}$ per liter of solution. These portions and like volumes of the original extract were placed in iron containers fitted with reflux condensers and each solution was boiled for 2 hours with various amounts of synthetic sodalite prepared from dehydrated kaolin. Analyses of the resulting solutions for $\mathrm{SiO}_{2}$ and $\mathrm{Al}_{2} \mathrm{O}_{3}$ gave the values shown in table 21 .

TABLE 21.-Desilication of concentrated sodium aluminate extract containing various amounts of sodium chloride, by boiling for $2 \mathrm{hr}$ with synthetic sodalite

\begin{tabular}{|c|c|c|c|c|c|}
\hline \multirow{2}{*}{ Experiment } & \multirow{2}{*}{$\begin{array}{l}\mathrm{NaCl} \text { in } \\
\text { solution }\end{array}$} & \multirow{2}{*}{$\begin{array}{l}\text { Sodalite } \\
\text { added as } \\
\text { seed }\end{array}$} & \multicolumn{3}{|c|}{$\begin{array}{l}\text { Composition of solution after } \\
\text { desilication }\end{array}$} \\
\hline & & & $\mathrm{SiO}_{2}$ & $\mathrm{Al}_{2} \mathrm{O}_{3}$ & $\frac{\mathrm{SiO}_{2}}{\mathrm{Al}_{2} \mathrm{O}_{3}} \times 100$ \\
\hline $\begin{array}{l}1 \\
2 \\
3 \\
4 \\
5 \\
6 \\
7\end{array}$ & $\begin{array}{r}\text { g/liter } \\
0 \\
100 \\
150 \\
200 \\
200 \\
200 \\
200\end{array}$ & $\begin{array}{r}\text { g/liter } \\
10 \\
10 \\
10 \\
0 \\
10 \\
20 \\
50\end{array}$ & $\begin{array}{r}\text { g/llter } \\
0.344 \\
.211 \\
.220 \\
.371 \\
.139 \\
.081 \\
.040\end{array}$ & $\begin{array}{r}\text { g/liter } \\
81.4 \\
81.1 \\
81.1 \\
80.7 \\
80.9 \\
81.0 \\
80.9\end{array}$ & $\begin{array}{l}0.42 \\
.26 \\
.27 \\
.46 \\
.17 \\
.10 \\
.05\end{array}$ \\
\hline
\end{tabular}


Although the desilication improved as the sodium chloride concentration increased, undesirably large amounts of silica remained dissolved when the quantity of seed used was $10 \mathrm{~g} /$ liter of solution. It was thought that this amount of seed might be insufficient in view of the large amount of silica in the extract. To eliminate the silica completely from $500 \mathrm{ml}$ of solution would require the precipitation of $8.1 \mathrm{~g}$ of sodalite. Accordingly, the amount of seed was increased to 20 and $50 \mathrm{~g} /$ /iter in experiments 6 and 7 , respectively, and improved desilications were obtained.

In experiment 4 , the extract containing $200 \mathrm{~g}$ of $\mathrm{NaCl}$ per liter was boiled without the addition of seed. The precipitate that was formed was separated by filtration, washed with alcohol and ether, and examined microscopically. It was composed entirely of very small isotropic crystals having an index of refraction close to that of sodalite. Analysis gave the following composition expressed in molar ratios: $1.03 \mathrm{Na}_{2} \mathrm{O}: 1.00 \mathrm{Al}_{2} \mathrm{O}_{3}: 1.67 \mathrm{SiO}_{2}: 0.23 \mathrm{NaCl}: 3.06 \mathrm{H}_{2} \mathrm{O}$. The composition of this precipitate differs considerably from the theoretical proportions of sodalite, $\mathrm{Na}_{2} \mathrm{O} . \mathrm{Al}_{2} \mathrm{O}_{3} \cdot 2 \mathrm{SiO}_{2} \cdot 0.67 \mathrm{NaCl}$. If the material precipitated in the presence of seed shows a corresponding departure from the composition of sodalite, it might be anticipated that the seed charge would become less effective as it is used in successive desilications.

To determine whether such deterioration occurs, the experiments recorded in table 22 were carried out. The same desilication procedure as before was followed, using $500-\mathrm{ml}$ portions of the extract containing $100 \mathrm{~g}$ of $\mathrm{NaCl}$. In the first cycle, $25 \mathrm{~g}$ of sodalite was used. The sodalite recovered after this desilication was washed with hot water, alcohol, and ether, and dried in air. A 25-g charge of this material was then used for desilication of a second batch of solution. The same procedure was repeated in a third desilication.

The original sodalite had a composition corresponding to the following molar ratios: $0.99 \mathrm{Na}_{2} \mathrm{O}: 1.00 \mathrm{Al}_{2} \mathrm{O}_{3}: 2.01 \mathrm{SiO}_{2}: 0.61 \mathrm{NaCl}: 0.54 \mathrm{H}_{2} \mathrm{O}$. After this material had been used in three successive desilications, as indicated in table 22, it was reanalyzed and the following molar ratios obtained: $1.00 \mathrm{Na}_{2} \mathrm{O}: 1.00 \mathrm{Al}_{2} \mathrm{O}_{3}: 2.04 \mathrm{SiO}_{2}: 0.56 \mathrm{NaCl}: 1.96 \mathrm{H}_{2} \mathrm{O}$. Thus, it appears that the material precipitated in the presence of seed has very nearly the theoretical composition of sodalite. However, a slight decrease in $\mathrm{NaCl}$ content and increase in water of hydration of the mixture of seed and precipitate had occurred.

It seemed possible that the sodium chloride content of the sodalite, and also its desilication efficiency, might be restored by treating the

TABLE 22.-Effectiveness of sodalite on repeated use for desilicating a concentrated sodium aluminate solution (cycles 1, 2, and 3), and the subsequent improvement caused by boiling the used sodalite for $2 \mathrm{hr}$ with a solution saturated with $\mathrm{NaCl}$ (cycle 4)

[Volume of sodium aluminate solution, containing $100 \mathrm{~g}$ of $\mathrm{NaCl}, 500 \mathrm{ml}$; quantity of sodalite, $25 \mathrm{~g}$; time of boiling, 2 hr.]

\begin{tabular}{|c|c|}
\hline Cycle & $\begin{array}{c}\frac{\mathrm{SiO}_{2}}{\mathrm{Al}_{2} \mathrm{O}_{3}} \\
\text { desilicated } \\
\text { solution }\end{array}$ \\
\hline 1 & 0.053 \\
2 & .067 \\
3 & .080 \\
4 & .037 \\
\hline
\end{tabular}


used preparation with sodium chloride solution. Accordingly, the seed charge recovered from cycle 3, table 22, was boiled for 2 hours with a saturated salt solution, and $25 \mathrm{~g}$ of this product was used to desilicate another batch of extract. As shown in table 22, the seed charge than gave a more effective desilication than the original sodalite.

The desilications recorded in table 23 were made on duplicates of extracts, having the same numbers, listed in table 20 . These extracts, in volumes of 120 to $150 \mathrm{ml}$, were boiled with synthetic sodalite, in the proportion of $25 \mathrm{~g} / \mathrm{liter}$ of solution. It was found to be advantageous to disperse the sodalite in the extracts by high-speed stirring before boiling.

All of the desilicated extracts (table 23) are sufficiently low in silica and high in alumina to permit differential precipitation of alumina containing about 0.02 percent of silica, according to the method described by McCulloch [7].

TABLE 23.-Desilication of extracts from sinters $R_{\mathrm{B}}$ and $T^{\prime}{ }_{\mathrm{a}}$, by boiling with synthetic sodalite

[Sodalite, $25 \mathrm{~g} /$ liter]

\begin{tabular}{|c|c|c|c|c|c|c|}
\hline \multirow{2}{*}{ Experiment } & \multirow{2}{*}{ Sinter } & \multirow{2}{*}{$\begin{array}{l}\mathrm{NaCl} \text { in } \\
\text { extracting } \\
\text { solution }\end{array}$} & \multirow{2}{*}{$\begin{array}{c}\mathrm{Al}_{2} \mathrm{O}_{3} \text { in } \\
\text { extract }\end{array}$} & \multirow{2}{*}{$\begin{array}{c}\text { Time of } \\
\text { boiling for } \\
\text { desilication }\end{array}$} & \multicolumn{2}{|c|}{$\frac{\mathrm{SiO}_{2}}{\mathrm{Al}_{2} \mathrm{O}_{3}} \times 100$ in extract } \\
\hline & & & & & $\begin{array}{l}\text { Before de- } \\
\text { silication }\end{array}$ & $\begin{array}{l}\text { After de- } \\
\text { silication }\end{array}$ \\
\hline 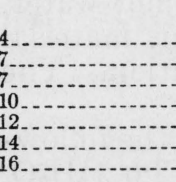 & 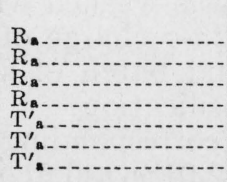 & $\begin{array}{r}\text { g/liter } \\
100 \\
150 \\
150 \\
200 \\
100 \\
150 \\
200\end{array}$ & $\begin{array}{r}\text { g/liter } \\
84 \\
82 \\
82 \\
65 \\
71 \\
71 \\
58\end{array}$ & $\begin{array}{r}h r \\
2 \\
1 \\
2 \\
2 \\
1 \\
1 \\
2\end{array}$ & $\begin{array}{l}3.30 \\
2.78 \\
2.78 \\
2.17 \\
3.02 \\
2.70 \\
2.06\end{array}$ & $\begin{array}{l}0.10 \\
.082 \\
.077 \\
.057 \\
.15 \\
.085 \\
.060\end{array}$ \\
\hline
\end{tabular}

\section{THEORY OF SODALITE DESILICATION}

It has been shown that desilication of a sodium aluminate solution is favored by the following factors: (1) The presence of a high concentration of sodium chloride in the solution, (2) the presence or formation of a seed charge of sodalite, (3) a boiling temperature at atmospheric pressure or higher temperatures and pressures, and (4) sufficient time for precipitation of sodalite to approach completion.

In the initial extraction of the lime-clay sinters, the above conditions must be avoided, insofar as possible, to prevent losses of soda and alumina that would result from formation of sodalite at this stage. Because economical operation of the process requires a high concentration of sodium chloride in the extracting solution, the precipitation of sodalite is prevented by using a short extraction time at a temperature below boiling, and with the exclusion of material that might serve as seed.

Sodalite liberates sodium chloride to solution when in contact with boiling water [6] and thus is incongruently soluble. The end product resulting from complete liberation of the sodium chloride in sodalite is probably the comparatively soluble hydrated sodium aluminum silicate formed in the Bayer process. At high concentrations of sodium chloride in solution, the solubility of sodalite becomes increas- 
ingly congruent and diminishes to very low values. Sodium hydroxide, however, has an effect opposite to that of sodium chloride, and sodalite becomes less stable as the alkalinity of the solution rises.

The function of the seed charge during desilication is to induce the precipitation of crystalline sodalite. As shown in the preceding section, the material precipitated from solution in the absence of seed has a composition differing considerably from that of sodalite but, when seed is present, the precipitate has very nearly the theoretical composition.

\section{FLOW SHEET AND SUMMARY OF PROCESS}

A suggested commercial process for the extraction of alumina from clay, by the lime-sinter method developed in this study, is shown in figure 18.

The composition of the clay given in the flow sheet is that of a kaolin used in this investigation. Minor constituents of the kaolin are omitted in order to simplify the diagram. A mixture of clay and limestone is prepared by either wet or dry process grinding and mixing. The composition of the resulting material on an ignited basis should correspond approximately to a point on the line joining $2 \mathrm{CaO}^{-\mathrm{SiO}_{2}}$ and the quintuple point $\mathrm{CaO} \cdot \mathrm{Al}_{2} \mathrm{O}_{3}, 5 \mathrm{CaO} .3 \mathrm{Al}_{2} \mathrm{O}_{3}$, and $2 \mathrm{CaO} \cdot \mathrm{SiO}_{2}$ in the $\mathrm{CaO}-\mathrm{Al}_{2} \mathrm{O}_{3}-\mathrm{SiO}_{2}$ diagram. Allowance is made for the lime and alumina required for the formation of $\mathrm{CaO} . \mathrm{TiO}_{2}, 4 \mathrm{CaO} \cdot \mathrm{Al}_{2} \mathrm{O}_{3} \cdot \mathrm{Fe}_{2} \mathrm{O}_{3}$, or $\mathrm{Na}_{2} \mathrm{O} \cdot \mathrm{Al}_{2} \mathrm{O}_{3}$ with any $\mathrm{TiO}_{2}, \mathrm{Fe}_{2} \mathrm{O}_{3}$, or $\mathrm{Na}_{2} \mathrm{O}$ in the raw materials.

The equipment described by McLarmour, McMaster, and Jacques [18] appears to be particularly well adapted for burning the raw mix and annealing the resulting clinker. This apparatus consists of an ordinary rotary kiln in series with a rotary cooler carrying a burner installed at its feed end. The clinker discharged from the primary kiln can be annealed in the cooler at a rate determined by its speed of rotation and by adjustment of the burner.

Complete dusting of the annealed clinker obviates the need of grinding. The material is extracted for about one-half hour at 60 to $80^{\circ} \mathrm{C}$ with a solution containing approximately $200 \mathrm{~g}$ of $\mathrm{Na}_{2} \mathrm{CO}_{3}$ and $150 \mathrm{~g}$ of $\mathrm{NaCl}$ per liter. High-speed stirring of the slurry is used.

On completion of the extraction period, the mixture is filtered and an extract containing 70 to $80 \mathrm{~g}$ of $\mathrm{Al}_{2} \mathrm{O}_{3}$ and 1 to $2 \mathrm{~g}$ of $\mathrm{SiO}_{2}$ per liter is obtained. By subjecting the residue to counter-current washing with salt solution, it is anticipated that the concentration of $\mathrm{Al}_{2} \mathrm{O}_{3}$ in the wash water can be built up to approach that in the extract. The residue may then be washed with water and stock-piled as a raw material for the manufacture of portland cement.

The solution, plus concentrated washings, is next desilicated by boiling it for 1 hour with a seed charge of synthetic sodalite (25 $\mathrm{g} /$ liter of solution). After filtration, the sodalite in excess of that required for seed for the next batch is returned to the first stage of the process, allowance for its addition being made in calculation of the amount of limestone to be used in the subsequent batch. By this means, the alumina and soda in the excess sodalite are recovered.

Alumina is precipitated as gibbsite by passing carbon dioxide into the desilicated solution. Scrubbed gases from the kiln are the source of carbon dioxide. In order to avoid contamination by silica, the precipitation of alumina is not carried to completion. However, in 


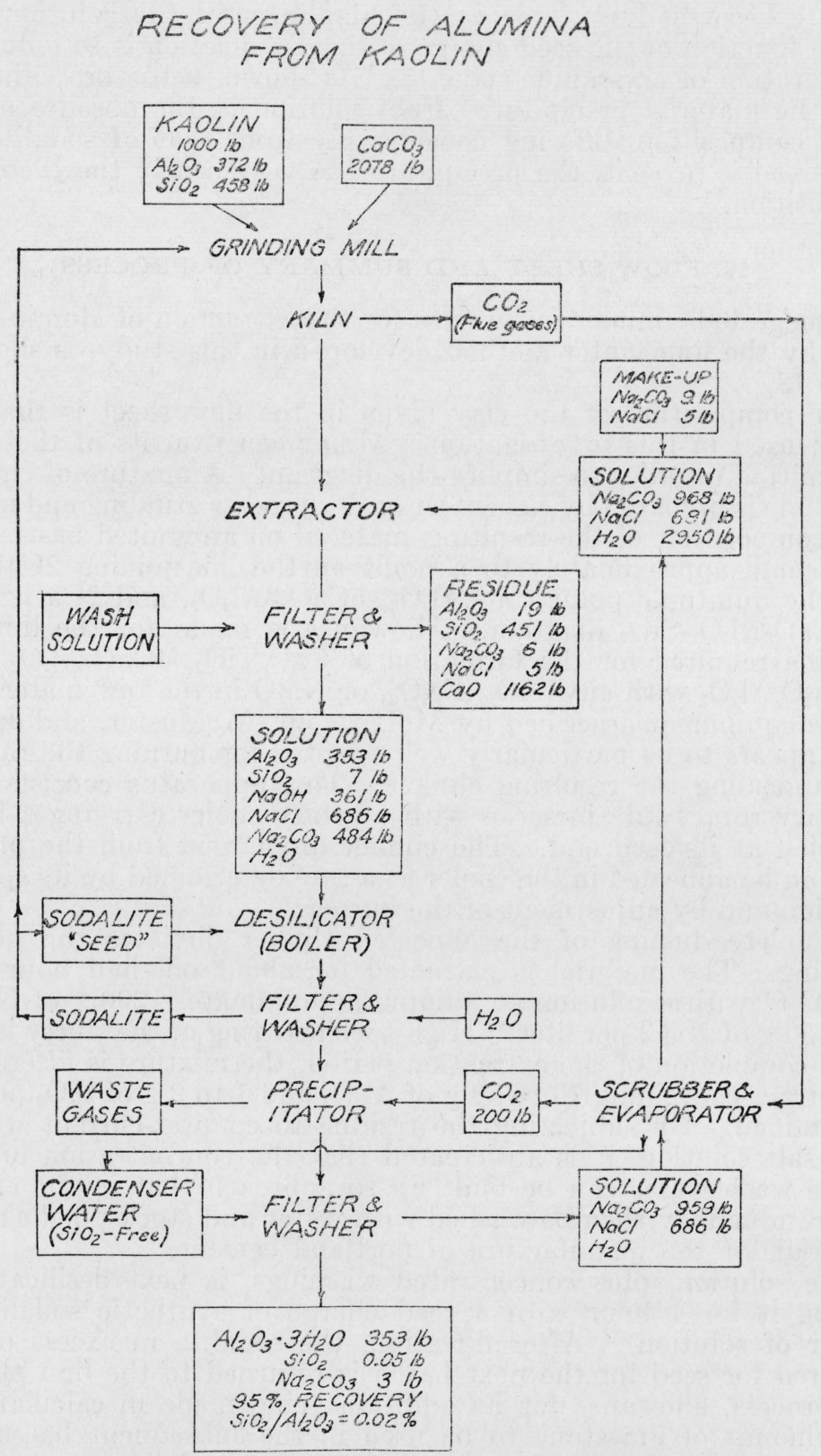

FIGURE 18.-Flow sheet of suggested process for extracting alumina from kaolin. 
cyclical operation of the process, complete recovery of the alumina from solution would be obtained and this is indicated in the flow sheet. The hydrated alumina is filtered and washed with water, low in silica to avoid contamination. The residual solution and the washings are used to scrub the kiln-flue gases. This procedure effects evaporation of water from the combined solution and washings, and dust is removed from the gases. Make-up quantities of sodium carbonate and sodium chloride are added to the evaporated and carbonated solution, which is then used for extraction of a fresh batch of sinter. The precipitated gibbsite is dried and calcined for electrolytic reduction to aluminum.

\section{EXTRACTION OF ALUMINA FROM HIGH-SILICA BAUXITES BY THE LIME-SINTER PROCESS}

\section{MATERIALS}

Bauxite B, the composition of which is given in table 1, was selected for study. Other experiments were made on a diaspore bauxite (bauxite E) having the following composition:

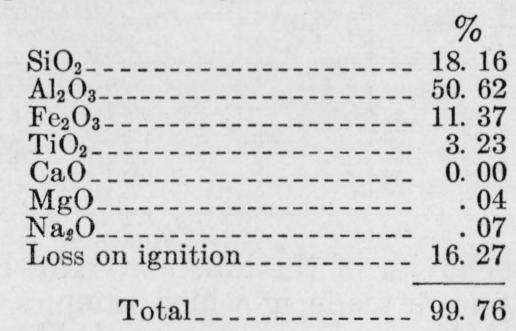

The major part of the iron oxide content of this material was in the ferrous state, as siderite.

Other materials included calcium carbonate, sodium carbonate, sodium chloride, and sodium hydroxide.

\section{PROCEDURE, RESULTS, AND DISCUSSION}

Calcium carbonate-bauxite mixtures were prepared which, after burning, would contain $\mathrm{Al}_{2} \mathrm{O}_{3}$ as $\mathrm{CaO} . \mathrm{Al}_{2} \mathrm{O}_{3}, 5 \mathrm{CaO} .3 \mathrm{Al}_{2} \mathrm{O}_{3}$, and $4 \mathrm{CaO}$.$\mathrm{Al}_{2} \mathrm{O}_{3} \cdot \mathrm{Fe}_{2} \mathrm{O}_{3}$; $\mathrm{SiO}_{2}$ as $2 \mathrm{CaO} . \mathrm{SiO}_{2}$; and $\mathrm{TiO}_{2}$ as $\mathrm{CaO}$. TiO 2 . The mixture made from bauxite $\mathrm{B}$, in $100 \mathrm{-g}$ batches, was heated in an electric furnace at $1,300^{\circ} \mathrm{C}$ for 1 hour and cooled slowly, but without careful control of annealing temperatures. Complete dusting of the product occurred on cooling.

Extractions were made of the dusted sinter at $50^{\circ} \mathrm{C}$ for 2 hours, using a slow-speed shaking machine. Table 24 shows the recoveries of $\mathrm{Al}_{2} \mathrm{O}_{3}$ obtained after desilication of the extracts with sodalite. The highest extraction was obtained when the molar ratio of $\mathrm{Na}_{2} \mathrm{CO}_{3}$ in solution to $\mathrm{Al}_{2} \mathrm{O}_{3}$ in the sinter was 4.0. Small amounts of $\mathrm{NaOH}$ in the initial solutions had little effect on the extractions, but a concentration of $50 \mathrm{~g}$ of $\mathrm{NaOH}$ per liter (experiment 4) gave a greatly reduced recovery of $\mathrm{Al}_{2} \mathrm{O}_{3}$.

A sample of sinter $\mathrm{B}$ was reheated to $1,300^{\circ} \mathrm{C}$, in an electric furnace, held at that temperature for 1 hour, and cooled to $1,150^{\circ} \mathrm{C}$ at a uniform rate of 1 degree per minute. The dusted sinter was ex- 
tracted for $1 / 2$ hour at $70^{\circ} \mathrm{C}$ with a solution containing $50 \mathrm{~g}$ of $\mathrm{Na}_{2} \mathrm{CO}_{3}$ and $150 \mathrm{~g}$ of $\mathrm{NaCl}$ per liter, using high-speed stirring. The residue was washed by the multiple repulping procedure described previously. An over-all recovery of 97 percent of the $\mathrm{Al}_{2} \mathrm{O}_{3}$ in this sinter was obtained in solution and the over-all $\mathrm{SiO}_{2}$ was 1.22 percent. The recovery of $\mathrm{Al}_{2} \mathrm{O}_{3}$ is approximately the same as those obtained from sinters $\mathrm{R}_{\mathrm{a}}$ and ' $\mathrm{T}_{\mathrm{a}}$ ' under corresponding conditions.

A 3-pound batch of the mixture of calcium carbonate and bauxite $\mathrm{E}$ was burned in a gas-fired fumace at $1,300^{\circ} \mathrm{C}$ for 1 hour and cooled to $1,200^{\circ} \mathrm{C}$ in $1 \frac{1}{2}$ hours. The product, which failed to dust, was ground to pass a No. 200 sieve. Only 71 percent of the alumina in this sinter was obtained in solution by the procedure given in the preceding paragraph.

TABLE 24.-Extraciion at $50^{\circ} \mathrm{C}$ of lime sinter prepared from bauxite $B$ (84.6 g of sinter per liter of exiracting solution)

[Time of extraction, $2 \mathrm{hr}$ ]

\begin{tabular}{|c|c|c|c|c|c|c|}
\hline \multirow{2}{*}{ Experiment } & \multicolumn{3}{|c|}{ Composition of extracting solution } & \multirow{2}{*}{$\begin{array}{l}\text { Molar ratio } \\
\text { of } \mathrm{Na}_{2} \mathrm{CO}_{3} \\
\text { in solution } \\
\text { to } \mathrm{Al}_{2} \mathrm{O}_{3} \text { in } \\
\text { sinter }\end{array}$} & \multirow{2}{*}{$\begin{array}{l}\mathrm{Al}_{2} \mathrm{O}_{3} \text { on } \\
\text { recovery }\end{array}$} & \multirow{2}{*}{$\frac{\mathrm{SiO}_{2}}{\mathrm{Al}_{2} \mathrm{O}_{3}} \times 100$} \\
\hline & $\mathrm{Na}_{2} \mathrm{CO}_{3}$ & $\mathrm{NaOH}$ & $\mathrm{NaCl}$ & & & \\
\hline $\begin{array}{l}1 \\
2 \\
3 \\
3\end{array}$ & $\begin{array}{r}\text { g/liter } \\
38 \\
50 \\
99 \\
38\end{array}$ & $\begin{array}{r}\text { glliter } \\
5 \\
0 \\
5 \\
50\end{array}$ & $\begin{array}{r}\text { g/liter } \\
136 \\
179 \\
317 \\
297\end{array}$ & $\begin{array}{l}1.5 \\
2.0 \\
4.0 \\
1.5\end{array}$ & $\begin{array}{lr} & \\
& 76 \\
80 \\
84 \\
25\end{array}$ & $\begin{array}{r}0.03 \\
.07 \\
.04 \\
.09\end{array}$ \\
\hline
\end{tabular}

To compare the behavior of the lime sinters of bauxites $\mathrm{B}$ and $\mathrm{E}$, parallel experiments were made in which samples of the raw mixes were heated to $1,300^{\circ} \mathrm{C}$ in an electric furnace, held at that temperature for 1 hour, and cooled to $1,150^{\circ} \mathrm{C}$ at the rate of 2 degrees per minute. The sinter from bauxite B dusted completely, but that from bauxite $\mathrm{E}$ failed to dust. As both sinters contained approximately the same amount of $\mathrm{Fe}_{2} \mathrm{O}_{3}$, the difference in behavior was attributed to the presence of about 37 percent of dicalcium silicate in the bauxite B sinter as compared with 30 percent in that of bauxite $\mathrm{E}$.

It was concluded that bauxite $\mathrm{E}$ would have to be mixed with a material of higher silica content to obtain a sinter that would dust satisfactorily. For this purpose a mixture of 75 percent of bauxite $\mathrm{E}$ and 25 percent of kaolin (based on ignited weights) was prepared. A sample was heated in an electric furnace to $1,300^{\circ} \mathrm{C}$, held at that temperature for 1 hour, and cooled to $1,150^{\circ} \mathrm{C}$ at 1 degree per minute. The product, which contained about 41 percent of dicalcium silicate, dusted completely. Extractions, made as before, dissolved 88 percent of the $\mathrm{Al}_{2} \mathrm{O}_{3}$ from the sinter.

It is not known why the extractions of the bauxite $\mathrm{E}$ sinters are inferior to those of bauxite $\mathrm{B}$. Analysis of bauxite $\mathrm{E}$ for $\mathrm{P}_{2} \mathrm{O}_{5}$ and $\mathrm{Cr}_{2} \mathrm{O}_{3}$ showed only traces of these oxides, which, in small amounts, might prevent the complete beta-gamma inversion of dicalcium silicate.

The above experiments appear to indicate that the suitability of an aluminous ore, as a raw material for the extraction of alumina by the lime-sinter method, cannot be accurately predicted without actual laboratory tests. This is because of the numerous factors 
which affect the completeness of the beta-gamma inversion of dicalcium silicate, on which the success of the method depends. In general, it appears that annealing must be the more prolonged, the higher the proportion of fluxing oxides in the sinter and the lower the dicalcium silicate content. Sinters containing as little as 20 percent of dicalcium silicate can be made to dust, as shown by Lerch and Brownmiller [15], but a 17-hour annealing schedule was required.

\section{POSSIBLE COMMERCIAL SIGNIFICANCE OF METHODS}

The principal advantage of preparing sodium aluminate solutions by the method described in section II consists in the attainment of a more complete separation of alumina and silica than is given by the Bayer process. This fact makes it possible to precipitate a considerably greater proportion of alumina from the salt-containing extract than from the Bayer solution, before contamination of the precipitated alumina by silica becomes excessive.

In the recovery of soda and alumina from the "red-mud" residues, the use of an extracting solution containing sodium chloride permits the subsequent desilication to be carried out at atmospheric pressure rather than in autoclaves as has been the practice heretofore.

It is believed that the lime-sinter process developed in this study has considerable commercial promise, particularly as applied to clay, for the following reasons:

1. Recoveries of approximately 95 percent of the alumina in clay can be obtained from annealed lime-clay sinters. Such recoveries are comparable with those obtained by acid extraction of kaolin clays [10] and exceed values that have been reported for other alkaline processes [5].

2. Losses of alkali are small.

3. All steps of the process can be carried out at atmospheric pressure.

4. As shown in the flow sheet, the process is simple and no unusual equipment is required.

In common with other alkaline methods for the extraction of alumina from clay, this process suffers from the disadvantage of requiring calcination of the clay with somewhat more than twice its weight of limestone. Only large-scale operation will show whether the cost of this step will be sufficiently compensated by the factors listed above.

The authors are indebted to H. F. McMurdie, of this Bureau, for making the X-ray diffraction patterns of the sodalite-type compounds. Acknowledgment is also made to F. R. Archibald, Ancor Corporation, for the suggestion that high-speed stirring be used in the extraction of lime-clay sinters.

\section{REFERENCES}

[1] J. D. Edwards, F. C. Frary, and Z. Jeffries, The aluminum industry, I, 126 (McGraw-Hill Book Co., Inc., New York, N. Y., 1930).

[2] L. S. Wells, BS J. Research 1, 951-1009 (1928) RP34.

E. P. Flint and L. S. Wells, BS J. Research 12, 751-83 (1934) RP687.

L. S. W Wlls, W. F. Clarke, and H. F. McMurdie, J. Research NBS 30, 367409 (1943) RP1539. 
[3] W. C. Hansen, J. Am. Ceram. Soc. 11, 68 (1928).

T. Thorvaldson, N. S. Grace, and V. A. Vigfusson, Can. J. Research 1, 201-13 (1929).

[4] V. M. Pesin and I. S. Lileev, Russian patent 39,093, Oct. 31, 1934.

[5] F. N. Strokov, Trans. State Inst. Applied Chem. (U. S. S. R.) 29, 7-272 (1936); 33, 5603-5 (1939).

F. N. Strokov and coworkers, Sbornik Rabot Lab. Gosudarst. Inst. Prikladnoi Khim. 1940, No. 32, 1-199. Chem. Abstr. 37, 3885-8 (1943).

K. Kammermeyer and A. H. White, Trans. Am. Inst. Chem. Engrs. 36, 683-99 (1940).

W. D. Treadwell and H. Schneeberger, Helv. Chim. Acta 22, 1048-58 (1939).

[6] N. H. and A. N. Winchell, Elements of optical mineralogy, part 2, 3d ed., p. 289 (John Wiley \& Sons, Inc., New York, N. Y., 1933).

[7] G. McCulloch, U. S. Patent 941,799. Nov. 30, 1909.

[8] R. S. Dean, Mining and Metallurgy 24, 356-9 (1943). W. E. Trauffer, Pit and Quarry 36, 115-22, 140 (1944).

[9] Advisory Committee to WPB, Metal Progress 42, 197-200 (1942).

[10] R. Miller, A. W. Hixon, and A. L. Giorgi, Light Metal Age 1, no. 2, 6-7, 20, $22 ;$ no. 3, 14-15, 28, 30 (1943).

[11] S. J. Thugutt, Neues Jahrb. Mineral Beilage Bd. 9, 579 (1895).

[12] J. Lemberg, Z. deut. geol. Ges. 28, 601-3 (1875).

[13] J. Morozewicz, Tschermak's mineralog. petrog. Mitt. 18, 128 (1898).

[14] Z. Weyberg, Centr. Mineral Geol. 717 (1905).

[15] W. Lerch and L. T. Brownmiller, J. Research NBS 18, 609-22 (1937) RP997. W. Lerch and W. C. Taylor, Concrete, Cement Mill Ed., 45, 199, 217 (1937).

[16] G. A. Rankin and F. E. Wright, Am. J. Sci. [4] 39, 1-79 (1915).

N. L. Bowen and J. W. Greig, J. Am. Ceram. Soc. 1, 238 (1924).

[17] K. T. Grzene, J. Research NBS 32, 1-10 (1944) RP1570.

[18] H. McLarmour, E. L. McMaster, and W. Jacques, Rock Products 46, 59 (1943).

WASHINGTON, October 1, 1945. 